
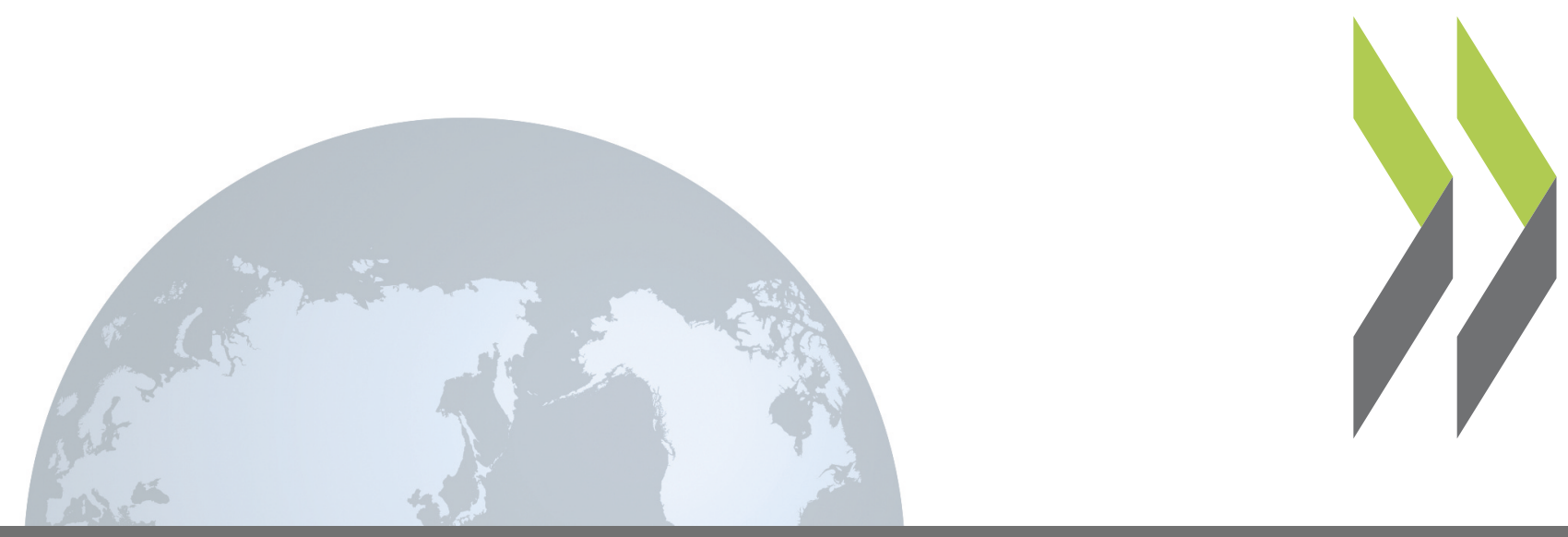

OECD Education Working Papers No. 121

\title{
Fostering social
}

\section{and emotional skills through}

families, schools

and communities: Summary

Hiroko Ikesako,

of international evidence Koji Miyamoto and implication for Japan's educational practices and research 
Organisation de Coopération et de Développement Économiques

Organisation for Economic Co-operation and Development

10-Jun-2015

DIRECTORATE FOR EDUCATION AND SKILLS

English - Or. English

\section{FOSTERING SOCIAL AND EMOTIONAL SKILLS THROUGH FAMILIES, SCHOOLS AND COMMUNITIES}

Summary of international evidence and implication for Japan's educational practices and research

By Hiroko Ikesako and Koji Miyamoto, OECD

OECD Education Working Paper no. 121

This Working Paper was prepared for the Education for Social Progress (ESP) project, with support from the Benesse Educational Research and Development Institute (BERD) in Japan.

This working paper has been authorised by Andreas Schleicher, Director of the Directorate for Education and Skills, OECD.

Hiroko Ikesako, Directorate for Education and Skills, OECD (hiorko.ikesako@oecd.org) Koji Miyamoto, Directorate for Education and Skills, OECD (koji.miyamoto@oecd.org)

JT03378287

Complete document available on OLIS in its original format

This document and any map included herein are without prejudice to the status of or sovereignty over any territory, to the delimitation of international frontiers and boundaries and to the name of any territory, city or area. 
OECD Working Papers should not be reported as representing the official views of the OECD or of its member countries. The opinions expressed and arguments employed herein are those of the authors.

Working Papers describe preliminary results or research in progress by the authors and are published to stimulate discussion on a broad range of issues on which the OECD works. Comments on Working Papers are welcome, and may be sent to the Directorate for Education and Skills, OECD, 2 rue André-Pascal, 75775 Paris Cedex 16, France.

This document and any map included herein are without prejudice to the status of or sovereignty over any territory, to the delimitation of international frontiers and boundaries and to the name of any territory, city or area.

You can copy, download or print OECD content for your own use, and you can include excerpts from OECD publications, databases and multimedia products in your own documents, presentations, blogs, websites and teaching materials, provided that suitable acknowledgment of the source and copyright owner is given. All requests for public or commercial use and translation rights should be submitted to rights@oecd.org. Requests for permission to photocopy portions of this material for public or commercial use shall be addressed directly to the Copyright Clearance Center (CCC) at info@copyright.com or the Centre français d'exploitation du droit de copie (CFC) at contact@cfcopies.com.

Comment on the series is welcome, and should be sent to edu.contact@oecd.org.

This working paper has been authorised by Andreas Schleicher, Director of the Directorate for Education and Skills, OECD. 


\begin{abstract}
Social and emotional skills, such as perseverance, sociability and self-esteem, help individuals face the challenges of the 21st century and benefit from the opportunities it brings. Policy makers, teachers and parents can help foster these skills by improving the learning environments in which they develop. This paper reviews international evidence, including those from Japan, to better understand the learning contexts that can be conducive to children's social and emotional development. It sheds light on features that underlie successful learning programmes including intervention studies. Reviewed evidence suggests that there are important roles for families, schools and communities to play in enhancing children's social and emotional skills, and that coherence across multiple learning contexts needs be ensured. While most of the evidence comes from the United States and the United Kingdom, the paper suggests that further efforts could be made in Japan in collecting and better exploiting micro-data on a range of social and emotional skills, as well as in evaluating effectiveness of interventions designed to raise social and emotional skills.
\end{abstract}

\title{
RÉSUMÉ
}

Les compétences socio-affectives, telles que la persévérance, la sociabilité et l'estime de soi, aident les individus à faire face aux défis du $\mathrm{XXI}^{\mathrm{e}}$ siècle et à tirer profit des opportunités qu'il offre. Les décideurs, les enseignants et les parents peuvent favoriser le développement de ces compétences en améliorant les environnements d'apprentissage au sein desquels se fait leur acquisition. Ce document examine les données internationales, notamment celles du Japon, afin de mieux identifier les cadres d'apprentissage susceptibles d'être propices à l'acquisition des compétences socio-affectives chez l'enfant. Il met au jour les caractéristiques sous-tendant la réussite des programmes d'apprentissage incluant des études d'intervention. L'analyse des données met en évidence le rôle important que peuvent jouer les familles, l'école et la collectivité dans le développement des compétences socio-affectives chez l'enfant, et la nécessité de garantir la cohérence entre les différents cadres d'apprentissage. Si la plupart des données viennent des États-Unis et du Royaume-Uni, ce document suggère que des efforts supplémentaires pourraient être faits au Japon pour collecter et mieux exploiter des micro-données sur un ensemble de compétences socio-affectives, ainsi que pour évaluer l'efficacité des interventions visant à renforcer ces compétences. 


\section{ACKNOWLEDGEMENT}

This paper was produced with support from the Benesse Educational Research and Development Institute (BERD), Japan. We would like to acknowledge invaluable inputs and assistance from Kenichi Arai, Noriko Goto, Chie Hoshi, Ito Kutsuzawa, Seiko Mochida, Reiko Nakata, Mieko Sanada, and Junko Takaoka. Special thanks go to Clemens Noelke (Harvard University), Takehisa Shinozaki (Waseda University), Masumi Sugawara (Ochanomizu University) and Yusuke Takahashi (Kyoto University), who provided extensive guidance and comments during preparation of the paper. We also thank Misako Aramaki (Mejiro University), Masakazu Hojo (Niigata University), Ayako Ito (Ochanomizu University), Reizo Koizumi (Fukuoka University of Education), Ikuko Shinohara (National Institute for Educational Policy Research), and Kayoko Watanabe (Aichi Shukutoku University), for their helpful advice. Finally, our thanks go to our colleagues from the OECD, María del Carmen Huerta for her valuable suggestions during the preparation of the paper, Masafumi Ishikawa, Katarzyna Kubacka, Elodie Isabel de Oliveira, and Mathilde Overduin for their comments on the draft, and Louise Binns, Lynda Hawe and Marta Rilling for their support with the publication process. 


\section{TABLE OF CONTENTS}

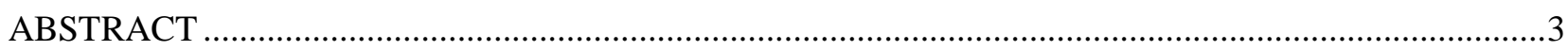

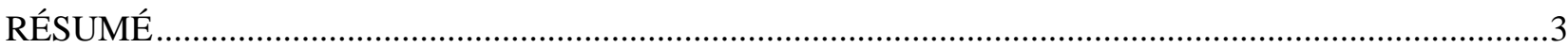

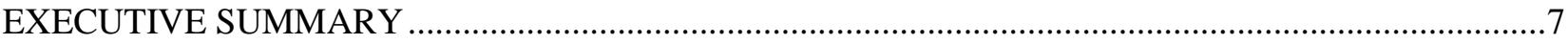

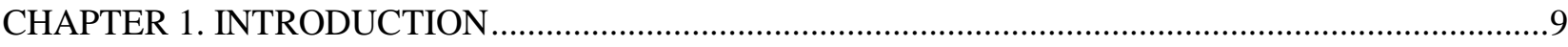

The importance of social and emotional skills for the lifetime success of children .................................9

Policy and learning contexts on social and emotional skills.....................................................................

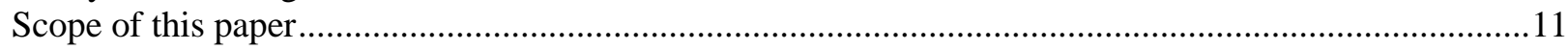

CHAPTER 2. CONCEPTUALISING SOCIAL AND EMOTIONAL SKILLS AND LEARNING

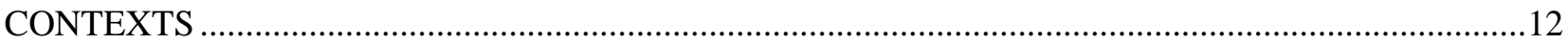

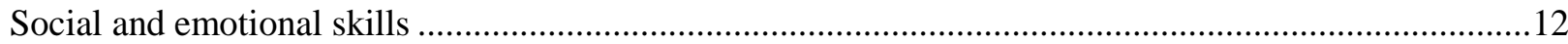

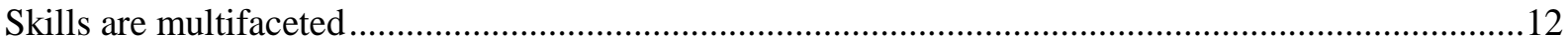

Skills need to be understood in a dynamic framework.........................................................................

Past skills are important determinants of current skills........................................................................14

Learning contexts that foster social and emotional skills ....................................................................15

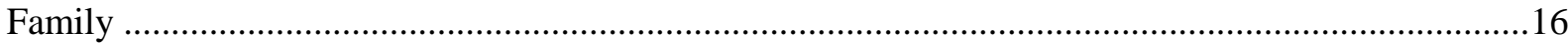

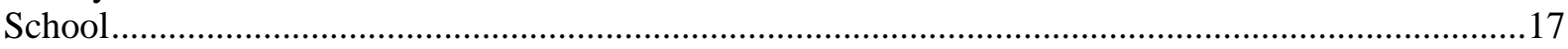

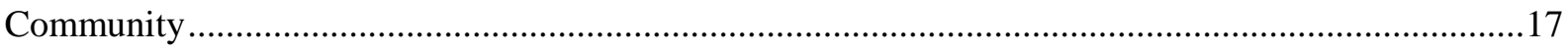

CHAPTER 3. WHICH LEARNING CONTEXTS MATTER? ................................................................

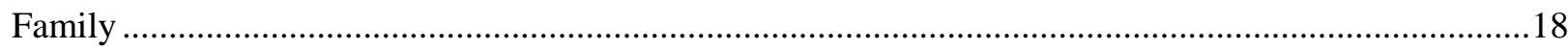

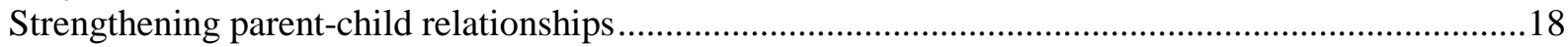

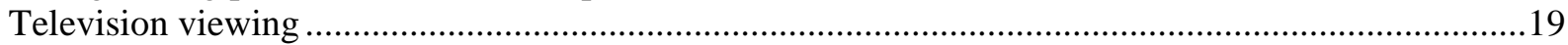

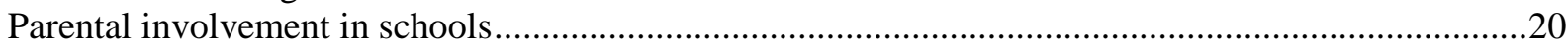

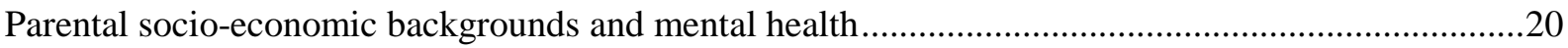

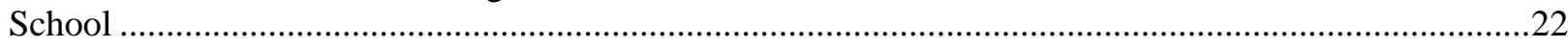

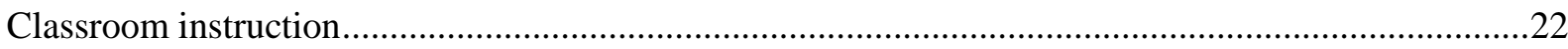

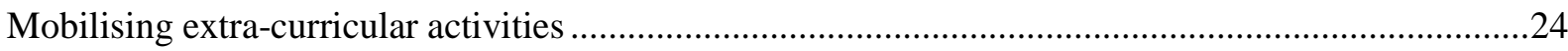

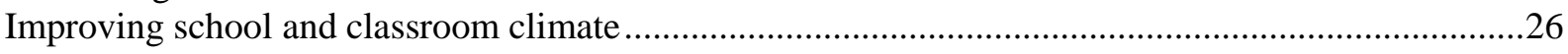

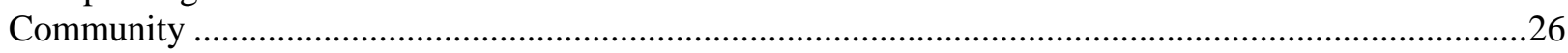

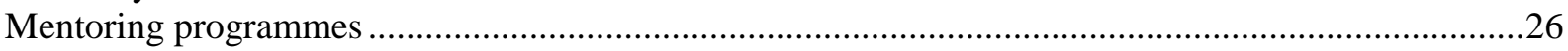

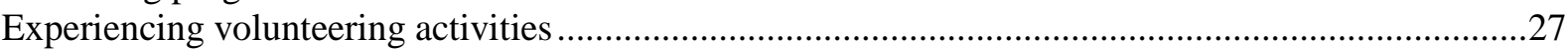

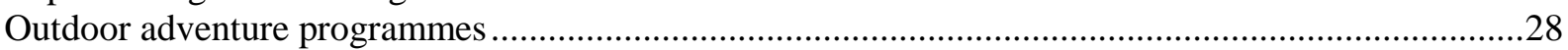

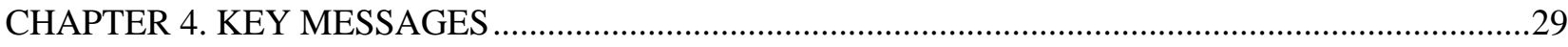

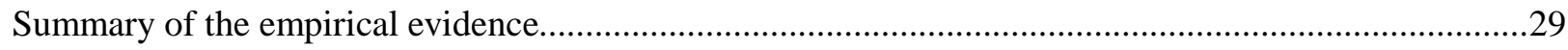

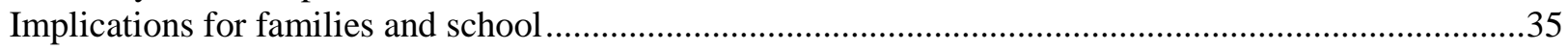

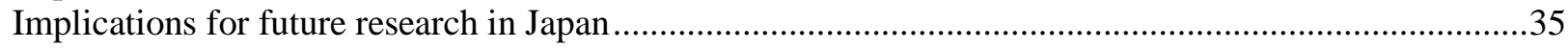

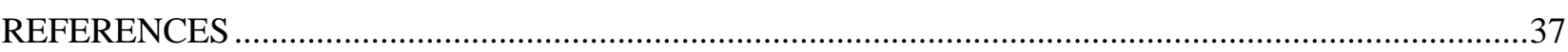

ANNEX 1. TYPES OF STUDIES INCLUDED IN THE PAPER ….........................................................

ANNEX 2. SOCIAL AND EMOTIONAL OUTCOMES OF SCHOOL-BASED INTERVENTION

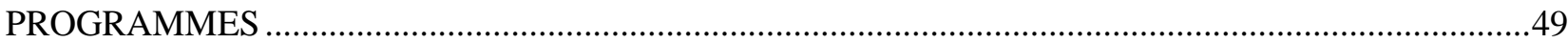




\section{Tables}

Table 2.1. Direct inputs, environmental factors and policy levers to enhance skills (examples) ..............16

Table 4.1A. Summary of results from international studies .....................................................................31

Table 4.1B. Summary of results from Japanese studies .............................................................................33

\section{Figures}

Figure 2.1. A framework for cognitive, social and emotional skills........................................................13

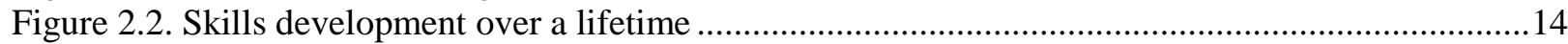

Figure 2.3. Dynamic interactions between cognitive and social and emotional skills.............................15

\section{Boxes}

Box 1.1. Policy discussions around social and emotional learning in Japan ..........................................10

Box 3.1. Maternal employment and children's social and emotional skills ...........................................22 
EDU/WKP(2015)10

\section{EXECUTIVE SUMMARY}

Education has great potential to address the challenges of the $21^{\text {st }}$ century by enhancing a variety of individual's skills. In particular, social and emotional skills can play an important role in driving social outcomes such as health, civic engagement and well-being. Children are not born with a fixed set of social and emotional skills, and some of these skills are malleable. Policy makers, teachers and parents can help facilitate children's skill development by improving the learning environments in which they develop. paper reviews international evidence, including those from Japan, with the aim of better understanding the learning contexts that can be conducive to children's social and emotional development.

Social and emotional skills can be defined as: "individual capacities that can be (a) manifested in consistent patterns of thoughts, feelings and behaviours, (b) developed through formal and informal learning experiences and (c) important drivers of socio-economic outcomes throughout the individual's life.” These skills include capacities to achieve goals (e.g. perseverance, motivation, self-regulation and self-efficacy), work with others (e.g. social skills, cooperativeness, trust and empathy) and manage emotions (e.g. self-esteem, self-confidence, low risk of internalising and externalising problem behaviours).

The paper has identified several learning contexts that may be conductive to enhancing social and emotional skills. First, home learning contexts can play an important role, as a number of studies point to the benefits of strong parent-child attachments. Some studies also suggest that parent's socio-economic situations and emotional conditions may affect their capacity to provide a socio-emotionally nurturing environment. Successful early childhood programmes and school-based programmes tend to offer parental training sessions to enhance parenting skills.

Second, schools can help improve students' social and emotional skills by mobilising curricular and extra-curricular activities. Curricular activities can strengthen children's social and emotional skills by introducing a set of lessons specifically designed to enhance social and emotional skills, as well as teaching strategies designed to enhance children's social and emotional skills through existing core academic curricular subjects. Schools may also usefully mobilise extra-curricular activities as well as practical experience in engaging in society (e.g. volunteering) and the labour market (e.g. apprenticeships). Moreover, they may help enhance students' social and emotional skills through improving school and classroom climate and effectively employing peer-support approaches.

Third, communities can offer various real-life settings which provide a motivating learning ground for children to acquire social and emotional skills. Some volunteering and outdoor programmes, when they are well designed, have been shown to effectively enhance children's social and emotional skills.

Lastly, a number of successful programmes designed to elevate social and emotional skills involve enhancement of multiple learning contexts including family, school and community. These programmes can provide not only opportunities for children to experience enhanced learning, but also for adults (e.g. parents, teachers and mentors) to receive appropriate training. Such a holistic approach to social and emotional development may help ensure that (a) programme objectives are shared across all stakeholders, (b) social and emotional learning approaches are coherent across contexts and (c) the knowledge and skills of all care providers are augmented. 
While most of the evidence comes from the United States and the United Kingdom, the international research community may usefully continue their efforts to expand studies based on a range of rigorous evaluation of intervention programmes and on large-scale longitudinal data that cover different population groups. This paper suggests that further efforts could be made by the research community in Japan in collecting and better exploiting micro-data on a range of social and emotional skills, as well as in evaluating effectiveness of interventions in raising social and emotional skills. 


\section{CHAPTER 1. INTRODUCTION}

Children are not born with a fixed set of social and emotional capabilities. Some of these skills are malleable, and policy makers, teachers and parents can play an important role in improving the learning environments in which they develop. The purpose of this paper is to better understand the learning contexts that can be conducive to children's social and emotional development. The analysis is based on international evidence including those from Japan. This will allow us to understand whether the emerging evidence from Japan is consistent with those coming from international sources, or is characterised by unique features. The evidence may also provide useful implications for education practices and research in Japan as well as in other countries.

\section{The importance of social and emotional skills for the lifetime success of children}

Today's socio-economic climate brings new challenges that affect the future of children. Although access to education has improved considerably, a good education alone no longer secures a job; youth have been particularly affected by rising unemployment following the economic crisis in 2008. Problems such as obesity and declining civic engagement are also increasing while the ageing population and the environmental outlook are cause for concern. Moreover, inequalities in labour markets and social outcomes appear to be widening.

Education has great potential to address these challenges by enhancing a variety of individual's skills. Cognitive skills matter, but social and emotional skills, such as perseverance, self-control and resilience are just as important. Research suggests that social and emotional skills can play a particularly important role in driving social outcomes such as health, civic engagement and well-being (see OECD, 2010, 2015 for a summary of the literature). Benefit-cost analyses of several prominent intervention programmes for social and emotional learning show that there is a substantial economic return to investment in these programmes through higher tax revenues and lower costs of public services for health, public assistance, and criminal justice (Belfield et al., 2015).

Contrary to popular misconceptions, children do not possess a fixed set of abilities with little room for improvement. They are not born as a "maths person", a "creative person" or an "attentive person". Children begin their lives with considerable potential to develop these abilities. Whether they flourish or not depends on the learning contexts that they are exposed to between early childhood and adolescence. Evidence suggests that this is due to the vast plasticity of the brain, i.e. its enormous capacity to learn, change and develop, during this period (Knudsen et al., 2006). Skills beget skills - early accumulation of skills becomes a foundation for future skill development.

Cognitive, social and emotional skills may develop independently: young children with high reading literacy are more likely to read books and further develop such skills, while those with high levels of curiosity early in life are more likely to invite stimulating experiences and may further enhance curiosity. But these skills can also influence each other as individuals progressively develop skills. For instance, children with strong self-control are more likely to follow through the work needed to finish reading a book, maths homework or a science project, all of which contribute to further enhancing cognitive skills.

\section{Policy and learning contexts on social and emotional skills}

Policy makers, teachers, employers and parents in OECD countries and partner economies generally recognise the need to equip individuals with social and emotional skills. In general, parents are likely to be concerned whether their children have sufficient levels of compassion, perseverance, self-esteem and 
creativity. Enterprises also look for social and emotional skills such as communication skills, leadership and creativity in their employees and often provide training programmes to enhance those skills.

This point is addressed in their national or sub-national policy statements, which highlight the importance of increasing children's autonomy, responsibility and the ability to co-operate with others. Such an emphasis is also reflected in national or sub-national curricula where social and emotional skills are addressed within and across subjects (see Box 1.1. for policy discussion related to social and emotional learning in Japan). Moreover, schools in most of these countries mobilise a range of extracurricular activities to enhance social and emotional skills. In many OECD countries and partner economies, general guidelines are available for schools to assess students' social and emotional skills. Schools tend to measure and report these skills in end-of-term school report cards (OECD, 2015).

\section{Box 1.1. Policy discussions around social and emotional learning in Japan}

Japanese Basic Act on Education of 1947 (revised in 2006) clearly sets out the objectives of education as the development of well-rounded character and citizenship with transversal skills. In Article 1, it defines the "Aims of Education" as follows:

Education shall aim for the full development of personality and strive to nurture the citizens, sound in mind and body, who are imbued with the qualities necessary for those who form a peaceful and democratic state and society.

Furthermore, Article 2 specifies the "Objectives of Education" to achieve these aims (relevant parts are underlined by the authors):

To realise the aforementioned aims, education shall be carried out in such a way as to achieve the following objectives, while respecting academic freedom:

1. To foster an attitude to acquire wide-ranging knowledge and culture, and to seek the truth, cultivate a rich sensibility and sense of morality, while developing a healthy body.

2. To develop the abilities of individuals while respecting their value; cultivate their creativity; foster a spirit of autonomy and independence; and foster an attitude to value labor while emphasising the connections with career and practical life.

3. To foster an attitude to value justice, responsibility, equality between men and women, mutual respect and cooperation, and actively contribute, in the public spirit, to the building and development of society.

4. To foster an attitude to respect life, care for nature, and contribute to the protection of the environment.

5. To foster an attitude to respect our traditions and culture, love the country and region that nurtured them, together with respect for other countries and a desire to contribute to world peace and the development of the international community.

Since the mid-1990s, the Ministry of Education, Culture, Sports, Science and Technology (MEXT) has been promoting education reform under the philosophy of "Zest for Living (ikiru chikara)" which is a notion that combines "a healthy body," "a well-rounded character" and "solid academic prowess" (MEXT, 2005). As a result, a new curricular activity called "Periods for integrated study" was introduced in the curriculum in elementary to upper secondary schools to enable students to self-reflect on their own lives through a variety of classroom learning methods such as crosssynthetic studies and inquiry studies.

Today MEXT is working towards the next revision of the curriculum guidelines in 2016-17. In this context, they established the "Review Committee on the Education Objectives, Contents and Evaluation Based on Qualities and Competences to be Fostered" to develop new frameworks of skills and discuss future educational objectives, curriculum guidelines and student evaluation. The Committee's discussions include questions on how the new skill framework could incorporate social and emotional skills needed in the future, such as autonomy, interpersonal skills, capacity to work with others, capacity to solve problems and create new values, and skills towards learning (e.g. motivation, concentration and endurance). 
Nevertheless, not many of these educational systems provide detailed guidance on how to enhance social and emotional development (OECD, 2015). For example, a country's national school curriculum does not necessarily provide explicit and practical instructions on how social and emotional skills might be taught in schools. While this provides schools and teachers flexibility when designing their own lessons, this may not help teachers who are unsure how to teach these skills most effectively. This may be particularly challenging among teachers who feel overwhelmed by the need to prepare students to perform well on core academic curricular subjects such as mathematics and languages. Some parents are also "left in the dark" while struggling to enhance their child's will power, self-esteem and altruism before they enter adulthood.

Although legislation and curricula are not the only available instruments that shape learning environments to foster social and emotional skills, educational systems may consider enhancing existing guidelines that build on successful practices and evidence in the literature. Some initiatives available in selected communities, school districts and individual schools offer good examples of ways to systematically collect useful information on social and emotional skills to identify those students in need of better pedagogy and guidance. There are already a number of promising pedagogical approaches and learning contexts that can be explored, as described in this paper. Systematic exchange of such information among educational stakeholders and researchers may help provide opportunities for others to experiment with such practices and enrich the evidence base. There is no one-size-fits-all solution, as there are considerable socio-cultural variations within, as well as across, countries that affect the nature of optimal learning contexts for children's social and emotional development. However, now is a good time to conduct a broad review of diverse learning contexts in order to identify if there are common features of learning contexts and intervention programmes that are conducive to social and emotional development.

\section{Scope of this paper}

This paper provides an overview of evidence on learning contexts that are likely to be conducive to social and emotional development. It mainly focuses on periods between birth and adolescence. The main sources of evidence are those studies that are relatively more amenable to causal inferences. Therefore, to the extent possible, this paper relies on evidence based on intervention studies with an experimental design (see Annex 1 for a description of study designs). As there is a paucity of such evidence, quasi-experiments (e.g. using comparison group identified ex-post) as well as longitudinal studies that exploit differences in the timing of learning contexts and skill outcome measures are also used. This paper largely relies on evidence presented in literature reviews conducted by Gutman and Schoon (2013), Kautz et al. (2014), OECD (2015), Noelke (forthcoming) and Collaborative for Academic, Social, and Emotional Learning (2012), as well as on the assessment of promising programmes described on the website of the Promising Practices Network (2014).

For Japanese studies, cross-sectional evidence is also included in the review due to a paucity of evidence that is based on experimental, quasi-experimental and longitudinal studies. Hence, the readers are invited to interpret the Japanese evidence presented in this paper with caution. The Japanese studies included in the paper are primarily those that were published during the past 15 years and are accessible online, and most of them have been identified through CiNii, an online database for academic publications in Japan. It is not an exhaustive review of the literature. 


\section{CHAPTER 2. CONCEPTUALISING SOCIAL AND EMOTIONAL SKILLS AND LEARNING CONTEXTS}

This chapter presents a framework for understanding social and emotional skills and the learning contexts that help enhance social and emotional skills. The framework provides the basis for synthesising existing evidence in the next section.

\section{Social and emotional skills}

In this paper, skills are broadly defined as: "individual characteristics that drive at least one dimension of individual well-being and socio-economic progress (productivity), that can be measured meaningfully (measurability) and that are malleable through environmental changes and investments (malleability)". Individuals need a multiplicity of skills to achieve diverse life goals. Some existing measures of skills can provide useful information for improving teaching and parenting practices.

Our framework considers cognitive, social and emotional dimensions of skills (Figure 2.1). Note that these skills are not independent of each other but rather interact and cross-fertilise as they develop over time.

\section{Skills are multifaceted}

Social and emotional skills - also known as non-cognitive skills, soft skills or character skills - are the kinds of skills involved in achieving goals, working with others and managing emotions. As such, they manifest themselves in countless everyday life situations. Figure 2.1 presents a categorisation of skills based on some of their most important functions. Clearly, such skills play a role in all stages of life: for instance, while children are taught which behaviour is appropriate when playing with others, adults need to learn the rules of team play in professional settings. People pursue goals from an early age (e.g. when playing games, solving puzzles) and this becomes increasingly important in adulthood (e.g. when pursuing academic degrees and jobs, etc.). Learning appropriate ways of showing positive and negative emotions and managing stress and frustration is a lifelong pursuit, especially when dealing with life changes such as divorce, unemployment and long-term disabilities. These broad skill categories (i.e. pursuing goals, working with others and managing emotions) include a number of lower-level skill constructs, as described in Figure 2.1. 
Figure 2.1. A framework for cognitive, social and emotional skills

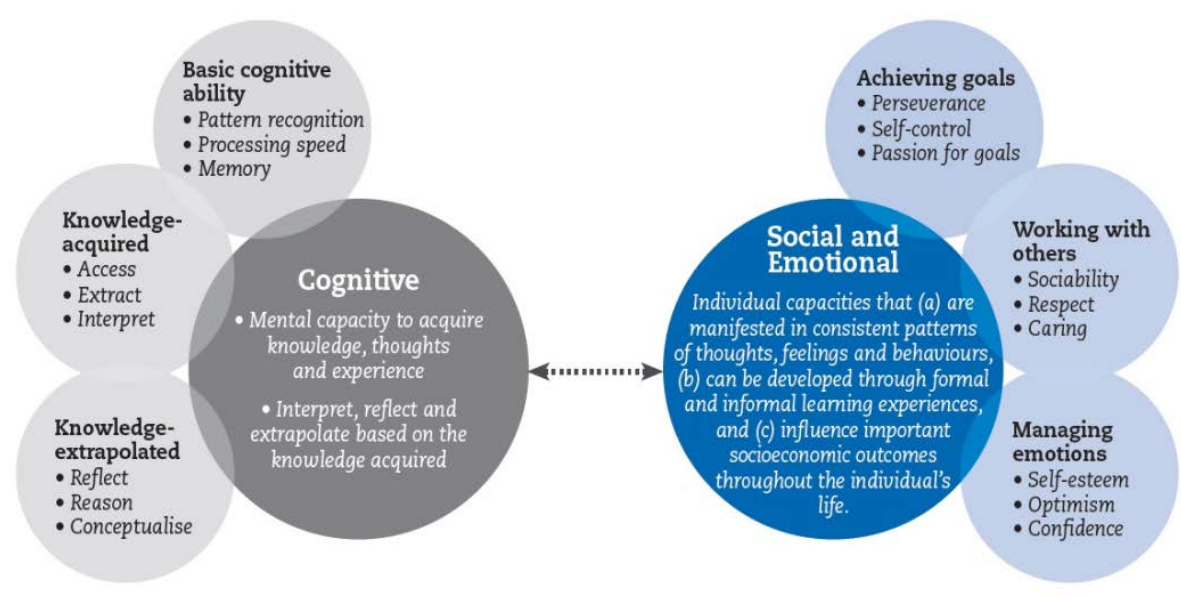

Source: OECD (2015)

Our framework defines social and emotional skills as: "individual capacities that can be (a) manifested in consistent patterns of thoughts, feelings and behaviours, (b) developed through formal and informal learning experiences and (c) important drivers of socio-economic outcomes throughout the individual's life." The definition emphasises the latent nature of the construct that is manifested in consistent patterns of individual's responses across situations and contexts. These skills can be enhanced, through environmental changes and investments and consequently drive individuals' future outcomes.

This framework is broadly in line with other existing frameworks that look at the individual characteristics that can be fostered through educational practices. Particularly, it draws upon the "Big Five" personality taxonomy that distinguishes five basic dimensions of personality traits: extraversion, agreeableness, conscientiousness, emotional stability (also known as neuroticism) and openness to experience. The framework is also broadly in line with other theoretical perspectives (e.g. temperament; social learning theory; positive psychology; grit) and existing frameworks (e.g. CASEL's Social and Emotional Learning Core Competencies).

While our framework distinguishes cognitive and socio-emotional skills, these two are not separable, as they interact and mutually influence each other. Skills such as creativity and critical thinking may be best understood by incorporating both cognitive and socio-emotional dimensions. Creativity, also referred to as divergent thinking, involves producing content that is not only novel, original and unexpected, but also appropriate, useful and adapted to the task at hand (Lubart, 1994). Creativity has been found to be related to measures of intelligence, as well as social and emotional skills. The Big Five framework also provides an understanding of some aspects of these complex skills. For instance, creative people tend to be more open to new experiences, imaginative, less conscientious, more impulsive and more extraverted (Feist, 1998). Critical thinking, on the other hand, involves the ability to use the rules of logic and costbenefit analysis, think strategically and apply the rules to new situations to solve problems. This skill has a very strong cognitive component relying on the ability to reflect on information, interpret it in a new context and find solutions to novel problems based on existing knowledge (Halpern, 1998). However, critical thinking also incorporates aspects of openness to new experience, such as imagination and unconventionality (John and Srivastava, 1999). Many real-life situations require the emergence of more complex skills that incorporate intellectual, social and emotional components. Therefore, the current framework should be seen as a synthesis of different aspects of skill domains that interact in everyday situations. 


\section{Skills need to be understood in a dynamic framework}

Skills progressively develop over time building on past learning, as Figure 2.2 illustrates. There is growing evidence that cognitive, social and emotional skills can be enhanced during an individual's lifetime. Skill development is not only affected by genes and the environment, but also by input from families, schools and the community. Parents assume a great responsibility in their children's skill formation as they shape many of the environmental factors that will influence children's development (through parents' choice of neighbourhood, educational programme and household characteristics). The impact culture, policies and institutions have on skill formation and across learning contexts should not be underestimated either. These diverse learning factors are crucial in understanding the process and are presented in detail in the following section.

Figure 2.2. Skills development over a lifetime

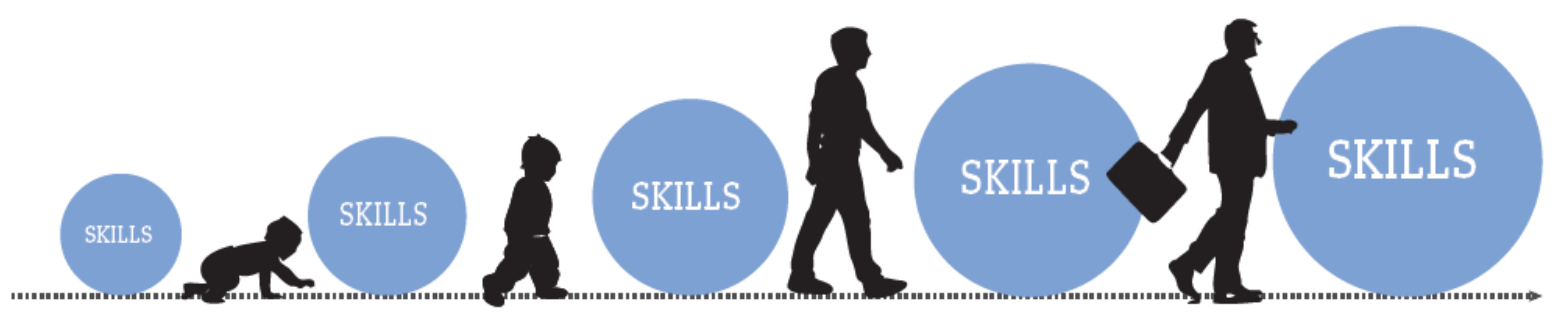

The rate of skill development largely depends on the individual's age and on their current level of skills. It is now recognised that there are sensitive periods for skill development. A child's early years matter tremendously in the development of skills, as they lay the foundations for future skill development. Investment in early childhood interventions brings the biggest returns in terms of securing higher levels of skills and positive adult outcomes (Kautz et al., 2014). During these years, family is of crucial importance and the patterns of interaction between parents and children have significant impacts on cognitive, social and emotional skills. However, later interventions can also be effective, especially in terms of social and emotional skills (OECD, 2015). During middle and late childhood and adolescence, schools, peer groups, and the community become increasingly important influences in shaping these skills. In addition, alternative programmes for those who drop out of school (i.e. in-work training) have also been found to be important for later skill development (Kautz et al., 2014).

\section{Past skills are important determinants of current skills}

"Skills beget skills" implies that, the higher the levels of skills that individuals have, the higher their gain in skills, as shown in Figure 2.3 (Carneiro and Heckman, 2003). This applies to the process of accumulating the same skill: for instance a child with relatively higher maths literacy than his or her peers at the point of entering school is more likely to end with even higher maths literacy at the end of the school year, compared to his or her peers. Moreover, there is also evidence of so-called cross-productivity whereby one type of skill can help foster other skills over time (Cunha and Heckman 2007; Cunha, Heckman and Schennach, 2010). This is particularly true for those individuals with higher levels of social and emotional skills, as these skills can aid cognitive skill development. For instance, a child who is very disciplined and persistent is more likely to increase his or her maths skills more than a child with equal levels of maths skills but with lower levels of discipline and persistence. Discipline and persistence may make it more likely that the child will focus on lessons and do homework regularly. Cognitive and social and emotional skills are thus tightly connected. More generally, those with higher skills are more likely to be able to elicit more from their learning contexts. A highly skilled child is more likely to select tools that 
advance his or her knowledge, or seek out further opportunities for growth (e.g. through extracurricular activities).

Figure 2.3. Dynamic interactions between cognitive and social and emotional skills

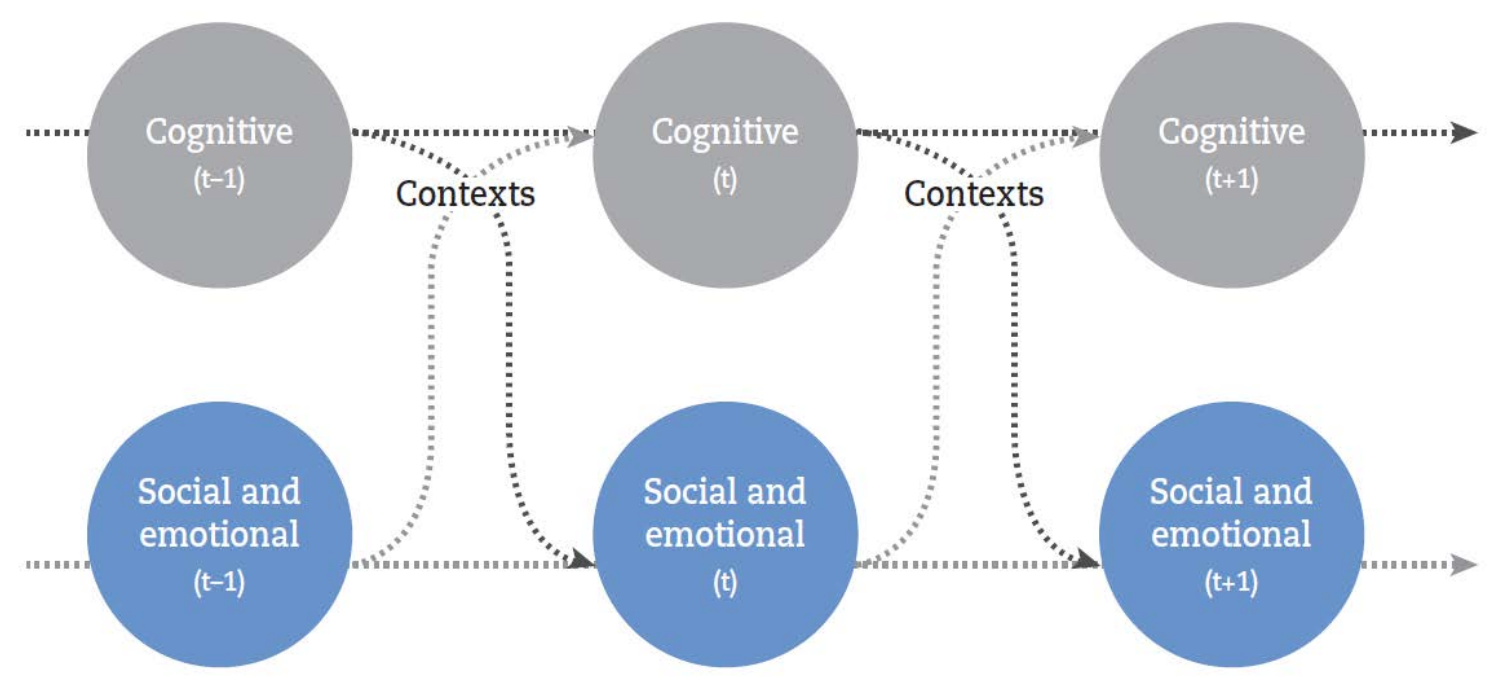

Source: OECD (2015)

Importantly, the sensitive periods for social and emotional skills are not quite the same as those for cognitive skills. While early investment is beneficial to all skills, social and emotional skills are more malleable at the later stages of life than cognitive skills (Cunha and Heckman, 2007; Cunha, Heckman and Schennach, 2010). Moreover, adolescence appears to be a period of particularly turbulent changes in social and emotional skills. For instance, adolescence tends to be associated with declines in discipline (conscientiousness), friendliness (agreeableness) and emotional stability (Soto et al., 2011). These negative changes seem to affect some children more than others and more research is needed to understand how some of the negative impacts could be buffered.

\section{Learning contexts that foster social and emotional skills}

This section describes a variety of ways in which children's social and emotional skills can be enhanced through families, schools and communities. Some of the successful programmes (as described in the next chapter) are designed in a way that these diverse contexts are well aligned so that children can reinforce the social and emotional skills they acquire within each learning contexts. This demonstrates the complementary nature of skills in that skills learnt in one environment can be reinforced in another and over time.

Children's social and emotional development takes place in a variety of settings including family, school and the community. Within each type of context we can distinguish a number of specific elements, with examples presented in Table 2.1. Each context contributes to the development of cognitive, social and emotional skills, though their relative importance will change depending on a child's stage in life. For instance, families are clearly crucial during infancy and early childhood, but schools and communities become increasingly important as a child enters formal education and starts interacting with diverse social networks. 
The impact of learning contexts on skills can be divided into direct inputs, environmental factors and policy levers. These represent different ways in which families, schools and communities shape skills. Direct inputs intentionally and explicitly affect skill development; for instance, parental involvement in child-rearing activities. Environmental factors, on the other hand, influence skill development indirectly by affecting the context in which skills can develop; for instance, the civic and cultural activities available to a child growing up in a particular community. Policy levers are elements of a learning context that can be directly or indirectly manipulated through policy inputs and can be used to foster skills; for instance, teacher training, which informs teachers' approaches to teaching cognitive, social and emotional skills.

Table 2.1 shows examples of the direct inputs, environmental factors and policy levers that can be found in different learning contexts. These learning contexts do not function in isolation from each other; rather they constantly interact and mutually influence each other. In fact, the patterns of interactions between contexts can themselves be related to skill development. For instance, parental involvement in children's schools, like attending parent-teacher meetings, may help children's skill development by improving both family and school learning contexts (El Nokali, Bachman and Votruba-Drzal, 2010). Indeed, many of the promising programmes for enhancing social and emotional skills (presented in the next section) have multiple treatments.

Table 2.1. Direct inputs, environmental factors and policy levers to enhance skills (examples)

\begin{tabular}{|l|l|l|l|}
\hline & \multicolumn{1}{|c|}{ Family } & \multicolumn{1}{c|}{ School } & \multicolumn{1}{c|}{ Community } \\
\hline Direct inputs & $\begin{array}{l}\text { Parental interaction with } \\
\text { children (e.g. reading books, } \\
\text { sharing meals and playing); } \\
\text { parenting styles; parental } \\
\text { modelling }\end{array}$ & $\begin{array}{l}\text { Curricular and extra-curricular } \\
\text { activities; teachers' pedagogic } \\
\text { skills and knowledge; teaching } \\
\text { styles; classroom climate; } \\
\text { apprenticeships and job training }\end{array}$ & $\begin{array}{l}\text { Activities offered in the } \\
\text { community (e.g. volunteering, } \\
\text { sport associations); mentoring; } \\
\text { media; social networks; peer } \\
\text { modelling }\end{array}$ \\
\hline $\begin{array}{l}\text { Environmental } \\
\text { factors }\end{array}$ & $\begin{array}{l}\text { Family's socio-economic } \\
\text { resources (e.g. income, } \\
\text { education); parental mental } \\
\text { health; family stress and } \\
\text { disturbing events (e.g. family } \\
\text { violence, maltreatment); } \\
\text { parental involvement in school }\end{array}$ & $\begin{array}{l}\text { School resources (e.g. } \\
\text { expenditure, facilities); school } \\
\text { climate and safety }\end{array}$ & $\begin{array}{l}\text { Public services (e.g. parks, } \\
\text { childcare, community centres); } \\
\text { neighbourhood safety; } \\
\text { unemployment rate; income } \\
\text { levels }\end{array}$ \\
\hline Policy levers & $\begin{array}{l}\text { Parental leave provisions; } \\
\text { flexible working arrangements; } \\
\text { childcare services; out-of- } \\
\text { school-hours childcare } \\
\text { services; family cash benefits }\end{array}$ & $\begin{array}{l}\text { Teacher recruitment and } \\
\text { training }\end{array}$ & $\begin{array}{l}\text { Training of social workers; } \\
\text { cultural and sport programmes }\end{array}$ \\
\hline
\end{tabular}

Learning in diverse social contexts points to the value of formal, informal and non-formal learning. Formal learning involves institutionalised, curriculum-based learning and teaching, for instance learning that occurs within the education system or workplace training (Werquin, 2010). Informal learning can take place within work, family or community contexts. It is unstructured and, from the learner's perspective, is unintentional (Cedefop, 2008). This type of learning happens, for instance, when children play. Nonformal learning is situated between formal and informal learning. It is structured and intentional, but not regulated, nor is it accredited or formally supported. An example might be teaching oneself how to use a particular piece of software.

\section{Family}

Families play an enormous role in shaping children's social and emotional development, particularly during early childhood. This can be due to the relatively longer time children spend in household contexts and the relatively higher brain plasticity during this period. Parent-child interactions (e.g. reading books, playing games and sharing meals) provide strong emotional ties between parents and children, which could help foster children's social skills as well as emotional stability. The nurturing effects of parents can be 
reinforced when parental attachments become part of family rituals or routines. Early caregiving characterised as sensitive, responsive, involved, proactive and providing structure has been associated with positive socio-emotional adjustment while those characterised as neglectful, harsh, distant, punitive, intrusive and reactive has been associated with various types of maladjustment (Shaw, 2014). Family socio-economic resources can also play an important role to the extent that higher income allows parents to prepare a better learning environment for the children. Hence, mother's employment may have positive or negative effects depending on the quality of the alternative learning contexts that children experience during early childhood. Policy levers can have indirect effects on children's social and emotional development depending on how much impact they have on improving parent-child relationships and socioeconomic resources.

\section{School}

Schools (including kindergartens) can also play an important role, given the evidence suggesting continued malleability of social and emotional skills during childhood and adolescence.

Schools have a variety of approaches to adopt in enhancing social and emotional skills. For instance, there are curricular activities specifically designed to enhance social and emotional skills. School can also adapt existing curricular activities to strengthen social and emotional skills while developing core academic skills (e.g. maths and languages). Moreover, schools can also work to improve school/classroom climate whereby students' social and emotional skills can be fostered.

Extra-curricular activities are another important means to enhance students' social and emotional skills. Club activities such as sport, music and arts are potentially powerful medium through which children can foster social and emotional development while learning other specific skills. Some schools offer students with opportunities to engage in community services (e.g. volunteering), a scheme typically called service-learning programmes. This provides students with an opportunity to engage in the labour market and reflect on this experience in classroom setting. This is considered a promising approach as it tends to trigger active engagement in real world, strengthen understanding of the community needs and provides a chance to reflect and deepen the understanding of the values of community engagement.

Upper secondary schools in a number of OECD countries have apprenticeships or job training programmes. These programmes, like service learning programmes, provide opportunities for students to engage in the world of work, whereby they experience tasks that have a concrete outputs that are useful for the community. Students can learn the value of collaborating with others and the importance of being perseverant and flexible, while gaining a sense of work satisfaction and self-esteem.

\section{Community}

Communities provide further opportunities for children to learn social and emotional skills through experiencing engagement in the real world. Communities generally offer diverse activities including outdoor programmes (e.g. boy scouts) and volunteering. There are also community-based mentoring programmes that match children with non-family mentors who would become "role models." 


\section{CHAPTER 3. WHICH LEARNING CONTEXTS MATTER?}

This chapter provides a synthesis of existing evidence on the learning contexts that can be conducive to nurturing children's social and emotional skills, based on international sources as well as from Japan. As described in Chapter 2, social and emotional skills include capacities to achieve goals (e.g. perseverance, motivation, self-regulation and self-efficacy), work with others (e.g. social skills, cooperativeness, trust and empathy) and manage emotions (e.g. self-esteem, self-confidence, absence of internalising and externalising problem behaviours). A range of international intervention programmes and large-scale longitudinal studies provide useful information to identify the learning contexts that may play an important role. While the paucity of rigorous programme evaluation and longitudinal datasets available in Japan limits similar inferences made, evidence based on cross-sectional studies still provide useful comparisons to the evidence available internationally.

\section{Family}

Imagine parents who regularly devote a considerable amount of time interacting with children by reading books, playing games and sharing meals. Do children benefit from such an experience beyond the momentary comfort of parental warmth? Do they experience social and emotional development that may have long lasting effects on their lives? This section focuses on parent-child relationship as a factor that directly influences children's social and emotional learning at home. It also covers television viewing, parental involvement in schools, parental socio-economic backgrounds and mental health.

\section{Strengthening parent-child relationships}

The international evidence suggests that parental attachment is an important component of practices designed to enhance children's social and emotional skills. A number of United States-based early childhood intervention programmes that have successfully enhanced children's social and emotional skills mobilise activities designed to strengthen parent-child relationship. For instance, in the Chicago Child Parent Center (CPC) programme, a large-scale preschool programme for disadvantaged communities, staff conducted regular home visits to teach parents various forms of play to encourage them to read with their children. The Syracuse Family Development Programme (FDRP), a large-scale programme targeted towards young, African-American, single-parent, low-income and low-education families, also assigns child development trainers who aim to increase family interaction, cohesiveness and nurturing through weekly family visits. The High/Scope Perry Pre-school Programme is a well-known early childhood intervention programme for disadvantaged families, in which trainers visit homes to help mothers improve parent-child relationships. These programmes are proven to have lasting effects on children's social and emotional development as demonstrated by increased academic motivation (CPC, High/Scope), reduced engagement in juvenile crime (CPC, FDRP) and improved adult economic stability and reduced adult criminal activity (High/Scope) (Kautz et al., 2014), although it is difficult to isolate the effects of improved parent-child relationships from the overall treatment effects.

Studies using large-scale longitudinal datasets provide evidence based on a much wider geographical scope and include population groups other than economically disadvantaged populations. A recent study using the Early Childhood Longitudinal Study's Birth Cohort (ECLS-B) data found that children who regularly sing, play, read books and eat dinner with their families tend to have higher ability to understand emotions as well as tendencies to express empathy, demonstrate self-regulation and form positive relationships with peers and adults (Muñiz et al., 2014).

The benefits of enhanced parent-child relationship can also be important after early childhood. The Seattle Social Development Project (SSDP), a programme targeted towards public elementary schools in 
high-crime areas of Seattle, suggests that school interventions focusing on interactions between children and their parents and teachers can enhance children's self-efficacy (Kautz et al, 2014). Moreover, the Pathways to Desistance (PDP), a multi-site longitudinal study of serious adolescent offenders, suggests that parenting styles characterised by high warmth and firmness relate with adolescents' sense of responsibility, empathy, anxiety and aggressive offences (Steinberg, Blatt-Eisengart and Cauffman, 2006).

Findings from Japanese longitudinal studies are consistent with the international evidence. Analyses of data from the Japan Children's Study (Annex 3), a birth cohort study conducted in Mie, Osaka and Tottori prefectures, suggest that maternal acts of praising and attitudes towards praising are associated with young children's social skills (Shinohara et al., 2010; Shinohara et al., 2011). This longitudinal study also suggests that mothers reading to children and fathers' involvement in child rearing are associated with children's responsiveness (Tanaka et al., 2010). Takeuchi et al. (2011) suggest that parenting styles termed "affectionless control" characterised by low responsiveness and overprotection are related to lower levels of persistence, self-directedness and cooperativeness and higher levels of harm avoidance and selftranscendence.

Cross-sectional studies have found that parenting styles during early childhood in which mothers emphasise communication and contacts with their children are related to children's higher levels of prosocial behaviours as well as lower risk of conduct problems and hyperactivity/inattention (Hamano and Uchida, 2012; Uchida and Ishida, 2011). Kanie et al. (2006) report that parental engagement in children's study and museum visits, as perceived by children, is positively correlated with children's self-esteem. In contrast, maternal lack of care and protection (i.e. neglectful parenting) and paternal overprotection have been shown to predict children's aggressive behaviours and delinquency (Hiramura, 2010). Togasaki and Sakano (1997) report that mother's negative parenting attitudes characterised by active refusal is related to children's lower social skills, particularly behaviours to develop and maintain relationships.

\section{Television viewing}

Media devices can be effective tools for parents to nurture children's social and emotional skills if they are used to complement social and emotional learning. However, media devices may also be used to substitute activities that involve parent-child interactions or interpersonal communication with peers. If the latter is the case, children who engage in long hours of media exposure are less likely to experience social and emotional development than otherwise. There may also be negative effects from media contents such as increased aggressiveness due to violent media contents. This paper focuses on television which is still the most popular media device.

Some of the international evidence suggests that young children's lengthy television viewing is negatively associated with their social and emotional development. An analysis using the British Millennium Cohort Study (MCS), a national birth cohort study with more than 10000 participants, found that watching television for three hours or longer a day at age 5 predicts a slight increase in conduct problems at age 7 (Parkes et al., 2013). Another study based on the United States' Children of the National Longitudinal Study of Youth (CNLSY), a spin-off cohort study of the 1979 National Longitudinal Study of Youth (NLSY79) that follows 1300 children over time, found that hours of television viewing at ages 1 and 3 were associated with attention problems at age 7 (Christakis et al., 2004).

The available evidence in Japan also suggests negative effects of excessive television viewing during early childhood on social and emotional development. Sugawara (2005) reports that one-year-olds who were exposed to television and video for longer hours tended to have lower scores in the communicative development test. She also found differences between those with higher scores and those with lower scores in other factors such as time spent playing outside, frequency of book reading by mother, maternal parenting attitude, maternal confidence toward her child, family cohesion assessed by parents. Cheng et al. 
(2010) report a positive association between young children's television viewing and behavioural problems, based on longitudinal data from the Japan Children's Study (Annex 3). They found that daily television exposure at 18 months old predicts the child's behavioural problems at age 30 months, particularly problems of hyperactivity-inattention and low pro-social behaviours. Similarly, Kano et al. (2007) found that children aged 36 months who watched television for 4 hours or more per day were more likely to experience slower social development (e.g. being able to share snacks or toys with friends or siblings, wanting to care for younger children, being able to wait their turn) than children with shorter television watching time.

As for school-age children, however, research results in Japan are mixed. For example, studies suggest both positive and negative relationships between children's television viewing time and their levels of aggression (Omi and Sakamoto, 2005; Shibuya et al., 2004).

One should interpret the above results with caution as it may well be children's social and emotional skills that are driving their excessive television viewing behaviours. For example, a study by Sugawara (2011) using the longitudinal data called Better Broadcasting for Children Project (Annex 3) found that television viewing hours were significantly longer for those six-year-olds who had exhibited high "harm avoidance" tendency at age zero, as characterised by excessive worrying, pessimism, shyness, and being fearful, doubtful and easily fatigued. This indicates a possibility that children's social and emotional skills affect their television viewing behaviours. To the extent that the evidence presented above do not control for this reverse causality, it is difficult to conclude the causal effects of television viewing.

\section{Parental involvement in schools}

Parents who are more engaged in school-based activities are more likely to be effective in parenting at home. This is not only due to the parenting techniques that parents may learn through these school-oriented programmes, but also the increased ability of parents to create a coherent and consistent learning environment for children between the school and home.

The international evidence suggests that parental involvement in school-based programmes designed to enhance social and emotional skills can be important. For example, the 4Rs programme has "Family Connection" activities that students take home to complete with their caregivers and parent workshops held at schools. The programme has been found to be effective in improving social competence and interpersonal negotiation strategies (Jones, Brown and Aber, 2011). In the Second Step programme, teachers send home a "Home Link" activity that gives students an opportunity to practice new skills with their caregivers. This programme is found to be effective in improving assertiveness, self-control, social competence, co-operative behaviour and perspective taking, as well as reducing internalising/externalising behaviour (Holsen, Smith and Frey, 2008; Schick and Cierpka, 2005; Grossman et al., 1997).

\section{Parental socio-economic backgrounds and mental health}

Family socio-economic backgrounds such as parental income, occupation, and education may also indirectly shape children's social and emotional skills, as they can affect parents' ability to provide responsive and consistent care and healthy emotional environment. There are a number of studies that show family socio-economic status has a positive impact on children's cognitive skills (see Noelke, forthcoming for a review), and recently some studies suggest that socio-economic status can also affect children's social and emotional skills. For example, analyses based on the National Longitudinal Study of Canadian Youth (NLSCY) suggest that child benefit expansions had positive effects on reducing children's aggression and anxiety as well as improving motor and social development (Milligan and Stabile, 2009, 2011). A study using the Early Childhood Longitudinal Study's Kindergarten Cohort (ECLS-K) panel data found that children differ substantially in social and emotional skills (approaches to 
learning, interpersonal skills, self-control, and externalising and internalising problem behaviours) by family income when they enter kindergarten, and these differences grow over time (Fletcher and Wolfe, 2012).

In Japan, there are also studies that report a positive correlation between family socio-economic status and children's social and emotional skills. For example, Shikishima, Yamashita and Akabayashi (2012) analysed data of 660 children in elementary and junior high school from the Japan Child Panel Survey 2011 (Annex 3), and found that family socio-economic background partially explains children's behavioural problems and pro-social behaviours. They found that children whose mothers have university degrees were more emotionally stable, had higher self-esteem and reported higher adjustment at school, compared with their peers whose mothers do not have university degrees. The authors also observed that children from higher income households were more likely to report better emotional stability, lower risk of behavioural problems and higher school adjustment.

Maternal mental health also appears to predict children's social and emotional skills. Studies in the United States suggest that maternal mental health is a key factor that influences child cognitive, social and emotional development. NICHD (1999) reports that children whose mothers reported feeling depressed were rated as less cooperative and more problematic at 36 months. Similarly, Frank and Meara (2009) analysed longitudinal data of the NLSY79 and found a strong relationship between maternal depression and behavioural problems among seven to 14-year-olds. Moreover, clinical research suggests that children of depressed mothers present lower psychiatric symptoms if their mothers' depressive symptoms improve (Wickramaratne et al., 2011).

A study using the Millennium Cohort Studies (MCS) report suggests that maternal depression was strongly associated with mothers' reports of children's behavioural problems (both internalising and externalising problems) (Kiernan and Huerta, 2008). Furthermore, this study found maternal depression was noticeably associated with the use of harsh disciplinary practices (more frequent striking and shouting), which in turn were very strongly related to conduct problems amongst the children. A substantial part of the effect of economic deprivation on child behaviour problems was mediated through the mother's depression, which is consistent with the perspective of family stress theory.

Findings from Japanese longitudinal studies are consistent with ones from international research and suggest a strong relationship between maternal mental health and children's social and emotional skills. Sugawara et al. (1999) report a significant relationship between maternal depression during the early postpartum period and infants' persistence and frustration tolerance (temperament scale) at the age of six months using the longitudinal dataset of the Kawasaki project (Annex 3). On the other hand, maternal depression when the child was 12 months old did not have such a relationship with the two temperament dimensions. These results indicate that maternal depression may have different relationships with infant temperament over time. An intervention study with a randomised control trial in Yamanashi prefecture by Cheng et al. (2007) suggests that early maternal depression significantly increased the risk of child behavioural problems. Shikishima, Yamashita and Akabayashi (2012), using the Japan Child Panel Survey (Annex 3) data of children aged 6-15, also report that children's problem behaviours hadthe strongest relationship with maternal mental health amongst several family background variables. However, the authors called for a caution in interpreting the relationships between maternal mental health and child behavioural outcomes. They may simply be a result of (1) children's problem behaviours affecting maternal mental health, (2) genes influencing both maternal mental health and child problem behaviours, and (3) maternal mental health affecting mother's responses to the questionnaires. 


\section{Box 3.1. Maternal employment and children's social and emotional skills}

Many OECD countries are exploring ways to expand female employment. Of particular interest is identifying how labour market and social policies can help bring women back to the labour market after childbirth. While there are numerous benefits of female labour market participation for the individuals and the society, the evidence on the impact of maternal labour market participation on children's social and emotional development is mixed. Noelke's (forthcoming) review of studies in North America and Europe indicates that maternal employment in general has neither a negative nor a positive effect on child development. However, among families with disadvantaged socioeconomic backgrounds, the impact of maternal employment on children's cognitive, social and emotional development tends to be positive. Among those socio-economically advantaged, maternal employment effects tend to be negative.

International evidence points to the heterogeneity of the effects of maternal employment across household socioeconomic situations. Lucas-Thompson et al. (2010) present a meta-analysis of 69 studies on the relationship between early maternal employment during a child's first three years of life and the child's academic achievement and behavioural problems. They found that while effect sizes were overall small or non-significant, early maternal employment was beneficial for children from single-parent families and families receiving welfare. In contrast, negative effects were observed among middle-class and two-parent families and for employment during the child's first year of life. Gregg et al. (2005) and Ruhm (2004) also found that full-time maternal employment in the first year after birth may have negative effects on development of children from socio-economically advantaged families - typically two-parent families with higher educated mothers. Similar conclusions are derived from Huerta et al. (2011) who analysed longitudinal data of five OECD countries. They suggest that a return to paid work by mothers within six months after childbirth was negatively associated with child outcomes, although the associations were small and not observed in all countries. Moreover, the negative associations were largely observed among children in intact families or in families where parents have high levels of education. This negative relationship was no longer observed when mothers returned to work after the child's first year of life. Children with advantaged backgrounds may have more to lose than their less advantaged peers when their mothers are working.

Some studies in Japan suggest that maternal employment may have positive effects on child's social and emotional skill development. Using longitudinal data from the "Kawasaki Project" (Annex 3), Sugawara et al. (2006) suggest that children whose mothers returned to work before the child reached three-years-old had slightly "fewer" externalising problems, compared with children whose mothers stayed at home. Kan (2012) analysed the effect of maternal employment during junior high school years on children's cognitive, social and emotional skills during junior high school years, using retrospective data, and found that maternal full-time employment prevented their sons from smoking cigarettes at school. Sugawara et al. (2006) provide the following potential explanations for the positive effects of maternal employment on children's social and emotional skills: (1) maternal employment may positively influence maternal mental health, which, in turn, helps reduce children's behavioural problems; and (2) children of working mothers may have more opportunities to interact with other children and adults by attending formal child care centres, which helps their social skill development.

\section{School}

Do children develop their social and emotional skills by experiencing systematic social and emotional learning at school? What are benefits of different school-based extra-curricular activities to children's social and emotional skills? Does an open, supportive and safe school climate help children's social and emotional learning? This section covers some approaches related to classroom instruction, extra-curricular activities, and school/classroom climate, among school-based activities for social and emotional learning.

\section{Classroom instruction}

There are a number of school-based (including early childhood) programmes specifically designed to increase social and emotional skills. These programmes typically provide specific lessons focusing explicitly on instruction of social and emotional skills and/or strategies to embed social and emotional learning in core curricular activities such as English and mathematics. 
EDU/WKP(2015)10

\section{Lessons designed to enhance social and emotional skills}

The international evidence, mostly United States-based, provides examples of successful curricular activities specifically designed to enhance social and emotional skills (Annex 2). While each programme has a different set of distinctive goals and targeted skills, they tend to be particularly effective in raising children's capacities to work with others and to manage emotions. These programmes typically employ a variety of hands-on activities so that students internalise learning and apply it to everyday life.

For instance, the above-mentioned Second Step programme contains sets of age-appropriate lessons for pre-kindergarten through eighth grade to be taught once a week. There are three to five units for each grade, such as skills for learning, empathy, emotion management, problem solving, bullying prevention and substance abuse prevention, with each unit consisting of several weekly lessons. In a sample lesson on "disagreeing respectfully," students would watch video and engage in partner activities, group discussion and skill practice through role-play. The "I Can Problem Solve" (ICPS) programme, another American school-based prevention programme for pre-kindergarten to elementary school children, offers a series of 15- to 45-minute structured lessons that can be conducted daily or every other day (59 lessons for preschool; 83 lessons for kindergarten through Grade 2; and 77 lessons for Grade 3 through Grade 6). Earlier lessons focus on "pre-problem-solving skills" that involves learning vocabulary to understand one's own and other people's feelings. Later lessons aim to develop interpersonal problem-solving skills through games, stories, puppets, illustrations, and role-plays. Teachers do not tell students solutions, but instead help them to think of their own ideas. Both randomised control trials as well as a quasi-experimental study suggest that the programme has improved children's self-regulation and patience.

In Japan, several social and emotional learning programmes are available for school practitioners, and most of them have lesson plans specifically designed to enhance social and emotional skills. Teachers often use these programmes during curricular activities called the "period for integrated studies" (Box 1.1), while these programmes tend to be relatively short. Several evaluation studies in Japan report positive programme effects on social and emotional skills, although these evaluations do not have control groups. For example, Ando (2008) reports that the programme named the "Successful Self" programme, a schoolbased prevention programme, was effective in reducing elementary school students' impulsivity/aggression and school maladjustment including physical and verbal bullying and emotional problems. The programme consists of four lessons involving individual reflection and group discussion on positive self-image, interpersonal problem solving strategies and stress management. Ando (2010) also reports that a similar programme targeted towards junior high school students ("Successful Self 2") improved students' diligence, friendliness, mood (e.g. depression and anxiety) and social skills. Fujieda and Aikawa (2001) developed a classroom-wide social skills training programme for elementary school students, and report that students' interpersonal skills improved after the training. The training contained 10 lessons, each of which involved teacher's instruction and demonstration of target skills, students' role plays and selfreflection, and teacher's feedback. Watanabe and Harada (2007) also developed a social skill training programme for high school students involving teachers' instruction and demonstration, students' role-plays, and teacher's feedback, and report that students' self-esteem and ability to sympathise with and support others improved after the training. Harada (2014) evaluated a similar social skill training programme for high school students with larger groups of students, and found that students' assertiveness and emotional control improved after the training.

\section{Embedding social and emotional learning in core curricular activities}

The international evidence, mostly United States-based, also provides examples of successful programmes that embed social and emotional learning in core curricular activities. One of them is the RULER Approach, a school-wide programme designed to promote emotional literacy in kindergarten through eighth grade. This programme provides systematic professional development for the adults 
involved in the education of children (school leaders, teachers, support staff and families). It enables teachers to integrate emotional learning into a wide range of subject areas such as English (language arts). In the "Feeling Words Curriculum," students learn emotion-related vocabulary words and connect them to academic materials or current events. This approach, based on a randomised control trial, has been found to be effective in improving adaptability skills (social skills, leadership and study skills) (Brackett et al., 2012). The Responsive Classroom approach, a classroom-based programme for kindergarten through sixth grade, incorporates essential teaching practices and practical strategies including morning meetings, rule creation, interactive modelling, and positive teacher language. This programme, based on a quasiexperimental study, has been found to be effective in increasing assertiveness, co-operation and prosociality with peers and reducing anxiety, fear and aggressiveness with peers (Brock et al., 2008; RimmKaufman and Chiu, 2007).

In Japan, there are studies suggesting that programmes promoting collaborative learning during English and Japanese lessons may increase students' pro-social skills and interpersonal skills (Ikejima and Fukui, 2012; Ikejima et al., 2004).

\section{Peer support approaches}

International evidence from effective intervention programmes suggests that peer support approaches can be effective in increasing social and emotional skills. For example, the Caring School Community programme provides Cross-Age Buddies activities in which pairs of older and younger students promote bonding through academic and recreational activities. Several randomised control trials and quasiexperimental studies show that programme participation improved children's social behaviours, and reduced conduct problems and emotional distress (e.g. Solomon et al., 2000).

Another potential peer support approach is peer mediation, in which students learn how to resolve conflicts by experiencing being mediators under the supervision of adult trainers. Based on two large-scale randomised-control trials, a United States-based programme with strong peer-mediation component called Resolving Conflict Creatively Program (RCCP), shows positive effects on improving negotiation strategies and reducing conduct problems (Aber, Brown and Jones, 2003; Aber et al., 1998).

In Japan, Taki (2004, 2009) has developed the "Japanese Peer Support Program” that aims at developing students' self-efficacy through multi-grade activities, where older students take care of younger students. The programme is expected to provide young students with role models while increasing older students' sense of self-worth. Such multi-grade interaction activities have been found to be effective in enhancing students' sociality (National Institute for Educational Policy, 2008). Peer mediation has been recently introduced to education practitioners as a potentially effective tool to solve issues of school bullying and develop students' pro-sociality, but evaluation studies are still limited and their results are mixed. Aoki et al. (2013) report that a peer mediation training programme increased elementary school students' self-efficacy, particularly for those whose initial self-efficacy levels were lower. However, Ikejima et al. (2005) report that similar peer mediation training had no significant impact on elementary school students' interpersonal skills.

\section{Mobilising extra-curricular activities}

Extra-curricular activities are expected to provide effective learning opportunities for enhancing children's social and emotional skills. In Japan, the curriculum standards specify minimum hours that schools should secure for special activities such as homeroom activities, student government, club activities and school events. Moreover, international evidence suggests that service learning programmes and apprenticeship programmes that offer experience outside school are also effective in strengthening social and emotional skills. 


\section{Clubs and other after-school programmes}

International research generally suggests that extra-curricular activities help enhance social and emotional skills. A meta-analysis of after-school programmes that seek to enhance the personal and social skills of children and adolescents indicates that, compared to the control group, participants demonstrate significant increases in their self-perceptions (e.g. self-esteem, self-concept and self-efficacy) and bonding to school, positive social behaviours and academic achievement, and significant reductions in problem behaviours (Durlak, Weissberg \& Pachan, 2010). The analysis indicates that programmes that are "sequenced, active, focused, and explicit (SAFE)" are particularly effective. Another meta-analysis of extracurricular activities both in and out of school suggests that participation in performing arts and prosocial activities had a strong relationship with identity and self-esteem (Lewis, 2004).

A United States-based study by Covay and Carbonaro (2010) suggests that elementary school children who participate in music lessons, dance lessons, performing arts activities, art lessons, sports and clubs outside of school hours demonstrate greater attentiveness, organisation, flexibility, task persistence, learning independence and eagerness to learn, as compared to their peers who do not participate in such activities. A study based on the German Socio-Economic Panel, a large-scale longitudinal study in Germany, suggests that adolescents who receive music training tend to be more conscientious, open and ambitious (Hille and Schupp, 2015). There are also studies suggesting that performing arts activities such as theatre and dance activities can enhance social and emotional skills, such as self-esteem, self-control, perseverance, social skills, emotion regulation and sympathy (for a review of the studies see Winner, Goldstein and Vincent-Lancrin, 2013).

In Japan, cross-sectional research suggests that participation in club activities is related to higher social and emotional skill levels. For example, Yamamoto, Araki and Kamino (2010) found that high school students participating in club activities had higher level of social and emotional skills related to achieving goals, expressing opinions and working with others. Aoki (2005) also found a positive relationship between high school students' athletic club participation and their levels of social skills.

\section{Service learning programmes}

In the United States, service-learning is an activity that combines meaningful service in the community with formal educational curriculum and structured time for participants to reflect on their service experience. Melchior et al. (1999) evaluated service learning programmes called Learn and Serve programmes at 17 middle and high schools in the United States, and found that students who participated in service learning improved acceptance of cultural diversity, service leadership, civic attitudes and volunteer behaviour and reduced engagement in risky behaviour (i.e. arrested during the past six months, ever pregnant/made pregnant). A meta-analysis by Celio, Durlak and Dymnicki (2011) of 62 international studies indicates that, compared to controls, students participating in service learning programmes demonstrate significant gains in five outcome areas: attitudes toward self, attitudes toward school and learning, civic engagement, social skills and academic performance. Another meta-analysis by Conway, Amel and Gerwein (2009) suggests that service learning had small but positive effects on personal, social and civic outcomes, such as self-evaluations, skill in interacting with others and personally responsible citizenship.

\section{Apprenticeships and job training}

Kautz et al. (2014) point out that integrating career development into a standard high school can have long-term labour market benefits. For example, Career Academies in the Unites States that expose students to career-oriented activities have positive and sustained impacts on male participants' earnings and employment, possibly through improving non-cognitive skills. Apprenticeship programmes in Europe 
that carry out work-based and classroom learning are also found to have effects on wages and wage growth. An analysis of the Transitions from Education to Employment (TREE) - a Swiss longitudinal study suggests that young people who participated in work-based education were more agreeable and emotionally stable compared to their peers who participated in vocational schooling (Bolli and Hof, 2014). The authors have not identified any related evidence in Japan.

\section{Improving school and classroom climate}

The international evidence provides many examples of successful programmes that promote positive school and/or classroom climate, among other approaches, to facilitate social and emotional learning. For instance, the Open Circle Programme (OCP), a programme with 34 structured lessons that cover relationship building and communication skills, understanding and managing emotions, and problem solving, generates school and classroom climates that provide safe settings for children to discuss important issues. The programme introduces a highly interactive climate, incorporating large and small group discussions, role-playing and community-building activities. The above mentioned RULER Approach is designed to improve the classroom's atmosphere by enhancing positive emotional support (e.g. creating warmth and respect in classroom interactions), reducing negative climates (e.g. reducing hostility in classroom interactions), improving teacher sensitivity (e.g. the extent to which teachers respond to students' emotional and academic needs) and raising teachers' regard for student perspective (e.g. the extent to which classroom activities incorporate students' points of view).

In Japan, some studies have found a relationship between the classroom's climate and students' social and emotional skills, although students in the classroom measure the classroom's climate themselves. Udagawa and Shimoda (2013) found a positive correlation between elementary school students' assertiveness and their satisfaction with their classroom environment. Takahashi, Kawashima and Yoshikawa (2010) found that elementary school students who report higher levels of classroom satisfaction tend to have higher levels of social skills and may influence the social skill levels of other students in their classroom. Komatsu and Hida (2008) report that elementary school students who perceive positive classroom climate tend to have higher self-rating of social skills.

\section{Community}

Communities provide children with informal and non-formal learning opportunities. In particular, some programmes provided by communities can be factors that directly influence children's social and emotional skills. This section covers mentoring programmes, volunteering activities and outdoor adventure programmes among such programmes.

\section{Mentoring programmes}

Mentoring can be an effective way to enhance youth's social and emotional skills. A meta-analysis of mentoring programmes among children and adolescents by DuBois et al. (2011) concludes that mentoring programmes can improve behavioural, social and emotional, and academic outcomes of youth. The authors observe that mentoring can serve both promotion and prevention aims.

In the United States, a number of community-based mentoring programmes for at-risk youth are in place. At the Big Brothers Big Sisters of America (BBBSA), a well-known mentoring programme for vulnerable children aged 10-16, adult volunteers regularly meet with children and share activities over one year. Evaluation of the BBBSA suggests that the programme reduces a variety of antisocial behaviours, such as hitting, stealing, damaging property and skipping class or day of school (Tierney, Grossman and Resch, 2000). 
Following the success of community-based mentoring programmes, many school-based mentoring programmes have been introduced in the United States. In a typical school-based mentoring programme, volunteer mentors and students from the participating school are matched on a one-to-one basis, and spend their time together participating in a range of activities at school throughout the academic year (Wheeler, Keller and DuBois, 2010). Wheeler, Keller and DuBois (2010) reviewed three randomised control trials of school-based mentoring programmes, and concluded that school-based mentoring programmes have small but significant effects on school-related misconduct, absenteeism and truancy. Furthermore, the analysis of effects of the school-based BBBSA programme by Herrera et al. (2007) suggests that effects were more favourable when adults rather than high school students were mentors, when mentors reported receiving adequate levels of support, and when schools provide adequate access to school resources and space.

In Japan, while mentoring programmes have not been widely recognised yet, limited research in this field suggests positive effects. For example, Hiroshima city has been running a mentoring programme for elementary and junior high school students since 2004, and the questionnaires with its participants, mentors and participants' parents suggested improvement in the participants' emotional maturity, study habits, self-control behaviour and relationship with others (Watanabe et al., 2012). Mentors are volunteering adults trained by the city, and any student can participate in the programme free of charge. The programme typically lasts one year, during which mentors and mentees meet for two hours each week at their houses or in other places such as community centres. While mentoring sessions take place outside school, the programme is run in partnership with schools. For example, schools recommend the programme to parents, and first meetings between mentors and students are often arranged at school with presence of teachers (Watanabe, 2008). Another intervention programme in Japan that incorporates mentoring is the "Mental Friend" programme, in which young adult volunteers support children who do not attend school. The programme has been implemented by local governments with support from the Ministry of Health, Labour and Welfare. Although empirical evaluation has not been conducted, some qualitative studies suggest positive effects of the programme. For example, a survey on administrative staff in charge of the Mental Friend programmes suggests that children who participated in the programme became more extraverted, motivated and active in relating with others, with decreased behavioural problems (Kurita, 2014). Moreover, the organisation Big Brothers and Sisters Movement of Japan runs a mentoring programme for juveniles under probation, while no evaluation study has been identified.

\section{Experiencing volunteering activities}

International research suggests positive impact of community volunteering activities on youth's social and emotional skills, while the effect appears smaller than service learning (Gutman and Schoon, 2013). Some studies suggest that those who experienced volunteering activities during childhood are more likely to demonstrate higher pro-sociality in adulthood. The Canada Survey of Giving, Volunteering and Participating (CSGVP) suggest that those who reported being active in religious organisations, belonging to a youth group, or volunteering as youth were more likely than others to report making charitable donations and volunteering as adults (Hall et al., 2009). Similarly, a study on American adults suggests that those who began volunteering as youth are twice as likely to volunteer as those who did not volunteer when they were younger (Toppe, Kirsch and Michel, 2001).

In Japan, a few studies on adults suggest that volunteering experience may increase social skills (Midzuno and Kato, 2007; Baba, Shima and Oya, 2006). 


\section{Outdoor adventure programmes}

International research generally finds that adventure programmes are beneficial for developing social and emotional skills. Meta-analyses suggest effects of adventure programmes on locus of control ${ }^{1}$ (Hans et al., 2000), reduction in delinquency (Wilson and Lipsey, 2000), self-efficacy, behavioural observations, personality measures and self-esteem or self-concept (Gillis and Speelman, 2008). Wilson and Lipsey (2000) report that programmes involving relatively intense activities or with therapeutic enhancements were particularly effective in reducing delinquent behaviour.

In Japan, several studies also suggest potential positive impacts of outdoor adventure programmes on social and emotional skills. For example, Kataoka et al. (2011) suggest that participation in the Girl Scouts may increase high school and junior high school girls' self-esteem. The National Institution for Youth and Education (NIYE) (2010) reports a potential link between community and outdoor activities during childhood and social and emotional skills in adolescence and adulthood. The Institution analysed responses from 11000 high school students and 5000 adults on their childhood experiences and found that those who reported experience with nature, playing with peers and participation in community activities in childhood tended to be more open to new experiences, have higher normative consciousness and have higher interpersonal skills.

Moreover, potential effects of short-term outdoor activities on children's social and emotional skills have also been suggested. For example, Yasunami et al. (2006) report that elementary school students who participated in the six-day nature school programme generally increased their skills such as ability to make own judgment, leadership and interpersonal skills. They also report that some optional activities such as outdoor cooking appear particularly effective, while some other activities such as recreational activities appear less effective. Nakagawa et al. (2005) report that early adolescents who participated in a 15-day camping programme increased their ability to make own judgment and their interest in nature, while participants in a three-day camping programme increased extraversion and cooperation. Ihara et al. (2004) report that early adolescents who participated in an adventure programme increased their general selfefficacy.

1 Locus of control is defined by Rotter (1990) as "the degree to which persons expect that a reinforcement or an outcome of their behavior is contingent on their own behavior or personal characteristics”. 


\section{CHAPTER 4. KEY MESSAGES}

This chapter concludes the paper by outlining the summary of key findings with implications for families, schools and the research community in Japan.

\section{Summary of the empirical evidence}

This paper has identified several characteristics of learning contexts that may be conductive to enhancing children's capacities to achieve goals (e.g. perseverance, motivation, self-regulation and selfefficacy), work with others (e.g. social skills, cooperativeness, trust and empathy) and manage emotions (e.g. self-esteem, self-confidence, low risk of internalising and externalising problem behaviours). Tables 4.1A and 4.1B present a summary of the empirical evidence discussed in this paper.

Families can foster children's social and emotional development through warmand regular parent-child interactions.

A number of studies point to the benefits of intensive parent-child attachments on children's social and emotional development. Some of the successful programmes involve regular family activities such as reading books, sharing meals, playing together, and accompanying museum visits. These practices can provide children with a sense of a warm and secure environment as well as with opportunities to closely interact and communicate with adults. Some studies also suggest that parent's socio-economic situations and emotional conditions may affect their capacity to provide a socio-emotionally nurturing environment. Successful early childhood programmes tend to offer parental training sessions to enhance parenting skills. Many successful school-based programmes also involve parents and provide them with opportunities to learn to create a coherent learning context between school and home. Findings from research in Japan are consistent with those from the international evidence.

Schools can employ a range of curricular and extra-curricular activities to stimulate children and adolescent's social and emotional development.

Quality school-based social and emotional learning programmes can help children acquire the capacity to achieve goals, work with others and manage emotions. These programmes tend to mobilise either (a) a set of lessons specifically designed to enhance social and emotional skills including those that employ scenarios and role-playing, or (b) teaching strategies designed to enhance children's social and emotional skills through existing core academic curricular subjects, such as introducing collaborative problem solving. The latter approach may be particularly relevant for Japanese schools where securing time and resources for developing and implementing social and emotional learning curriculum can be difficult. Successful social and emotional learning programmes tend to be highly interactive, proactive, reflective, practical, intentional and experiential.

Schools may also usefully mobilise extra-curricular activities as well as practical experience in engaging in society (e.g. volunteering) and the labour market (e.g. apprenticeships). Moreover, they may help enhance students' social and emotional skills through improving school and classroom climate and effectively employing peer-support approaches.

Community may complement efforts made by families and schools by providing opportunities for children to learn social and emotional skills through practical experiences.

One of the important goals of education is to develop children's capacity, attitudes and values in order to help them become responsible and active citizens. Perhaps the best place to learn such skills is the 
community itself where various real-life settings provide a motivating learning ground for children to acquire social and emotional skills. Some volunteering and outdoor programmes, when they are well designed, have been shown to effectively enhance children's social and emotional skills. Successful practices tend to (a) emphasise intensive interactions between mentors and children to trigger sense of mutuality, trust, care and empathy, (b) employ experiential learning to encourage children to better cope with real-life problems and (c) stimulate children's sense of responsibility. Findings from Japan are also consistent with those from the international evidence.

Many successful programmes targeting children's social and emotional skills emphasise the importance of coherence across learning contexts.

It is not surprising to find that a number of successful programmes designed to elevate social and emotional skills involve enhancement of multiple learning contexts including family, school and community (e.g. parents receiving instructions to improve home-based activities, community resources mobilised as part of school programmes). These programmes can provide not only opportunities for children to experience enhanced learning, but also for adults (e.g. parents, teachers and mentors) to receive appropriate training. Such a holistic approach to social and emotional development may help ensure that (a) programme objectives are shared across all stakeholders, (b) social and emotional learning approaches are coherent across contexts and (c) the knowledge and skills of all care providers are augmented.

Social and emotional learning may not only be useful for disadvantaged children but also among other population groups.

A number of successful intervention programmes have been designed to enhance social and emotional skills among the disadvantaged population including low-income, low-educated and single-parent families. However, there is also evidence showing that show that social and emotional learning can be beneficial for other population groups.

Social and emotional learning may not only be useful for young children but also among adolescents.

Some social and emotional skills are malleable from early childhood through early adulthood. A number of intervention programmes have successfully enhanced social and emotional skills and behavioural outcomes of school-aged children and adolescents. Successful programmes tend to offer ageappropriate tools and contents, as individual's needs vary across different age groups. 
Table 4.1A. Summary of results from international studies

\begin{tabular}{|c|c|c|c|c|}
\hline \multicolumn{2}{|r|}{ Domains } & Achieving goals & Working with others & Managing emotions \\
\hline \multicolumn{2}{|r|}{ Examples of social and emotional skills } & $\begin{array}{l}\text { Perseverance, motivation, self-regulation, } \\
\text { attention, self-efficacy, locus of control }\end{array}$ & $\begin{array}{l}\text { Social skills, pro-sociality, } \\
\text { cooperativeness, tolerance, empathy }\end{array}$ & $\begin{array}{l}\text { Self-esteem, self-confidence, internalising } \\
\text { and externalising behavioural problems }\end{array}$ \\
\hline \multirow{7}{*}{ 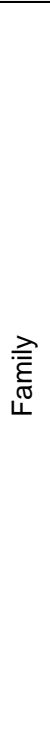 } & Direct role of parenting & & & \\
\hline & $\begin{array}{l}\text { a. Strengthening parent-child } \\
\text { relationship through family rituals } \\
\text { and routines }\end{array}$ & 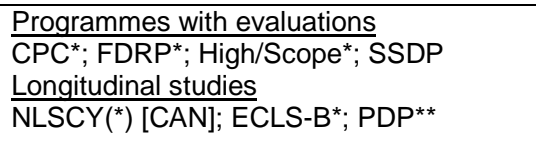 & $\begin{array}{l}\text { Programmes with evaluations } \\
\text { CPC }^{\star} ; \text { FDRP }\left({ }^{\star}\right) \\
\text { Longitudinal studies } \\
\text { ECLS-B*; EHS*; PDP }\end{array}$ & 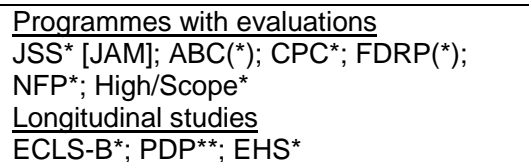 \\
\hline & Indirect family-related factors & & & \\
\hline & $\begin{array}{l}\text { a. Television viewing time and } \\
\text { contents }\end{array}$ & - & - & $\begin{array}{l}\text { Longitudinal studies } \\
\text { MCS* [GBR]; CNLSY; Huesmann et al. } \\
(2003)\end{array}$ \\
\hline & b. Parental involvement in school & $\begin{array}{l}\text { Programmes with evaluations } \\
\text { Second Step [DEU]; Al's Pals(*); CPC*; } \\
\text { High/Scope*; IY; SSDP }^{*} \text {; }\end{array}$ & $\begin{array}{l}\text { Programmes with evaluations } \\
\text { Second Step [DEU, USA]; 4Rs; Al's Pals*; } \\
\text { CSC; CPC*; IY; Peace Works*; PEF*; } \\
\text { RCCP; RULER; SDM/PS; TGV }\end{array}$ & $\begin{array}{l}\text { Programmes with evaluations } \\
\text { Second Step [DEU, NOR, USA]; 4Rs; Al's } \\
\text { Pals*; CSC; CPC*; High/Scope*; IY; } \\
\text { MMH; Peace Work**; PATHS*; PAs; } \\
\text { RCCP; SDM/PS; Tols of Mind* }\end{array}$ \\
\hline & $\begin{array}{l}\text { c. Household socio-economic } \\
\text { background }\end{array}$ & - & $\begin{array}{l}\text { Intervention studies } \\
\text { NLSCY }\left(^{*}\right)[C A N] \\
\text { Longitudinal studies } \\
\text { ECLS-K }\end{array}$ & $\begin{array}{l}\text { Intervention studies } \\
\left.\text { NLSCY }{ }^{\star}\right)[\mathrm{CAN}] \\
\text { Longitudinal studies } \\
\text { ECLS-K; } \mathrm{MCS}^{*}[\mathrm{GBR}]\end{array}$ \\
\hline & d. Maternal mental health & - & LCLS-K & $\begin{array}{l}\text { Longitudinal studies } \\
\text { MCS* [GBR]; NLSY; NICHD (1999); } \\
\text { Intervention programmes } \\
\text { STAR*D-Child study }\end{array}$ \\
\hline \multirow{4}{*}{$\begin{array}{l}\bar{O} \\
\text { o } \\
\text { ¿ }\end{array}$} & \multicolumn{4}{|l|}{ Direct role of classroom instruction } \\
\hline & $\begin{array}{l}\text { a. Specific lessons targeting social } \\
\text { and emotional skills }\end{array}$ & $\begin{array}{l}\text { Programmes with evaluations } \\
\text { Second Step [DEU]; Competent Kids; } \\
\text { CPC*; ICPS }(*) ; \text { IY }\end{array}$ & $\begin{array}{l}\text { Programmes with evaluations } \\
\text { Second Step [DEU, USA]; 4Rs; CSC; } \\
\text { Competent Kids; IY; ICPS; MMH; OCP; } \\
\text { PATHS*; Peace Works; RCCP; SDM/PS; } \\
\text { TGV } \\
\text { Meta-analysis } \\
\text { Payton et al. (2008) [INT]; Durlak et al. } \\
\text { (2011) [INT] }\end{array}$ & $\begin{array}{l}\text { Programmes with evaluations } \\
\text { Second Step [DEU, NOR, USA]; 4Rs; } \\
\text { CSC; ICPS; IY; MindUP; OCP; PEF*; } \\
\text { PATHS*; Peace Works*; PA; RCCP; } \\
\text { SDM/PS; Tools of Mind* } \\
\text { Meta-analysis } \\
\text { Payton et al. (2008) [INT]; Durlak et al. } \\
\text { (2011) [INT] }\end{array}$ \\
\hline & $\begin{array}{l}\text { b. Embedding social and emotional } \\
\text { learning in core academic subjects }\end{array}$ & $\begin{array}{l}\text { Programmes with evaluations } \\
\text { Second Step [DEU]; Mindset; Al's Pals(*); } \\
\text { High/Scope*; ICPS; IY; RC; Tools of } \\
\text { Mind*; RC }\end{array}$ & $\begin{array}{l}\text { Programmes with evaluations } \\
\text { Second Step [DEU, USA]; 4Rs; Al's } \\
\text { Pals(*); CSC; High/Scope*; ICPS; IY; } \\
\text { MMH; OCP; PATHS*; Peace Works*; RC; } \\
\text { RCCP; RULER; SDM/PS; TGV }\end{array}$ & $\begin{array}{l}\text { Programmes with evaluations } \\
\text { Second Step [DEU, NOR, USA]; 4Rs; Al's } \\
\text { Pals(*); CSC; High/Scope*; ICPS; IY; } \\
\text { MindUP; OCP; PA; Peace Works*; } \\
\text { PATHS*; RC; RCCP; SDM/PS; Tools of } \\
\text { Mind* }\end{array}$ \\
\hline & c. Peer support approaches & - & $\frac{\text { Programmes with evaluations }}{\text { 4Rs (peer mediation): CSC; RCCP (peer }}$ & $\frac{\text { Programmes with evaluations }}{\text { 4Rs (peer mediation): CSC }}$ \\
\hline
\end{tabular}


EDU/WKP(2015)10

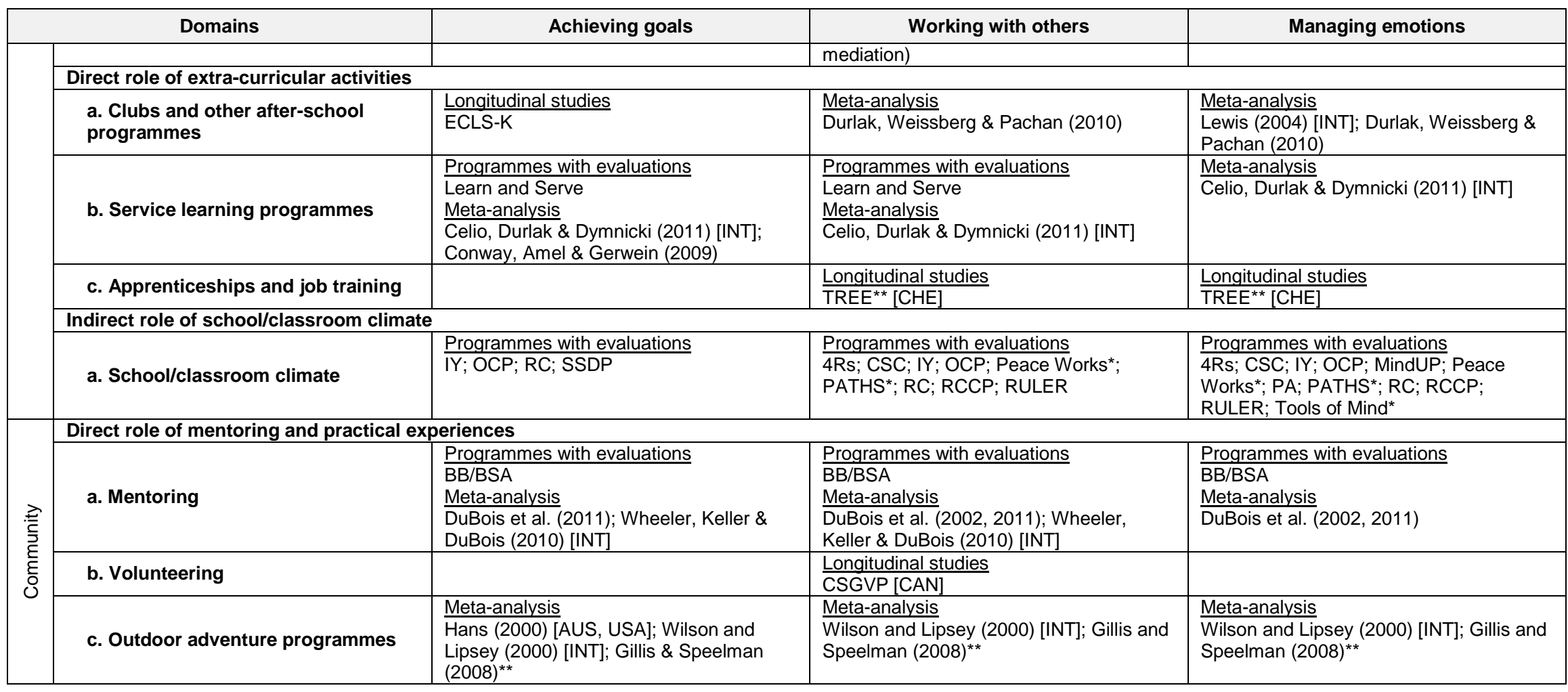

Note: * Early childhood; $\left({ }^{*}\right)$ Early childhood and childhood; ** Adolescence and adulthood

The country is indicated in square brackets when the study uses data from a non-United States country. [INT] refers to a meta-analysis covering studies from multiple countries.

ABC: Abecedarian Programme; BB/BSA: Big Brothers/Big Sisters of America; CSC: Caring School Community; CPC: Chicago Child-Parent Center; ECLS-K: Early Childhood Longitudinal Study, Kindergarten cohort; EHS: National Early Head Start Research and Evaluation Project (including EHS Father Study's Project); FDRP: Syracuse Family

Development Research Program; ICPS: I Can Problem Solve; JSS: IY: Incredible Years ${ }^{\circledR}$; Jamaican Supplementation Study; MCS: Millennium Cohort Study; MMH: Michigan Model for Health; NLSCY: National Longitudinal Survey of Children and Youth; NLSY: National Longitudinal Survey of Youth; OCP: Open Circle Program; PA: Positive Action; PATHS: Promoting Alternative Thinking Strategies; PDP: Pathways to Desistance Project; RCCP: Resolving Conflict Creatively Program; RC: Responsive Classroom; RULER: RULER Approach; SDM/PS: Social Decision Making/Problem Solving SSDP: Seattle Social Development Project; TGV: Too Good for Violence; TREE: Transitions from Education to Employment 
Table 4.1B. Summary of results from Japanese studies

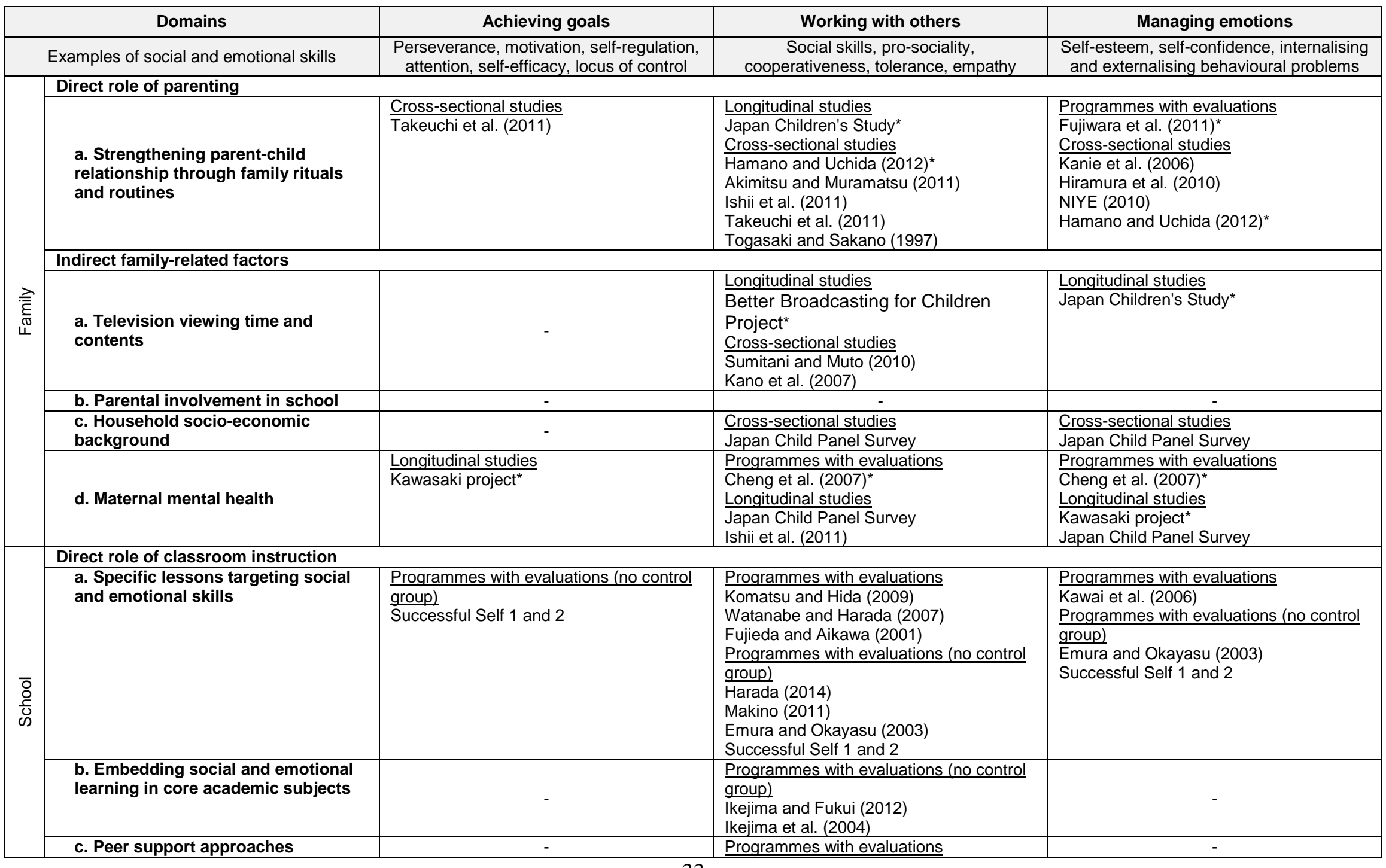


EDU/WKP(2015)10

\begin{tabular}{|c|c|c|c|c|}
\hline \multicolumn{2}{|r|}{ Domains } & \multirow{2}{*}{ Achieving goals } & Working with others & \multirow{2}{*}{ Managing emotions } \\
\hline & & & Japanese Peer Support Program & \\
\hline & \multicolumn{4}{|l|}{ Direct role of extra-curricular activities } \\
\hline & $\begin{array}{l}\text { a. Clubs and other after-school } \\
\text { programmes }\end{array}$ & - & $\begin{array}{l}\text { Cross-sectional studies } \\
\text { Aoki (2005) }\end{array}$ & - \\
\hline & c. Apprenticeships and job training & - & - & - \\
\hline & \multicolumn{4}{|l|}{ Indirect role of school/classroom climate } \\
\hline & a. School/classroom climate & - & $\begin{array}{l}\text { Cross-sectional studies } \\
\text { Takahashi, Kawashima and Yoshikawa } \\
(2010) \\
\text { Programmes with evaluations } \\
\text { Komatsu and Hida (2009) } \\
\text { Fujieda and Aikawa (2001) }\end{array}$ & $\begin{array}{l}\text { Cross-sectional studies } \\
\text { Udagawa and Shimoda (2013) }\end{array}$ \\
\hline \multirow{4}{*}{ 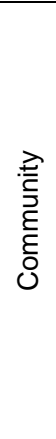 } & \multicolumn{4}{|c|}{ Direct role of mentoring and practical experiences } \\
\hline & a. Mentoring & $\begin{array}{l}\text { Programmes with evaluations (no control } \\
\text { group) } \\
\text { Kurita (2014) }\end{array}$ & $\begin{array}{l}\text { Programmes with evaluations (no control } \\
\text { group) } \\
\text { Kurita (2014) }\end{array}$ & $\begin{array}{l}\text { Programmes with evaluations (no contro } \\
\text { group) } \\
\text { Kurita (2014) }\end{array}$ \\
\hline & b. Volunteering & $\begin{array}{l}\text { Programmes with evaluations (no control } \\
\text { group) } \\
\text { Baba, Shima and Oya (2006) }\end{array}$ & $\frac{\text { Cross-sectional studies }}{\text { Midzuno and Kato (2007) }}$ & $\begin{array}{l}\text { Longitudinal studies } \\
\text { NIYE (2010) (retrospective) }\end{array}$ \\
\hline & c. Outdoor adventure programmes & $\begin{array}{l}\text { Programmes with evaluations (no control } \\
\text { group) } \\
\text { Kataoka et al. (2011) } \\
\text { Yasunami et al. (2006) } \\
\text { Nakagawa et al. (2005) } \\
\text { Ihara et al. (2004) }\end{array}$ & $\begin{array}{l}\text { Programmes with evaluations (no control } \\
\text { group) } \\
\text { Nakagawa et al. (2005) }\end{array}$ & - \\
\hline
\end{tabular}

Note: * Early childhood; (*) Early childhood and childhood; ** Adolescence and adulthood 


\section{Implications for families and school}

The evidence presented in this paper, while being not exhaustive, provides useful implications for parents and teachers to reflect on their approaches to children's social and emotional development. The following summarises the key messages:

- Schools interested in introducing activities to develop children's social and emotional skills may benefit from considering interactive, proactive, reflective, practical, intentional and experiential form of learning. This does not necessarily involve major curricular reform or introduction of new social and emotional learning classes. Some successful programmes have introduced creative approaches in existing curricular activities (e.g. solving maths problems in a group, improving the classroom climate in which students feel open to express their views and challenge particular ideas, models and theories). Extra-curricular activities can also provide alternative and/or complementary means to enhance the effectiveness of curricular approaches.

- Schools that already have in place social and emotional learning programmes may benefit from reviewing whether (a) teachers have sufficient skills to guide the learning process; (b) parents are well informed about the programme and have the capacity to provide socioemotionally nurturing environment at home; and (c) learning contexts across the school, family and the community are broadly consistent. They can also reflect if they can learn from other successful programmes.

- Parents interested in further fostering children's social and emotional skills may benefit from strengthening parent-child relationship while respecting children's autonomy. Family rituals and routines, such as reading books and having meals together with their children, may help stimulate children's social and emotional as well as cognitive skills.

- Parents may consider encouraging children to participate in community programmes and learn from the community. The community, for instance through its volunteering and outdoor programmes, offers an attractive environment for children to learn how to communicate with others, ways to deal with real-life situations, and ways to be responsible for managing their own lives.

- Teachers and parents may benefit from making joint-efforts to nurture children's social and emotional skills, and to regularly inform each other activities and progress made. The success of school-based efforts may hinge on the continuity of social and emotional development taking place at home. Parenting practices at home could be more effective if parents are well informed about children's behaviours and learning activities at school. Well-designed school-based training programmes can help establish such a holistic approach.

\section{Implications for future research in Japan}

Some of the existing evidence on social and emotional skills are powerful and provide useful insights for parents and teachers to improve ongoing practices. However, most of them are based on programmes and micro-data from the United States, and there is paucity of evidence from other countries including Japan. The international research community may also usefully continue their efforts to expand studies based on a range of rigorous evaluation of intervention programmes and on large-scale longitudinal data that cover different population groups. What are the implications for future research in Japan in light of the limited number and scope of existing Japanese evidence? This paper suggests that further efforts could be made in the following areas: 
Collecting and better exploiting micro-data on a range of social and emotional skills

There still appears a shortage of micro-data and empirical evidence that shed light on the developmental pathways of social and emotional skills in Japan. Although social and emotional skills are important predictors of social and economic outcomes, a majority of micro-data available in Japan tracks only students' academic skills. Even among those studies measuring social and emotional skills, many of them use measurement instruments that are noisy and biased. It would be useful to consider refining measures of social and emotional skills and applying them to research. Moreover, longitudinal data can be useful for understanding the impact of learning contexts on skills, as well as the impact of skills on longterm outcomes.

\section{Evaluating effectiveness of interventions in raising social and emotional skills}

Schools and community organisations are increasingly introducing programmes with the aim to improve children's social and emotional skills. While this paper has identified a number of promising school-based and community-based programmes in Japan, they were not necessarily accompanied by quality evaluation schemes. Intervention programmes that are specifically designed to be precisely assessed (e.g. randomised control trials) can provide invaluable information for education policies and practices. Interventions integrating appropriate data collection and analysis in the programme design are expected to expand. 


\section{REFERENCES}

Aber, J.L. et al. (1998), "Resolving conflict creatively: Evaluating the developmental effects of a schoolbased violence prevention program in neighborhood and classroom context", Development and Psychopathology, Vol. 10, pp.187-213.

Aber, J.L., J.L. Brown and S.M. Jones (2003), "Developmental trajectories toward violence in middle childhood: Course, demographic differences, and response to school-based intervention”, Developmental Psychology, Vol. 39, pp. 324-348.

Akimitsu, K. and Y. Muramatsu (2011), “The influence of fathers' involvement on school-aged children's sociability”, Hyogo University of Teacher Education Journal, Vol. 38, pp. 51-61.

Ando, M. (2010), "Psychoeducational program to prevent emotional and behavioral problems among junior high school students: Outcome evaluation for Successful Self 2”, Bulletin of Graduate School of Education, Okayama University, Vol. 144, pp. 27-37.

Ando, J. et al. (2006), "The Tokyo Twin Cohort Project: Overview and initial findings”, Twin Research and Human Genetics, Vol. 9/6, pp. 817-826.

Ando, M. (2008), "Psychoeducational approach to prevent emotional and behavioral problems among fourth graders in an elementary school”, Bulletin of Research and Development Center for Educational Practice, Okayama University, Vol. 8/1, pp. 89-98.

Anme, T. et al. (2012), “Center-based child extended care: Implications for young children's development in a five-year follow-up”, Sociology Mind, Vol. 2/4, pp. 435-440.

Anme, T. et al. (2010), “Interaction Rating Scale (IRS) as an evidence-based practical index of children's social skills and parenting”, Journal of Epidemiology, Vol. 20, pp. 419-426.

Anme, T. et al. (2007), "The validity and reliability of Interaction Rating Scale (IRS): Characteristics for children with behavioral or environmental difficulties”, Japanese Journal of Human Sciences of Health-Social Services, Vol. 14/1, pp. 23-31.

Anme, T. and J. Oh (2000), "Evaluation of child night care in nursery", Japanese Journal of Human Sciences of Health-Social Services, Vol. 7/1, pp. 7-18. Aoki, K. (2005), "Social skills of high school athletes and its correlates”, Journal of National Olympics Memorial Youth Center, Vol. 5, pp. 25-34.

Aoki, T. et al. (2013), "The effects of peer mediation program compact on elementary students: From the point of view of self-efficacy and school adjustment", Bulletin of the Graduate School of Education, Hiroshima University, Part I, Learning and Curriculum Development, Vol. 62, pp. 1-7.

Aoki, T. et al. (2007), "The influence of parenting attitudes and everyday activities over social skills and the sense of well-being in elementary school students”, Bulletin of the Graduate School of Education, Hiroshima University, Part I, Learning and Curriculum Development, Vol. 56, pp. 21-28. Araki, E., T. Okamura and H. Hamatani (2007), "The effect of activities for effective processing in adventure education program on participant's personal development”, Japan Outdoor Education Journal, Vol. 11/1, pp. 37-50. 
Baba, Y., K. Shima and K. Oya (2006), “A consideration on students' volunteer activities and changes on their social skills (Saga Junior College)”, Journal of Nishikyushu University \& Saga Junior College, Vol. 36, pp. 155-162.

Belfield, C. et al. (2015), The Economic Value of Social and Emotional Learning, Center for Benefit-Cost Studies in Education, Teachers College, Columbia University.

Benesse Corporation (2014), Dai-1-kai Youjiki no Katei Kyouiku Chousa / Judan Chousa (3-saiji - 4-saiji) [The longitudinal study on home education during early childhood: the first wave (three- to fouryear-olds)], http://berd.benesse.jp/up_images/textarea/research3684_paper.pdf (accessed on 10 January 2015).

Bolli, T. and S. Hof (2014), "The impact of apprenticeship training on personality traits: an instrumental variable approach”, KOF Working Papers No. 350.

Brackett, M.A. et al. (2012), "Enhancing academic performance and social and emotional competence with the RULER Feeling Words Curriculum”, Learning and Individual Differences, Vol. 22, pp. 218-224.

Brock, L.L. et al. (2008), "Children's perceptions of the social environment and social and academic performance: A longitudinal analysis of the Responsive Classroom approach”, Journal of School Psychology, Vol. 46, pp. 129-149.

Carneiro, P.M. and J.J. Heckman (2003), “Human capital policy”, in Inequality in America: What Role for Human Capital Policy?, J.J. Heckman and A.B. Krueger (eds.), MIT Press, Cambridge, MA.

Celio, C.I., J. Durlak and A. Dymnicki (2011), “A meta-analysis of the impact of service-learning on students”, Journal of Experiential Education, Vol. 34/2, pp. 164-181.

Cheng, S. et al. (2010), “Early television exposure and children's behavioral and social outcomes at age 30 months”, Journal of Epidemiology, Vol. 20/Supplement II, pp. S482-S489.

Cheng, S. et al. (2010), "Comparison of factors contributing to developmental attainment of children between 9 and 18 months”, Journal of Epidemiology, Vol. 10/Supplement II, pp. S452-S458.

Cheng, S. et al. (2009), “Contribution of parenting factors to the developmental attainment of 9-month-old infants: results from the Japan Children’s Study”, Journal of Epidemiology, Vol. 19/16, pp. 319-327.

Cheng, S. et al. (2007), "The effectiveness of early intervention and the factors related to child behavioural problems at age 2: A randomized controlled trial”, Early Human Development, Vol. 83/10, pp. 683691.

Christakis, D.A. et al. (2004), "Early television exposure and subsequent attentional problems in children", Pediatrics, Vol. 113/4, pp. 708-713.

Collaborative for Academic, Social, and Emotional Learning (2012), CASEL Guide: Effective Social and Emotional Learning Programs - Preschool and Elementary School Edition, Collaborative for Academic, Social, and Emotional Learning, Chicago, IL.

Covay, E. and W. Carbonaro (2010), "After the bell: Participation in extracurricular activities, classroom behavior, and academic achievement”, Sociology of Education, Vol. 83/1, pp. 20-45. 
Cunha, F. and J.J. Heckman (2008), "Formulating, identifying and estimating the technology of cognitive and noncognitive skill formation”, Journal of Human Resources, Vol. 43, pp. 738-782.

Cunha, F. and J.J. Heckman (2007), “The technology of skill formation”, American Economic Review, Vol. 97/2, pp. 31-47.

Dee, T.S. and M.R. West (2011), “The non-cognitive returns to class size”, Educational Evaluation and Policy Analysis, Vol. 33/1, pp. 23-46.

Durlak, J.A., R.P. Weissberg and M. Pachan (2010), “A meta-analysis of after-school programs that seek to promote personal and social skills in children and adolescents", American Journal of Community Psychology, Vol. 45, pp. 294-309.

El Nokali, N.E., H.J. Bachman and E. Votruba-Drzal (2010), "Parent involvement and children's academic and social development in elementary school”, Child Development, Vol. 81/3, pp. 988-1005.

Emura, R.A. and T. Okayasu (2003), "Classroom-based social skills education: Junior high school students”, Japanese Journal of Educational Psychology, Vol. 51/3, pp. 339-350.

Feist, G.J. (1998), “A meta-analysis of personality in scientific and artistic creativity”, Personality and Social Psychology Review, Vol. 2/4, pp. 290-309.

Fletcher, J. and B. Wolfe (2012), "The importance of family income in the formation and evolution of noncognitive skills in childhood”, Centre for Economic Policy Research Discussion Paper Series, Vol. 665.

Frank, R.G. and E. Meara (2009), "The Effect of Maternal Depression and Substance Abuse on Child Human Capital Development”, National Bureau of Economic Research Working Paper Series, Vol. No. 15314.

Fujieda, S. and A. Aikawa (2001), “Classwide social skills training: Elementary school”, Japanese Journal of Educational Psychology, Vol. 49/3, pp. 371-381.

Fujiwara, T., N. Kato and M.R. Sanders (2011), "Effectiveness of group Positive Parenting Program (Triple P) in changing child behavior, parenting style, and parental adjustment: An intervention study in Japan”, Journal of Child and Family Studies, Vol. 20/6, pp. 804-813.

Gillis, H.L. and E. Speelman (2008), “Are challenge (ropes) courses an effective tool? A meta-analysis”, Journal of Experiential Education, Vol. 31/2, pp. 111-135.

Gregg, P. et al. (2005), "The effects of a mother's return to work decision on child development in the UK”, The Economic Journal, Vol. 115/501, pp. F48-F80.

Grossman, D.C. et al. (1997), "Effectiveness of a violence prevention curriculum among children in elementary school: A randomized controlled trial”, Journal of American Medical Association, Vol. 277, pp. 1605-1611.

Gutman, L.M. and I. Schoon (2013), The Impact of Non-Cognitive Skills on Outcomes for Young People: Literature Review, Institute of Education, University of London, London.

Hall, M. et al. (2009), Caring Canadians, Involved Canadians: Highlights from the 2007 Canada Survey of Giving, Volunteering and Participating, Statistics Canada, Ottawa. 
Halpern, D.F. (1998), “Teaching critical thinking for transfer across domains: Dispositions, skills, structure training, and metacognitive monitoring”, American Psychologist, Vol. 53/4, pp. 449-455.

Hamano, T. and N. Uchida (2012), "Youjiki ni okeru yomikaki nouryoku no kakutoku to sono kankyou youin no eikyou ni kansuru kokusai hikaku kenkyuu" [International comparative research on literacy acquisition process during early childhood and effects of environmental factors on it], Ochanomizu Research Center for Human Development and Education Annual Report, Vol. 4, pp. 13-41.

Hans, T. (2000), “A meta-analysis of the effects of adventure programming on locus of control”, Journal of Contemporary Psychotherapy, Vol. 30/1, pp. 33-60.

Harada, M. (2006), Next Generation Support and Transfiguration of Parenting: Child Abuse Prevention and Parenting Site in Hyogo Report, Nagoya University Press, Nagoya.

Harada, E. (2014), “The practice of social skills training in the first grade students”, Journal of Tokyo University of Information Sciences, Vol. 17, pp. 1-11.

Hattori, S. and M. Harada (1991), Nyuuyouji no Shinshin Hattatsu to Kankyou: Osaka Report to Seishin Igakuteki Shiten [Infant Psychophysical Development and Environment: Osaka Report and Psychiatric Perspective], Nagoya University Press, Nagoya.

Herrera, C. et al. (2007), Making a Difference in Schools: The Big Brothers Big Sisters School-based Mentoring Impact Study, Public/Private Ventures, Philadelphia, PA.

Hille, A. and J. Schupp (2015), "How learning a musical instrument affects the development of skills”, Economics of Education Review, Vol. 44, pp. 56-82.

Hiramura, H. et al. (2010), "Understanding externalizing behavior from children's personality and parenting characteristics”, Psychiatry Research, Vol. 175/1-2, pp. 142-147.

Holsen, I., B.H. Smith and K.S. Frey (2008), "Outcomes of the social competence program Second Step in Norwegian elementary schools”, School Psychology International, Vol. 29, pp. 71-88.

Horikawa, R. and K. Shibayama (2014), "The effect of a class-sized psychological education program for self-esteem improvement and anxiety reduction in children”, Memoirs of the Faculty of Education, Kumamoto University, Vol. 63, pp. 133-140.

Huerta, M.C. et al. (2013), “Fathers' leave, fathers' involvement and child development: Are they related? Evidence from four OECD countries”, OECD Social, Employment and Migration Working Papers, No. 140, OECD Publishing, Paris, http://dx.doi.org/10.1787/5k4dlw9w6czq-en.

Ihara, K. et al. (2004), "The effects of adventure education program on general self-efficacy of early adolescents”, Japan Outdoor Education Journal, Vol. 7/2, pp. 13-22.

Ikejima, T. and A. Fukui (2012), "Peer support program for cooperative learning”, Bulletin of School of Professional Development in Education, Nara University of Education, Vol. 4, pp. 55-60.

Ikejima, T. et al. (2005), “The development of lesson plans "the activities of the conflict resolution” for getting the formative ability of human relations in elementary school for sixth", Bulletin of Center for Educational Research and Development, Vol. 14, pp. 133-139. 
Ikejima, T. et al. (2004), "A study on the activities and effects of classwide peer-support program in elementary school for fifth”, Bulletin of Center for Educational Research and Development, Vol. 13, pp. 127-136. Ishii, Y. et al. (2011), "Maternal stress, parenting factors, experiences in day care, and developmental outcomes in 5-year-old children in day care in Japan”, Japanese Journal of Human Sciences of Health-Social Services, Vol. 18/1, pp. 148-159.

John, O.P. and S. Srivastava (1999), “The Big Five trait taxonomy: History, measurement, and theoretical perspectives”, Handbook of Personality: Theory and Research, L.A. Pervin and O.P. John (eds.), 2nd ed. Guilford Press, New York, NY, pp. 102-139.

Jones, S.M., J.L. Brown and J.L. Aber (2011), "Two-year impacts of a universal school-based socialemotional and literacy intervention: An experiment in translational developmental research”, Child Development, Vol. 82, pp. 533-554.

Kan, M. (2012), "Effects of maternal employment on adolescent behavior and academic outcomes: Evidence from Japanese micro data”, Center for Intergenerational Studies (CIS) Discussion Paper Series, Vol. 541.

Kanie, N., K. Iwasaki and K. Makino (2006), “Effects of parent’s academic background and child’s gender on educational resources in the family: in relation to child's perception of family atmosphere and self-esteem", The 21st Century College of Education (COE) Program Studies of Human Development from Birth to Death Research Monograph: Studies of Human Development, Ochanomizu University, Tokyo, pp. 105-108.

Kano, A. et al. (2007), "Relation of television and video watching time to development of children aged three and a half years”, The Journal of the Japan Pediatric Society, Vol. 111/3, pp. 454-461.

Kataoka, M. et al. (2011), "Girl scout keiken ga chukousei joshi no jiko kouteikan ni ataeru eikyou" [Effects of girl scout experience on self-esteem of junior high and high school girls], Annual Convention of the Japanese Association of Educational Psychology, Vol. 53, pp. 547.

Kautz, T., et al. (2014), "Fostering and measuring skills: Improving cognitive and non-cognitive skills to promote lifetime success", OECD Education Working Papers, No. 110, OECD Publishing, Paris, http://dx.doi.org/10.1787/5jxsr7vr78f7-en.

Kawai, E. et al. (2006), "Evaluation of a training program to prevent deterioration of children's self-esteem: Fostering children's skills in arguing against self-defeating cognitions about negative events", Japanese Journal of Educational Psychology, Vol. 54/1, pp. 112-123.

Keio University Joint Research Center for Panel Studies (2008), Nihon Kodomo Panel Chousa no Gaiyou [Outline of the Japan Child Panel Survey], http://www.pdrc.keio.ac.jp/open/post.html (accessed on 10 January 2015).

Kiernan, K.E. and M.C. Huerta (2008), "Economic deprivation, maternal depression, parenting and children's cognitive and emotional development in early childhood", The British Journal of Sociology, Vol. 59/4, pp. 783-806.

Kikawada, M. et al. (2006), "Maternal stress and implications for the development of four-year-old children placed in center-based care”, Japanese Journal of Human Sciences of Health-Social Services, Vol. 12/2, pp. 15-24. 
Komatsu, H. and M. Hida (2009), “The effect of experience of group activity upon children's social skills: Self-consciousness, evaluation of classroom, and social skills", Bulletin of Center for Research and Development of Education, Fukushima University, Vol. 7, pp. 85-92.

Komatsu, H. and M. Hida (2008), "The influences of children's self-evaluation and evaluation of classroom”, Bulletin of Center for Research and Development of Education, Fukushima University, Vol. 5, pp. 9-16.

Kurita, A. (2014), “The consideration about contents and effects of mental friends' activity: A investigation the actual situation for child consultation center and a case study of mental friend”, Bulletin of Teikyo University Junior College, Vol. 18, pp. 175-183.

Lewis, C.P. (2004), The Relation between Extracurricular Activities with Academic and Social Competencies in School Age Children: A Meta-Analysis. Texas A\&M University.

Lian, T. et al. (2011), "Predictors of working mother's parenting practices in infancy on the competences of vocabulary and communication of two-year-old children”, Japanese Journal of Human Sciences of Health-Social Services, Vol. 18/1, pp. 94.

Lubart, T.I. (1994), Creativity in Thinking and Problem Solving, ed. R.J. Sternberg, Academic Press, San Diego, CA.

Lucas-Thompson, R.G., W.A. Goldberg and J. Prause (2010), "Maternal work early in the lives of children and its distal associations with achievement and behavior problems: A meta-analysis", Psychological Bulletin, Vol. 136/6, pp. 915-942.

Makino, K. (2011), “A development of the communication skills training for junior high school students (4): The effects of communication skills training on self-evaluation", Journal of Business Administration and Information, Setsunan University, Vol. 18/2, pp. 107-118.

Melchior, A. et al. (1999), Summary Report: National Evaluation of Learn and Serve America, Brandeis University, Waltham, MA.

MEXT (2005), FY2004 White Paper on Education, Culture, Sports, Science and Technology, MEXT, Tokyo.

Midzuno, K. and T. Kato (2007), "Do volunteer activities effect psychological growth of participants?: An examination on the basis of relations among experience of volunteer activities, personality traits, social skills, senses of fulfillment, and views of activities”, The Seisen Review, Vol. 15, pp. 141-156.

Milligan, K. and M. Stabile (2011), "Do child tax benefits affect the well-being of children? Evidence from Canadian child benefit expansions”, American Economic Journal: Economic Policy, Vol. 3/3, pp. 175-205.

Milligan, K. and M. Stabile (2009), “Child benefits, maternal employment, and children's health: Evidence from Canadian child benefit expansions”, American Economic Review, Vol. 99/2, pp. 128-32.

Mimizuka, H., J. Wang and Y. Tarumi (2012), “Japan Educational Longitudinal Study”, Ochanomizu University Research Center for Human Development and Education Annual Report, Vol. 4, pp. 5961. 
Muñiz, E.I., E.J. Silver and R.E.K. Stein (2014), "Family routines and social-emotional school readiness among preschool-age children”, Journal of developmental and behavioral pediatrics, Vol. 35/2, pp. 93-99.

Nakagawa, M. et al. (2005), "The effects of long-term and short-term camping on IKIRU CHIKARA (Zest for Living) of early adolescents”, Japan Outdoor Education Journal, Vol. 8/2, pp. 31-43.

National Institute for Educational Policy (2008), "Shakaisei no Kiso" o Hagukumu "Kouryuu Katsudou”, "Taiken Katsudou": "Hito to Kakawaru Yorokobi" o Motsu Jidou Seito ni ["Exchange Activities" and "Experiential Activities" to Foster "Basic Sociality": Towards Students Who Have "Joy in Engaging with Others"], National Institute for Educational Policy Research Guidance and Counseling Research Center, Tokyo.

National Institution for Youth Education (2010), Kodomo no Taiken Katsudo no Jittai ni Kansuru Chosa Kenkyu Hokokusho [Research Report on the Actual Conditions of Children's Experience Programmes], National Institution for Youth Education, Tokyo.

NHK Broadcasting, Culture Research Institute (2010), Television and Japanese Children: A Longitudinal Study from Zero to Twelve - Interim Report from Zero to Five, NHK Broadcasting, Culture Research Institute, Tokyo.

NICHD (1999), "Chronicity of maternal depressive symptoms, maternal sensitivity, and child functioning at 36 months”, Developmental Psychology, Vol. 35, pp. 1297-1310.

Noelke, C. (forthcoming), The Effects of Learning Contexts on Skills, OECD Publishing, Paris.

Nozaki, K. (2013), "The effect of maternal employment in early childhood on the child's later development”, in Hatarakikata to Koufukukan no Dainamizumu [Dynamism of Working Styles and a Sense of Happiness], Y. Higuchi et al. (eds.), Keio University Press, Tokyo, pp. 103-120.

OECD (2015), Skills for Social Progress: the Power of Social and Emotional Skills, OECD Skills Studies, OECD Publishing, Paris, http://dx.doi.org/10.1787/9789264226159-en.

OECD (2010), Improving Health and Social Cohesion through Education, OECD Publishing, Paris, http://dx.doi.org/10.1787/9789264086319-en.

OECD (2006), Are Students Ready for a Technology-Rich World?: What PISA Studies Tell Us. OECD Publishing, Paris, www.oecd.org/dataoecd/28/4/35995145.pdf.

Omi, R. and A. Sakamoto (2005), “Terebi sesshoku ga kodomo no ninchi nouryoku, jouhou katsuyou no jissenryoku, kougekisei, koushakaisei ni ataeru eikyou: Shougakusei o taishou to shita 2-ha panel kenkyuu" [Influence of television exposure on children's cognitive skills, practical skills to use information, aggression and pro-sociality: Two-wave panel study on elementary school students], in “The Better Broadcasting for Children” the Second-round Study Report, NHK Broadcasting Culture Research Institute, Tokyo, pp. 60-69.

Parkes, A. et al. (2013), "Do television and electronic games predict children's psychosocial adjustment? Longitudinal research using the UK Millennium Cohort Study”, Archives of Disease in Childhood.

Promising Practices Network (2014), Programs that Work, Promising Practices Network, http://www.promisingpractices.net/programs.asp (accessed on 10 January 2015). 
Rimm-Kaufman, S.E. and Y.I. Chiu (2007), "Promoting social and academic competence in the classroom: An intervention study examining the contribution of the Responsive Classroom approach”, Psychology in the Schools,Vol. 44, pp. 397-413.

Rotter, J.B. (1990), "Internal versus external control of reinforcement: A case history of a variable”, American Psychologist, Vol. 45/4, pp. 489-493.

Ruhm, C.J. (2004), “Parental employment and child cognitive development”, Journal of Human Resources, Vol. XXXIX/1, pp. 155-192.

Shaw, D.S. (2014), "Parenting programs and their impact on the social and emotional development of young children, 2nd ed.”, Encyclopedia on Early Childhood Development, http://www.childencyclopedia.com/sites/default/files/textes-experts/en/654/parenting-programs-and-their-impact-onthe-social-and-emotional-development-of-young-children.pdf (accessed on 10 January 2015).

Shibuya, A. et al. (2004) "Media bouryoku eno sesshoku, sesshoku kankyou ga kougekisei ni oyobosu choukiteki eikyou: shougakusei eno panel chousa” [Long-term influence of exposure to violence in media and exposure contexts on aggression: Panel study on elementary school students], The 45th Conference for the Japanese Society of Social Psychology, pp. 248.

Schick, A. and M. Cierpka (2005), "Faustlos: Evaluation of a curriculum to prevent violence in elementary schools”, Applied and Preventive Psychology, Vol. 11, pp. 157-165.

Shikishima, C., J. Yamashita and H. Akabayashi (2012), "Kodomo no shakaisei, tekioukan to katei haikei” [Child's social skills / quality of life and family background], in Oyako Kankei to Kakei Koudou no Dynamism [Dynamism of Parent-Child Relationship and Household Behaviour], Y. Higuchi et al. (eds.), Keio University Press, Tokyo, pp. 25.

Shinohara, R. et al. (2011), “Does a mother's praise foster her child's social competence?”, Japanese Journal of Human Sciences of Health-Social Services, Vol. 18/1, pp. 125-134.

Shinohara, R. et al. (2010), “The trajectory of children's social competence from 18 months to 30 months of age and their mother's attitude towards the praise”, Journal of Epidemiology, Vol. 20/Supplement II, pp. S441-S446.

Solomon, D. et al. (2000), “A six-district study of educational change: Direct and mediated effects of the child development project”, Social Psychology of Education, Vol. 4, pp. 3-51.

Soto, C.J. et al. (2011), “Age differences in personality traits from 10 to 65: Big-Five domains and facets in a large cross-sectional sample”, Journal of Personality and Social Psychology, Vol. 100, pp. 330348.

Steinberg, L., I. Blatt-Eisengart and E. Cauffman (2006), "Patterns of competence and adjustment among adolescents from authoritative, authoritarian, indulgent, and neglectful homes: A replication in a sample of serious juvenile offenders”, Journal of Research on Adolescence, Vol. 16, pp. 47-58.

Sugawara, M. (2011), "Media riyou jikan to kodomo no personality youin tono kankei” [Association between media use time and children's personality factors], in The Better Broadcasting for Children: the Seventh- and Eighth-rounds Follow-up Study Report, NHK Broadcasting Culture Research Institute, Tokyo, pp. 51-55. 
Sugawara, M. (2010), A Multi-Cohort Study of Social Adjustment in Childhood: From the Developmental Psychological Approach - Grants-in-Aid for Scientific Research Final Report.

Sugawara, M. (2005), "Nyuuyoujiki no shinshin no hattatsu to media sesshoku” [Mental and physical development during infancy and early childhood and contact with media], in "The Better Broadcasting for Children” the Second-round Study Report, NHK Broadcasting Culture Research Institute, Tokyo, pp. 34-49.Sugawara, M. et al. (2006), "A longitudinal study of relationships between maternal employment and child problem behaviours", The 21st Century COE Program Studies of Human Development from Birth to Death Research Monograph: Studies of Human Development, Ochanomizu University, Tokyo, pp. 45-50.

Sugawara, M. et al. (2005), "Nyuujiki no hattatsu to eizou media sesshoku: Eikyousei ni kansuru inga suitei no kanousei o sagutte" [Infant development and visual media exposure: Exploration of possibility of causal inference about the influence], Baby Science, Vol. 5, pp. 46-53.

Sugawara, M. et al. (1999), "Longitudinal relationship between maternal depression and infant temperament in a Japanese population”, Journal of Clinical Psychology, Vol. 55/7, pp. 869-880.

Sumitani, S. and T. Muto (2010), "The longitudinal influence of television programs wached in childhood on social and psychological maladjustment in puberty", Bulletin of Joetsu University of Education, Vol. 29, pp. 101-112.

Takahashi, S., Y. Kawashima and E. Yoshikawa (2010), "An examination of school group and social skills (1)”, The Seisen Review, Vol. 18, pp. 1-13.

Takahashi, Y., B.W. Roberts and T. Hoshino (2012), "Conscientiousness mediates the relation between perceived parental socialisation and self-rated health”, Psychology \& Health, Vol. 27/9, pp. 10481061.

Takeuchi, M.S. et al. (2011), "The relationship of temperament and character dimensions to perceived parenting styles in childhood: A study of a Japanese university student population”, The Open Family Studies Journal, Vol. 4, pp. 9-14.

Taki, M. (2009), Kaiteishinban Peer Support de Hajimeru Gakkou Zukuri: Shougakkou Hen [School Development with Peer Support: For Elementary School, Revised Edition], Kaneko Shobo, Tokyo.

Taki, M. (2004), Kaiteishinban Peer Support de Hajimeru Gakkou Zukuri: Chuugakkou Hen [School Development with Peer Support: For Junior High School, Revised Edition], Kaneko Shobo, Tokyo.

Tanaka, E. et al. (2010), "Implications of social competence development among eighteen month toddlers", Japanese Journal of Human Sciences of Health-Social Services, Vol. 16/1, pp. 57-66.

Tierney, J.P., J.B. Grossman and N.L. Resch (2000), Making a Difference: An Impact Study of Big Brothers Big Sisters, Public/Private Ventures, Philadelphia, PA.

Togasaki, Y. and Y. Sakano (1997), "Effects of mother's attitude for child rearing on social skills and school adaptation in elementary school children: From the point of view of the attitude for child rearing of active refusal type”, Japanese Journal of Educational Psychology, Vol. 45/2, pp. 173-182. 
Toppe, C.M., A.D. Kirsch and J. Michel (2001), Giving and Volunteering in the United States: Findings from a National Survey, INDEPENDENT SECTOR, Washington, DC.

Uchida, N. and Y. Ishida (2011), "What counts the most for early literacy acquisition?: Japanese data from the cross-cultural literacy survey of GCOE project”, Proceedings: Science of Human Development for Restructuring the "Gap Widening Society”, Vol. 13, pp. 37-44.

Udagawa, S. and Y. Shimoda (2013), "Study about relationship between classroom climate and assertive styles among elementary school students", Kyoiku Jissen Kenkyu: Bulletin of the Center for Educational Research and Practice, Toyama University, Vol. 7, pp. 15-20.

Ueno, E., Y. Miyake and E. Katsurada (2009), "Hahaoya no shuugyou ni kansuru ishiki oyobi youiku taido to kodomo no shakaiteki sukiru no kanren ni tsuite" [The association between mother's attitudes towards work and parenting attitudes and child's social skills], Annual Convention of the Japanese Association of Educational Psychology, Vol. 51, pp. 314.

Watanabe, K. (2008), Hiroshima-shi Seishounen Mentor Seido to Mentoring Undou [The Hiroshima City Mentoring Programme and Mentoring Movement], Japan Association of Lifelong Education, http://ejiten.javea.or.jp/content.php?c=TWpBeU9ERXdNUT09 (accessed on 10 January 2015).

Watanabe, K. et al. (2012), "Triangular evaluation of eclectic mentoring program: A case of Hiroshima, Japan”, IVth International Conference of Community Psychology, Universidad de Barcelona, Barcelona, pp. 301.

Watanabe, Y. and E. Harada (2007), "Effects of social skills training on social skills and self-esteem among high school students”, Bulletin of Faculty of Letters, Hosei University, Vol. 55, pp. 59-72.

Wheeler, M.E., T.E. Keller and D.L. DuBois (2010), "Review of three recent randomized trials of schoolbased mentoring: Making sense of mixed findings”, Social Policy Report, Vol. 24/3.

Wickramaratne, P. et al. (2011), "Children of depressed mothers 1 year after remission of maternal depression: findings from the STAR*D-Child study", American Journal of Psychiatry, Vol. 168/6, pp. 593-602.

Wilson, S.J. and M.W. Lipsey (2000), "Wilderness challenge programs for delinquent youth: A metaanalysis of outcome evaluations”, Evaluation and Program Planning, Vol. 23, pp. 1-12.

Winner, E., T. Goldstein and S. Vincent-Lancrin (2013), Art for Art's Sake?: The Impact of Arts Education, Educational Research and Innovation, OECD Publishing, Paris, http://dx.doi.org/10.1787/9789264180789-en.

Yamagata, Z. and JCS Group (2009), Research Report (Fiscal Year 2004-2008) on R\&D Project: Identification of Factors Affecting Cognitive and Behavioral Development of Children in Japan Based on a Cohort Study; Japan Children's Study, Research Institute of Science and Technology for Society, Tokyo.

Yamamoto, K., S. Araki and K. Kamino (2010), "Empirical study on relation between involvement in extracurricular activities and acquisition of sociality", Research Reports, Tsuyama Technical College, Vol. 52, pp. 95-100.

Yasunami, Y. et al. (2006), "The influence of program type at Hyogo Nature School on social and emotional developments in the fifth grade”, Japan Outdoor Education Journal, Vol. 9/2, pp. 31-43. 
EDU/WKP(2015)10

\section{ANNEX 1. TYPES OF STUDIES INCLUDED IN THE PAPER}

While there are a number of ways of classifying research designs, four prominent research designs relevant to this paper are listed here - experimental, cross-sectional, longitudinal and case study designs.

\section{Experimental design}

In experimental studies, investigators verify their hypotheses by randomly assigning their subjects into treatment groups and control groups. Since random assignment ensures that the probability of being assigned to the treatment group is equal for all the subjects, it is possible to assume that there is no difference between the treatment group and the control group in terms of all the conditions except the experiment condition. This assumption allows the conclusion that if there is any difference between the groups, it is caused by the intervention in the experiment.

In the United States, the experimental design has been extensively used in evaluation of educational intervention programmes. For example, the High/Scope Perry Preschool Study in the 1960s randomly assigned 123 children of three and four years old into a programme group that received a high-quality preschool programme and a comparison group who received no preschool programme. The Carolina Abecedarian Project in the 1970s randomly assigned 111 infants to either the early educational intervention group or the control group. Tennessee's Student/Teacher Achievement Ratio (STAR) project in the 1980s randomly assigned 11571 children and their teachers to small classes and large classes upon entry into kindergarten and were kept in the same track through elementary Grade 3.

However, it is not always possible to assign subjects randomly into different groups in real settings. For example, there are foreseeable ethical issues relating to manipulating the provision of educational intervention.

A quasi-experimental design is the design that takes a similar form to the experimental design in which subjects are not randomly assigned into a treatment group and a control group. For example, the Syracuse Family Development Research Program did not use random assignment and instead compared children who participated in the early childhood programme to "similar" children in other neighbourhoods.

\section{Cross-sectional design}

The cross-sectional design is typically characterised by one-time surveys. A cross-sectional design study analyses data collected more or less at the same time to examine associations between variables of interest.

Although many studies using the cross-sectional design try to address causal relationships, attention would be required when interpreting results of these studies, since the cross-sectional design does not allow credible causal conclusions. Firstly, a study with this design only indicates a relationship between variables and cannot identify the direction of the causal relationship. For example, even if there is a correlation between maternal parenting attitudes and children's social and emotional skills, it does not necessarily indicate an effect of maternal parenting attitudes. It could be that children's behaviours influence mothers' attitudes. Secondly, there is also an issue of spurious correlation or omitted variable bias. For example, even if a correlation is found between maternal parenting attitudes and children's social 
and emotional skills, it could be that both of the variables are influenced by family socio-economic characteristics and hence be correlated to each other.

\section{Longitudinal design}

The longitudinal design entails repeated observations of the same sample over time. Longitudinal design studies that track the same individuals allow estimation of potential causal relationships. Typical examples of such studies include the National Longitudinal Survey of Youth 1979 (NLYS79) in the United States and the Millennium Cohort Study (MCS) in the United Kingdom.

One of the major issues with the longitudinal design is attrition of participants. While participants drop out from a longitudinal study for various reasons, there may be an important difference between those who drop out and those who continue to participate. If the attrition rate is high, the remaining sample may not be representative of the population, which reduces reliability of research results.

\section{Case study design}

A case study investigates a contemporary phenomenon (the "case") in its real-world context. The case study design is typically used when main research questions are "when" and "how" and require extensive and in-depth description of the phenomenon. Case studies are often small scale and their results may not be applied to a wider population. However, they could offer a potential explanation for complex phenomena. 
ANNEX 2. SOCIAL AND EMOTIONAL OUTCOMES OF SCHOOL-BASED INTERVENTION PROGRAMMES

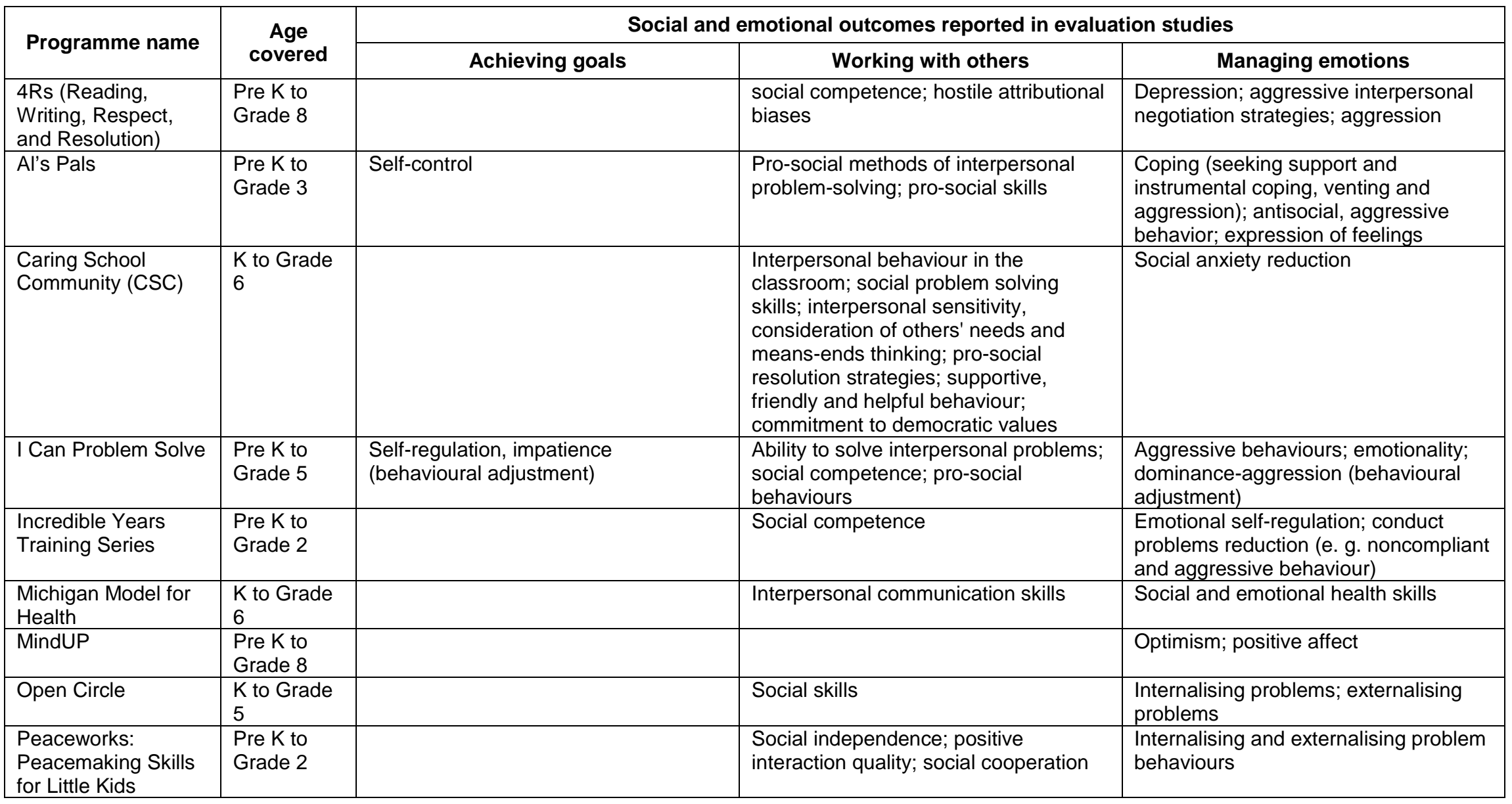


EDU/WKP(2015)10

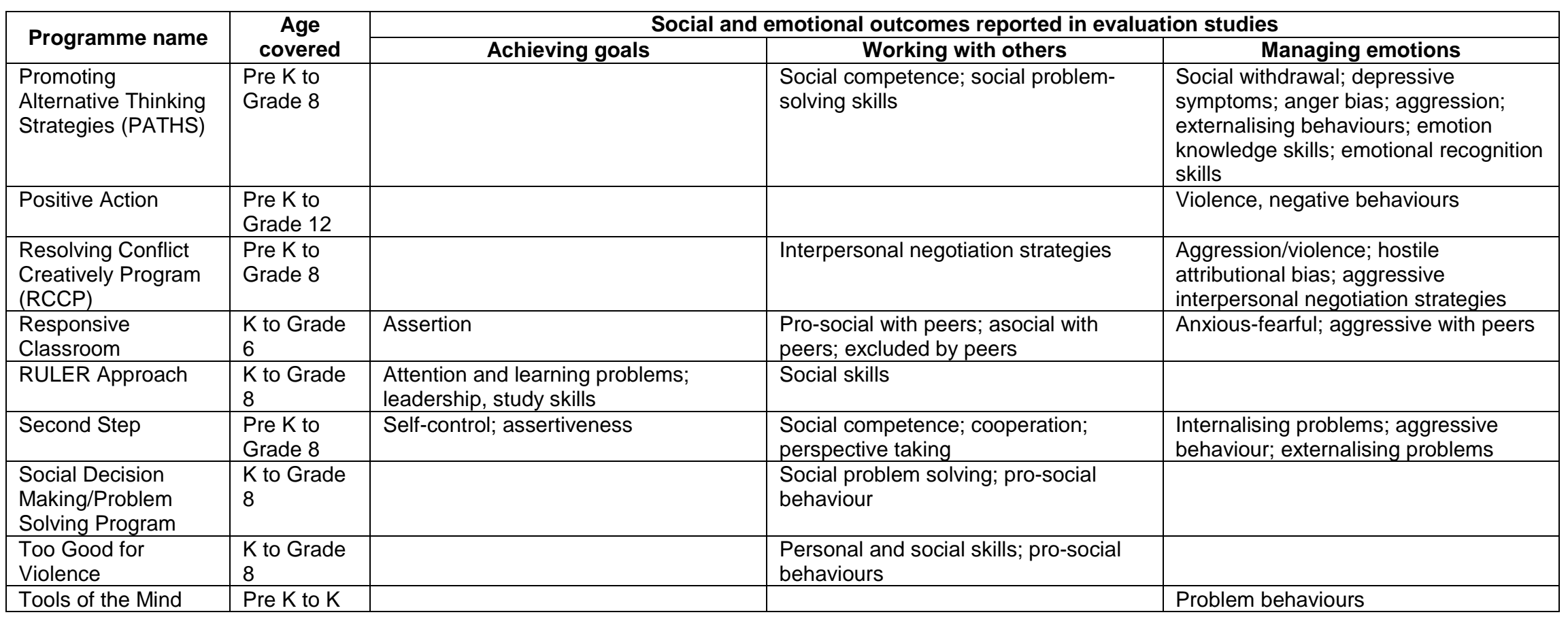

Source: Collaborative for Academic, Social, and Emotional Learning (2012) 


\section{ANNEX 3. LONGITUDINAL DATASETS WITH SKILL MEASUREMENT IN JAPAN}

\begin{tabular}{|c|c|c|c|c|c|}
\hline Survey & $\begin{array}{l}\text { Year } \\
\text { started }\end{array}$ & Sample at recruitment & $\begin{array}{l}\text { Age at } \\
\text { recruitment }\end{array}$ & $\begin{array}{l}\text { Response } \\
\text { rate at } \\
\text { recruitment }\end{array}$ & Description \\
\hline $\begin{array}{l}\text { Longitudinal study } \\
\text { on education at } \\
\text { home from early } \\
\text { childhood through } \\
\text { the first year of } \\
\text { elementary school }\end{array}$ & 2012 & $\begin{array}{l}5,016 \text { mothers with children } \\
\text { aged from } 3 \text { to } 7 \text { from all } \\
\text { over Japan participated in } \\
\text { the cross-sectional survey in } \\
2012 \text {. Among them } 1,460 \\
\text { mothers agreed to } \\
\text { participate in the longitudinal } \\
\text { study. }\end{array}$ & 3-7 years old & $\begin{array}{l}35.8 \% \\
(5,016 \text { out of } \\
14,000)\end{array}$ & $\begin{array}{l}\text { This longitudinal study has been conducted by the Benesse } \\
\text { Educational Research and Development Institute, with the aim of } \\
\text { understanding the relationship between education at home from } \\
\text { early childhood through the first year of elementary school and } \\
\text { children's development, including how children learn, what } \\
\text { mothers with elementary school-age children feel children should } \\
\text { acquire during early childhood, parental involvement and } \\
\text { perception. Self-administered questionnaires are sent by mail } \\
\text { once a year, which survey issues including how children use } \\
\text { their time, how children prepare for learning, mothers' } \\
\text { retrospective reports on children's early childhood, maternal } \\
\text { involvement, maternal view for education, paternal division of } \\
\text { roles, satisfaction with early childhood institutions and schools, } \\
\text { and reading to children (Benesse Corporation, 2014). }\end{array}$ \\
\hline $\begin{array}{l}\text { Japan Child Panel } \\
\text { Survey }\end{array}$ & $\begin{array}{l}2010 \\
\text { (JHPS) } \\
\text { and } \\
2011 \\
\text { (KHPS) }\end{array}$ & $\begin{array}{l}\text { JHPS cohort: } 457 \text { children } \\
\text { from the participating } \\
\text { households of the Japan } \\
\text { Household Panel Survey } \\
\text { (JHPS) } \\
\text { KHPS cohort: } 657 \text { children } \\
\text { from the Keio Household } \\
\text { Panel Survey (KHPS) }\end{array}$ & $\begin{array}{l}6-15 \text { years } \\
\text { old }\end{array}$ & $\begin{array}{l}48.4 \% \\
\text { (JHPS); } \\
59.5 \% \\
\text { (KHPS) }\end{array}$ & $\begin{array}{l}\text { This survey started as an appurtenant survey to household panel } \\
\text { surveys that have been carried out by Keio University, for the } \\
\text { purpose of investigating the situation of child-bearing at each } \\
\text { household and the status of learning by children themselves. } \\
\text { Questionnaire surveys have been conducted on the panel } \\
\text { surveys' participating households with children in elementary or } \\
\text { junior high school. The questionnaires include measures of both } \\
\text { cognitive and social and emotional skills (Keio University Joint } \\
\text { Research Center for Panel Studies, 2008). }\end{array}$ \\
\hline
\end{tabular}




\begin{tabular}{|c|c|c|c|c|c|}
\hline Survey & $\begin{array}{l}\text { Year } \\
\text { started }\end{array}$ & Sample at recruitment & $\begin{array}{c}\text { Age at } \\
\text { recruitment }\end{array}$ & $\begin{array}{l}\text { Response } \\
\text { rate at } \\
\text { recruitment }\end{array}$ & Description \\
\hline $\begin{array}{l}\text { Japan Children's } \\
\text { Study }\end{array}$ & 2004 & $\begin{array}{l}465 \text { babies who were born in } \\
\text { three dispersed prefectures } \\
\text { (Mie, Tottori and Osaka) } \\
\text { between August } 2004 \text { and } \\
\text { April } 2006 \text {. }\end{array}$ & 4 month old & $\begin{array}{l}\text { Information } \\
\text { not identified }\end{array}$ & $\begin{array}{l}\text { This birth cohort study started with the aim of investigating } \\
\text { factors affecting children's physical and psycho-emotional } \\
\text { development. The baseline questionnaire was conducted when } \\
\text { children were } 4 \text { months old and follow-up surveys have been } \\
\text { administered regularly (Yamagata and JCS Group, 2009). Its } \\
\text { development outcome measures include "social competence" } \\
\text { which is measured by the Interaction Rating Scale (IRS) (Anme } \\
\text { et al., 2007). The IRS measures children's social competence } \\
\text { with the five subscales (1) autonomy, (2) responsiveness, ( } 3 \text { ) } \\
\text { empathy, (4) motor regulation, and (5) emotional self-regulation. } \\
\text { The evaluation is based on observation of a subject's interaction } \\
\text { with other people. A high correlation has been reported between } \\
\text { the IRS and the SDQ (Anme et al., 2010). }\end{array}$ \\
\hline $\begin{array}{l}\text { Japan Educational } \\
\text { Longitudinal Study } \\
\text { (JELS) }\end{array}$ & 2003 & $\begin{array}{l}1700 \text { to } 2700 \text { students for } \\
\text { each of the four cohorts } \\
\text { (elementary school third } \\
\text { graders and sixth graders, } \\
\text { junior high school third } \\
\text { graders and high school third } \\
\text { graders) from Kanto region } \\
\text { and Tohoku region }\end{array}$ & $\begin{array}{l}8-9,11-12 \\
14-15 \text { and } \\
17-18 \text { years } \\
\text { old }\end{array}$ & $\begin{array}{l}\text { Information } \\
\text { not identified }\end{array}$ & $\begin{array}{l}\text { This cohort study was launched with the aim of obtaining } \\
\text { statistical portraits of adolescents' academic abilities and general } \\
\text { competence, their aspirations and their life course. It conducts } \\
\text { surveys every three years administering academic assessment } \\
\text { of students, paper questionnaires for students, parents and } \\
\text { teachers and surveys on career choices for high school } \\
\text { graduates (Mimizuka, Wang and Tarumi, 2012). }\end{array}$ \\
\hline $\begin{array}{l}\text { Better Broadcasting } \\
\text { for Children Project }\end{array}$ & 2002 & $\begin{array}{l}\text { The initial main cohort was } \\
\text { composed of } 1368 \text { babies } \\
\text { born in Kawasaki city } \\
\text { between February and July } \\
2002 \text {. }\end{array}$ & Before birth & $\begin{array}{l}\text { Information } \\
\text { not identified }\end{array}$ & $\begin{array}{l}\text { This longitudinal cohort study was started by the NHK } \\
\text { Broadcasting Culture Research Institute, with the purpose of } \\
\text { exploring the relationship between determinants and outcomes } \\
\text { of children's media use. The project has conducted yearly } \\
\text { surveys and published several reports analysing the relationship } \\
\text { between children's media use and the family environment, } \\
\text { children's everyday life, parents' beliefs about children's media } \\
\text { use, parents' control of children's media use, parents' own media } \\
\text { use, children's mental/physical development and socio-economic } \\
\text { indicators such as parental occupation (NHK Broadcasting, } \\
\text { Culture Research Institute, 2010). }\end{array}$ \\
\hline $\begin{array}{l}\text { Better Environment } \\
\text { for Children Project }\end{array}$ & 2002 & $\begin{array}{l}643 \text { households with children } \\
\text { born in Kawasaki city } \\
\text { between October } 2002 \text { and } \\
\text { March } 2003\end{array}$ & Before birth & $\begin{array}{l}\text { Information } \\
\text { not identified }\end{array}$ & $\begin{array}{l}\text { The study aims at estimating environmental factors that are } \\
\text { related to children's maladjustment behaviours. It administers } \\
\text { annual questionnaire surveys to all participating households as } \\
\text { well as observational surveys to some of them (Sugawara, } \\
\text { 2010). }\end{array}$ \\
\hline
\end{tabular}


EDU/WKP(2015)10

\begin{tabular}{|c|c|c|c|c|c|}
\hline Survey & $\begin{array}{l}\text { Year } \\
\text { started }\end{array}$ & Sample at recruitment & $\begin{array}{l}\text { Age at } \\
\text { recruitment }\end{array}$ & $\begin{array}{l}\text { Response } \\
\text { rate at } \\
\text { recruitment }\end{array}$ & Description \\
\hline $\begin{array}{l}\text { Evaluation of Child } \\
\text { Night Care in } \\
\text { Nurseries }\end{array}$ & 1998 & $\begin{array}{l}3370 \text { children aged } 0 \text { to } 2 \\
\text { years and their parents }\end{array}$ & $0-2$ years & $\begin{array}{l}\text { Information } \\
\text { not identified }\end{array}$ & $\begin{array}{l}\text { This study started in order to investigate influence of extended } \\
\text { hours of nursery care on child development. Questionnaires } \\
\text { were administered after one, three and five years from the base } \\
\text { year to collect information on characteristics of nursery school } \\
\text { care, child-rearing environment, children's characteristics and } \\
\text { children's development (Anme and Oh, 2000). }\end{array}$ \\
\hline $\begin{array}{l}\text { Japan Child Care } \\
\text { Cohort Study }\end{array}$ & 1998 & $\begin{array}{l}1242 \text { infants in authorised } \\
\text { child-day-care centres } \\
\text { across Japan, their parents } \\
\text { and childcare professionals }\end{array}$ & 1 year & $71.5 \%$ & $\begin{array}{l}\text { The study seeks to investigate factors associated with child } \\
\text { development and quality of life. All governmentally authorised } \\
\text { child day-care and child night-care centres across Japan } \\
\text { participated in the study. Parents with a one-year-old child were } \\
\text { surveyed regarding their home environments and childcare } \\
\text { professionals evaluated the development of each child in the } \\
\text { facility. Follow-up surveys were administered every year (Anme } \\
\text { et al., 2012). }\end{array}$ \\
\hline $\begin{array}{l}\text { Keio longitudinal } \\
\text { twin study }\end{array}$ & 1998 & $\begin{array}{l}1040 \text { pairs of twins and } \\
\text { triplets living in Tokyo and } \\
\text { neighbouring cities, identified } \\
\text { through the use of official } \\
\text { residential records in the } \\
\text { Tokyo area }\end{array}$ & $\begin{array}{l}14 \text { to } 30 \\
\text { years old }\end{array}$ & $\begin{array}{l}17 \% \\
\text { (approx. } 1 \\
000 \text { pairs out } \\
\text { of } 6000 \text { ) }\end{array}$ & $\begin{array}{l}\text { This study was launched to conduct behavioural genetic studies } \\
\text { for various kinds of human psychological traits in adolescence } \\
\text { and young adulthood. The variables contain extensive human } \\
\text { behavioural and psychological traits including personality, } \\
\text { psychiatry, mental health, sociality, cognition, physical traits. } \\
\text { Environment of upbringing is measured from several angles } \\
\text { including retrospective parenting styles, family cohesion and } \\
\text { parent-offspring communication in childhood, assessed both by } \\
\text { each twin and by parents (Ando et al., 2006). }\end{array}$ \\
\hline Kawasaki Project & 1984 & $\begin{array}{l}1329 \text { pregnant women who } \\
\text { attended an antenatal clinic } \\
\text { in Kawasaki city between } \\
1984 \text { and } 1986 .\end{array}$ & Before birth & $\begin{array}{l}\text { Information } \\
\text { not identified }\end{array}$ & $\begin{array}{l}\text { This long-term longitudinal study was initially started to } \\
\text { investigate the relationship between children's behavioural } \\
\text { development and maternal characteristics. Children were } \\
\text { assessed when they were } 5 \text { days, } 1 \text { month, } 6 \text { months, } 18 \\
\text { months, } 5 \text { years, } 8 \text { years, } 10 \text { years } 14 \text { years and } 18 \text { years old } \\
\text { (Sugawara et al., 2006; Sugawara et al., 1999). }\end{array}$ \\
\hline
\end{tabular}


EDU/WKP(2015)10

\begin{tabular}{|l|l|l|l|l|l|}
\hline \multicolumn{1}{|c|}{ Survey } & $\begin{array}{c}\text { Year } \\
\text { started }\end{array}$ & \multicolumn{1}{|c|}{ Sample at recruitment } & $\begin{array}{c}\text { Age at } \\
\text { recruitment }\end{array}$ & $\begin{array}{c}\text { Response } \\
\text { rate at } \\
\text { recruitment }\end{array}$ & Description \\
\hline Osaka Report & 1980 & $\begin{array}{l}\text { All children (about 2 000) } \\
\text { born in a city in Osaka } \\
\text { Prefecture in 1980 }\end{array}$ & 4 months old & $83 \%$ & $\begin{array}{l}\text { This cohort study was started by paediatricians in order to study } \\
\text { the mental and physical development of children and its } \\
\text { relationship with the family environment. Questionnaires were } \\
\text { administered when the children were 4 months old, 7 months } \\
\text { old, 11 months old, 18 months old, 42 months old and six to } \\
\text { seven years old. Medical examinations were also conducted for } \\
\text { some years. The questionnaires included questions about } \\
\text { children's development, maternal health, parent-child } \\
\text { relationships and other environmental factors (Hattori and } \\
\text { Harada, 1991). A similar study was started in Hyogo Prefecture } \\
\text { in 2003 (Harada, 2006). }\end{array}$ \\
\hline
\end{tabular}




\section{ANNEX 4. PUBLISHED STUDIES IN JAPAN}

Strengthening parent-child relationship

\begin{tabular}{|c|c|c|c|c|c|}
\hline Authors & Context measures & Skills measures & Study population & Study design & Main findings \\
\hline $\begin{array}{l}\text { Hamano and } \\
\text { Uchida (2012) }\end{array}$ & $\begin{array}{l}\text { Parental discipline } \\
\text { style (sharing type, } \\
\text { authoritarian type, self- } \\
\text { sacrifice type) }\end{array}$ & $\begin{array}{l}\text { Pro-sociality and } \\
\text { maladjustment } \\
\text { tendencies measured } \\
\text { by the Strengths and } \\
\text { Difficulties } \\
\text { Questionnaire(SDQ) }\end{array}$ & $\begin{array}{l}2734 \text { preschool-age } \\
\text { children ( } 3 \text { to } 5 \text { years } \\
\text { old) and } 1780 \\
\text { caregivers }\end{array}$ & Cross-sectional design & $\begin{array}{l}\text { The sharing type discipline style was } \\
\text { strongly related with development of } \\
\text { pro-sociality. In addition, the sharing } \\
\text { type was negatively related with } \\
\text { maladjustment tendencies (conduct } \\
\text { problems, hyperactivity/inattention). } \\
\text { The authoritarian type was related } \\
\text { with both pro-sociality and } \\
\text { maladjustment tendencies, while the } \\
\text { relationships were weak. }\end{array}$ \\
\hline $\begin{array}{l}\text { Takahashi, } \\
\text { Roberts and } \\
\text { Hoshino (2012) }\end{array}$ & $\begin{array}{l}\text { Perceived parental } \\
\text { socialisation of } \\
\text { responsibility }\end{array}$ & $\begin{array}{l}\text { Conscientiousness } \\
\text { assessed by Japanese } \\
\text { version of NEO-Five } \\
\text { Factor Inventory }\end{array}$ & $\begin{array}{l}1485 \text { adults aged } 18 \\
\text { to } 70 \text { surveyed online }\end{array}$ & $\begin{array}{l}\text { Longitudinal design } \\
\text { using retrospective } \\
\text { surveys }\end{array}$ & $\begin{array}{l}\text { Perceived parental "socialisation of } \\
\text { responsibility" during adolescence is } \\
\text { related with conscientiousness in } \\
\text { adulthood. }\end{array}$ \\
\hline $\begin{array}{l}\text { Akimitsu and } \\
\text { Muramatsu } \\
\text { (2011) }\end{array}$ & $\begin{array}{l}\text { Paternal involvement in } \\
\text { parenting (assessed by } \\
\text { a } 42 \text {-item } \\
\text { questionnaire } \\
\text { answered separately } \\
\text { by fathers, mothers } \\
\text { and children), maternal } \\
\text { parenting attitudes }\end{array}$ & $\begin{array}{l}\text { Sociability assessed by } \\
\text { the social skills scales } \\
\text { for school }\end{array}$ & $\begin{array}{l}349 \text { students in the } \\
\text { fourth grade in a public } \\
\text { elementary school and } \\
\text { their parents }\end{array}$ & Cross-sectional design & $\begin{array}{l}\text { Direct effects on children's sociability } \\
\text { were found for the children's } \\
\text { perception of paternal involvement } \\
\text { with the children and for maternal } \\
\text { positive parenting attitude. It was } \\
\text { suggested that a father's perception } \\
\text { of his involvement with his child } \\
\text { indirectly influences development of } \\
\text { the child's sociability through the } \\
\text { child's perception and the mother's } \\
\text { parenting attitude. }\end{array}$ \\
\hline
\end{tabular}


EDU/WKP(2015)10

\begin{tabular}{|c|c|c|c|c|c|}
\hline Authors & Context measures & Skills measures & Study population & Study design & Main findings \\
\hline Tong et al. (2011) & $\begin{array}{l}\text { Parenting behaviours } \\
\text { assessed by a 13-item } \\
\text { scale }\end{array}$ & $\begin{array}{l}\text { Vocabulary } \\
\text { development, } \\
\text { communication } \\
\text { capabilities, evaluated } \\
\text { by childcare } \\
\text { professionals }\end{array}$ & $\begin{array}{l}398 \text { children who } \\
\text { entered child care } \\
\text { centres at the age one: } \\
\text { data were collected at } \\
\text { ages } 1 \text { and } 2 \text { (Child } \\
\text { Night Care in Nursery } \\
\text { project) }\end{array}$ & Longitudinal design & $\begin{array}{l}\text { Maternal practices of singing songs } \\
\text { with their children and playing with } \\
\text { them are beneficial to children's } \\
\text { vocabulary development one year } \\
\text { later. Conversely, punishing children } \\
\text { may exacerbate a vocabulary } \\
\text { developmental delay. Playing with } \\
\text { children is also related to their } \\
\text { communication competence and } \\
\text { maternal confidence about } \\
\text { childrearing is related to children's } \\
\text { communication development as well. }\end{array}$ \\
\hline $\begin{array}{l}\text { Shinohara et al. } \\
\text { (2011) }\end{array}$ & Maternal praise & $\begin{array}{l}\text { Social competence } \\
\text { measured by } \\
\text { Interaction Rating } \\
\text { Scale (IRS) }\end{array}$ & $\begin{array}{l}194 \text { mother-child } \\
\text { dyads: } \\
\text { Assessed when } \\
\text { children were 18, } 30 \\
\text { months (Japan } \\
\text { Children's Study) }\end{array}$ & Longitudinal design & $\begin{array}{l}\text { Mothers' actual praise-related } \\
\text { behaviours are related with the } \\
\text { trajectory of their children's social } \\
\text { competence from } 18 \text { months old to } 30 \\
\text { months old. }\end{array}$ \\
\hline $\begin{array}{l}\text { Uchida and Ishida } \\
\text { (2011) }\end{array}$ & $\begin{array}{l}\text { Parental discipline } \\
\text { style (sharing type, } \\
\text { authoritarian type, self- } \\
\text { sacrifice type) }\end{array}$ & $\begin{array}{l}\text { Japanese ability and } \\
\text { vocabulary measured } \\
\text { through individual } \\
\text { clinical interviews }\end{array}$ & $\begin{array}{l}2734 \text { preschool-age } \\
\text { children ( } 3 \text { to } 5 \text { years } \\
\text { old), follow-up tests } \\
\text { were administered } \\
\text { when the children were } \\
\text { in the first grade of } \\
\text { elementary school }\end{array}$ & $\begin{array}{l}\text { Cross-sectional design } \\
\text { and longitudinal design }\end{array}$ & $\begin{array}{l}\text { Preschool children's vocabulary score } \\
\text { has a positive association with the } \\
\text { "sharing type" discipline style and a } \\
\text { negative association with the } \\
\text { "authoritarian type" style, even after } \\
\text { controlling for maternal education and } \\
\text { household income. }\end{array}$ \\
\hline $\begin{array}{l}\text { Takeuchi et al. } \\
\text { (2011) }\end{array}$ & $\begin{array}{l}\text { Perceived parenting } \\
\text { styles (Care / } \\
\text { Overprotection) up to } \\
\text { the age of } 16 \\
\text { measured by the } \\
\text { Parental Bonding } \\
\text { Instrument (PBI) }\end{array}$ & $\begin{array}{l}\text { Temperament and } \\
\text { character dimensions } \\
\text { measured by the } \\
\text { Temperament and } \\
\text { Character Inventory } \\
\text { (TCI) }\end{array}$ & $\begin{array}{l}836 \text { university students } \\
(113 \text { men and } 787 \\
\text { women) who were } \\
\text { under } 26 \text { years old }\end{array}$ & $\begin{array}{l}\text { Retrospective } \\
\text { longitudinal design }\end{array}$ & $\begin{array}{l}\text { A path analysis shows that perceived } \\
\text { parenting (parental high care and low } \\
\text { overprotection) is associated with low } \\
\text { harm avoidance and high persistence } \\
\text { and is directly associated with high } \\
\text { self-directedness, high } \\
\text { cooperativeness and low self- } \\
\text { transcendence. }\end{array}$ \\
\hline
\end{tabular}


EDU/WKP(2015)10

\begin{tabular}{|c|c|c|c|c|c|}
\hline Authors & Context measures & Skills measures & Study population & Study design & Main findings \\
\hline $\begin{array}{l}\text { Fujiwara et al. } \\
\text { (2011) }\end{array}$ & $\begin{array}{l}\text { Maternal dysfunctional } \\
\text { parenting practices } \\
\text { (measured by } \\
\text { Parenting Scale, PS), } \\
\text { mental state } \\
\text { (Depression-Anxiety- } \\
\text { Stress Scale, DASS) } \\
\text { and self-evaluation of } \\
\text { parenting (Parenting } \\
\text { Experience Survey, } \\
\text { PES) }\end{array}$ & $\begin{array}{l}\text { Behavioural } \\
\text { problems (measured } \\
\text { by SDQ) }\end{array}$ & $\begin{array}{l}115 \text { mothers with 3- } \\
\text { year-old children in } \\
\text { Kawasaki City }\end{array}$ & $\begin{array}{l}\text { Quasi-experimental } \\
\text { design }\end{array}$ & $\begin{array}{l}\text { After a parenting support intervention } \\
\text { programme "Group Positive Parenting } \\
\text { Program" (Triple P), behavioural } \\
\text { problems of children in the } \\
\text { intervention group were reduced. In } \\
\text { addition, all subscales of the PS, the } \\
\text { DASS depression subscale and total } \\
\text { scores, as well as ratings for } \\
\text { perceived difficulty of parenting in the } \\
\text { PES, were significantly reduced in the } \\
\text { intervention group alone. }\end{array}$ \\
\hline $\begin{array}{l}\text { Cheng et al. } \\
(2010)\end{array}$ & $\begin{array}{l}\text { Maternal cognitive } \\
\text { stimulation }\end{array}$ & $\begin{array}{l}\text { Development } \\
\text { outcomes }\end{array}$ & $\begin{array}{l}284 \text { children, at age } 9 \\
\text { months and } 18 \text { months } \\
\text { (Japan Children's } \\
\text { Study) }\end{array}$ & Longitudinal design & $\begin{array}{l}\text { Maternal stimulation at } 9 \text { months old } \\
\text { was related to childhood development } \\
\text { at } 9 \text { months old and } 18 \text { months old. } \\
\text { Environmental stimulation did not } \\
\text { have significant relationship with } \\
\text { development at } 9 \text { months old and } 18 \\
\text { months old. }\end{array}$ \\
\hline $\begin{array}{l}\text { Shinohara et al. } \\
(2010)\end{array}$ & $\begin{array}{l}\text { Maternal attitude } \\
\text { towards praise }\end{array}$ & $\begin{array}{l}\text { Social competence } \\
\text { measured by } \\
\text { Interaction Rating } \\
\text { Scale (IRS) }\end{array}$ & $\begin{array}{l}176 \text { children with their } \\
\text { parents from two } \\
\text { Japanese cities. } \\
\text { Assessed when } \\
\text { children were } 4,9 \text { and } \\
18 \text { months old. (Japan } \\
\text { Children's Study) }\end{array}$ & Longitudinal design & $\begin{array}{l}\text { Continuous parental attitudes towards } \\
\text { the importance of "praise" at both } 4 \\
\text { and } 9 \text { months old are related to an } \\
\text { improved level of social competence } \\
\text { of the child at } 18 \text { months old, after } \\
\text { controlling for such factors as } \\
\text { children's gender, family type, } \\
\text { siblings, maternal and paternal age, } \\
\text { careers, educational level and family } \\
\text { income. }\end{array}$ \\
\hline $\begin{array}{l}\text { Tanaka et al. } \\
(2010)\end{array}$ & $\begin{array}{l}\text { Parenting behaviours } \\
\text { measured by the Index } \\
\text { of Child Care } \\
\text { Environment (ICCE) }\end{array}$ & $\begin{array}{l}\text { Responsiveness } \\
\text { measured by } \\
\text { Interaction Rating } \\
\text { Scale (IRS) }\end{array}$ & $\begin{array}{l}172 \text { children (18 } \\
\text { months old) and their } \\
\text { caregivers (Japan } \\
\text { Children's Study) }\end{array}$ & Cross-sectional design & $\begin{array}{l}\text { The responsiveness of children at } 18 \\
\text { months old correlated significantly } \\
\text { with "having a chance of reading } \\
\text { books to child" and "having spousal } \\
\text { support for child-rearing." }\end{array}$ \\
\hline
\end{tabular}


EDU/WKP(2015)10

\begin{tabular}{|c|c|c|c|c|c|}
\hline Authors & Context measures & Skills measures & Study population & Study design & Main findings \\
\hline $\begin{array}{l}\text { Hiramura et al. } \\
(2010)\end{array}$ & $\begin{array}{l}\text { Perceived parenting } \\
\text { styles (Care / } \\
\text { Overprotection) } \\
\text { measured by the } \\
\text { Parental Bonding } \\
\text { Instrument (PBI) }\end{array}$ & $\begin{array}{l}\text { Personality measured } \\
\text { by the Junior } \\
\text { Temperament and } \\
\text { Character Inventory } \\
\text { (JTCI), and } \\
\text { externalising problems } \\
\text { (aggression and } \\
\text { delinquency) reported } \\
\text { by parents measured } \\
\text { by the Child Behavior } \\
\text { Checklist (CBCL) }\end{array}$ & $\begin{array}{l}946 \text { children in the 5th } \\
\text { to 9th grades and their } \\
\text { parents }\end{array}$ & Cross-sectional design & $\begin{array}{l}\text { Both aggressive and delinquent } \\
\text { children were characterised by low } \\
\text { maternal care, high paternal over- } \\
\text { protection and low maternal } \\
\text { overprotection. Among personality } \\
\text { traits, novelty seeking was predicted } \\
\text { by low parental care and low paternal } \\
\text { and high maternal overprotection. }\end{array}$ \\
\hline $\begin{array}{l}\text { Cheng et al. } \\
(2009)\end{array}$ & $\begin{array}{l}\text { Cognitive stimulation } \\
\text { Supportive co- } \\
\text { parenting }\end{array}$ & $\begin{array}{l}\text { Development } \\
\text { outcomes }\end{array}$ & $\begin{array}{l}270 \text { children (Japan } \\
\text { Children's Study) }\end{array}$ & Longitudinal design & $\begin{array}{l}\text { Maternal cognitive stimulation at } 9 \\
\text { months old and supportive co- } \\
\text { parenting at } 4 \text { months old are related } \\
\text { to child development outcomes at } 9 \\
\text { months old. }\end{array}$ \\
\hline Aoki et al. (2007) & $\begin{array}{l}\text { Parental parenting } \\
\text { attitudes ("over } \\
\text { protectiveness" and } \\
\text { "over negative } \\
\text { parenting"), everyday } \\
\text { activities (pet breeding, } \\
\text { volunteering activities, } \\
\text { activities in nature) }\end{array}$ & $\begin{array}{l}\text { Social skills } \\
\text { (participation in group, } \\
\text { maintaining } \\
\text { relationships and } \\
\text { improving } \\
\text { relationships) }\end{array}$ & $\begin{array}{l}182 \text { elementary school } \\
\text { students (5th and 6th } \\
\text { graders) }\end{array}$ & Cross-sectional design & $\begin{array}{l}\text { Only for girls, paternal over protection } \\
\text { was positively associated with } \\
\text { behavioural tendency toward } \\
\text { improving relationships and maternal } \\
\text { negative parenting was negatively } \\
\text { associated with behavioural tendency } \\
\text { toward maintaining relationships. } \\
\text { There was no relationship found } \\
\text { between boys' social skills and } \\
\text { parenting attitudes. On the other } \\
\text { hand, everyday activities were related } \\
\text { with social skills of both boys and } \\
\text { girls. }\end{array}$ \\
\hline $\begin{array}{l}\text { Kanie et al. } \\
(2006)\end{array}$ & $\begin{array}{l}\text { Perceived family } \\
\text { atmosphere }\end{array}$ & Self-esteem & $\begin{array}{l}1118 \text { elementary } \\
\text { school third graders, } 1 \\
194 \text { elementary school } \\
\text { sixth graders and } 1 \\
057 \text { junior high school } \\
\text { third graders } \\
\text { (Japan Educational } \\
\text { Longitudinal Study } \\
2003 \text { ) }\end{array}$ & Cross-sectional design & $\begin{array}{l}\text { Perceived family atmosphere } \\
\text { positively correlated with children's } \\
\text { self-esteem. This perception of family } \\
\text { atmosphere was negatively related } \\
\text { with the parents' answer "telling the } \\
\text { child to study every day," and was } \\
\text { positively related with "helping the } \\
\text { child to study" and "taking the child to } \\
\text { museums". }\end{array}$ \\
\hline
\end{tabular}


EDU/WKP(2015)10

\begin{tabular}{|l|l|l|l|l|l|}
\hline \multicolumn{1}{|c|}{ Authors } & \multicolumn{1}{c|}{ Context measures } & Skills measures & \multicolumn{1}{c|}{ Study population } & \multicolumn{1}{c|}{ Study design } & \multicolumn{1}{c|}{ Main findings } \\
\hline $\begin{array}{l}\text { Togasaki and } \\
\text { Sakano (1997) }\end{array}$ & $\begin{array}{l}\text { Mother's attitudes for } \\
\text { child rearing }\end{array}$ & $\begin{array}{l}\text { Social skills at home, } \\
\text { social skills in school }\end{array}$ & $\begin{array}{l}524 \text { elementary school } \\
\text { children from 4th to 6th } \\
\text { grades }\end{array}$ & & $\begin{array}{l}\text { Cross-sectional design } \\
\text { Maternal attitude towards child } \\
\text { rearing is related with her child's } \\
\text { social skills at home and the social } \\
\text { skills at home are related with social } \\
\text { skills in school. }\end{array}$ \\
\hline
\end{tabular}


EDU/WKP(2015)10

Television viewing

\begin{tabular}{|c|c|c|c|c|c|}
\hline Authors & Context measures & Skills measures & Study population & Study design & Main findings \\
\hline Sugawara (2011) & $\begin{array}{l}\text { Television viewing time } \\
\text { at the ages } 0 \text { and } 6 \\
\text { years old }\end{array}$ & $\begin{array}{l}\text { Temperament at the } \\
\text { ages } 0 \text { and } 6 \text { years old, } \\
\text { measured by the } \\
\text { preschool version of } \\
\text { the Temperament and } \\
\text { Character Inventory }\end{array}$ & $\begin{array}{l}\text { Around } 1000 \text { children, } \\
\text { measured annually } \\
\text { from age } 0\end{array}$ & Longitudinal design & $\begin{array}{l}\text { Multiple regression analysis shows } \\
\text { that the television viewing time of } \\
\text { those children who have higher "harm } \\
\text { avoidance" of Cloninger's seven- } \\
\text { factor model is significantly longer. In } \\
\text { the meantime, cross-lagged effects } \\
\text { analysis shows that those children } \\
\text { who have the harm avoidance } \\
\text { tendency tend to watch television } \\
\text { longer, rather than the television } \\
\text { viewing time affecting children's harm } \\
\text { avoidance tendency. }\end{array}$ \\
\hline $\begin{array}{l}\text { Cheng et al. } \\
(2010)\end{array}$ & Television viewing time & $\begin{array}{l}\text { Behavioural and } \\
\text { emotional outcomes } \\
\text { measured by SDQ }\end{array}$ & $\begin{array}{l}316 \text { mother-child } \\
\text { dyads: assessed when } \\
\text { the child was } 9,18 \text { and } \\
30 \text { months old (Japan } \\
\text { Children's Study) }\end{array}$ & Longitudinal design & $\begin{array}{l}\text { TV exposure at } 18 \text { months old is } \\
\text { associated with hyper-activity } \\
\text { inattention and pro-social behaviour } \\
\text { at } 30 \text { months old. }\end{array}$ \\
\hline $\begin{array}{l}\text { Sumitani and } \\
\text { Muto (2010) }\end{array}$ & $\begin{array}{l}\text { Watching dramas, } \\
\text { comedy shows, talk } \\
\text { shows and music } \\
\text { programs on television }\end{array}$ & $\begin{array}{l}\text { Tendency to violate } \\
\text { rules and anxiety } \\
\text { tendency }\end{array}$ & $\begin{array}{l}1006 \text { elementary } \\
\text { school 5th graders } \\
\text { randomly chosen in the } \\
\text { Tokyo metropolitan } \\
\text { area. The survey was } \\
\text { administered annually } \\
\text { from February } 2001 \text { to } \\
\text { February } 2004 \text {. }\end{array}$ & Longitudinal design & $\begin{array}{l}\text { The results suggested that watching } \\
\text { dramas, comedy shows, talk shows } \\
\text { and music programmes on television } \\
\text { may heighten the social and } \\
\text { psychological maladjustment of } \\
\text { adolescents. In particular, it was } \\
\text { indicated that watching these } \\
\text { programmes during fifth and sixth } \\
\text { grades might heighten the tendency } \\
\text { to violate rules and the anxiety } \\
\text { tendency during first and second } \\
\text { grades in junior high school. }\end{array}$ \\
\hline $\begin{array}{l}\text { Kano et al. } \\
(2007)\end{array}$ & Television viewing time & Social development & $\begin{array}{l}1180 \text { children } 36 \\
\text { months of age }\end{array}$ & Cross-sectional design & $\begin{array}{l}\text { Long exposure to TV was related to } \\
\text { slower social development. }\end{array}$ \\
\hline
\end{tabular}


EDU/WKP(2015)10

\begin{tabular}{|c|c|c|c|c|c|}
\hline Authors & t measures & & Stud & & \\
\hline Sugawara (2005) & $\begin{array}{l}\text { Media contact time in } \\
\text { one week at age } 0 \text { and } \\
\text { at age } 1\end{array}$ & $\begin{array}{l}\text { Verbal and non-verbal } \\
\text { communication } \\
\text { behaviours (assessed } \\
\text { by MacArthur } \\
\text { Communicative } \\
\text { Development } \\
\text { Inventories) and overall } \\
\text { development } \\
\text { (assessed by PDQ of } \\
\text { DDST) at age } 1\end{array}$ & $\begin{array}{l}1150 \text { children (Better } \\
\text { Broadcasting for } \\
\text { Children Project) }\end{array}$ & Longitudinal design & $\begin{array}{l}\text { Long exposure to TV is related to } \\
\text { lower scores in the communicative } \\
\text { development test. However, this } \\
\text { relationship becomes less significant } \\
\text { when the time spent playing outside } \\
\text { and the frequency of reading books } \\
\text { are controlled. Media exposure has } \\
\text { little relationship with general } \\
\text { development. }\end{array}$ \\
\hline $\begin{array}{l}\text { Sugawara et al. } \\
(2005)\end{array}$ & $\begin{array}{l}\text { Television viewing time } \\
\text { when child is } 0 \text { to } 2 \\
\text { years old }\end{array}$ & $\begin{array}{l}\text { Communicative } \\
\text { development }\end{array}$ & 1023 children, age 0 & Longitudinal design & $\begin{array}{l}\text { Long exposure to TV is related to } \\
\text { lower scores in the communicative } \\
\text { development test. }\end{array}$ \\
\hline $\begin{array}{l}\text { Omi and } \\
\text { Sakamoto (2005) }\end{array}$ & Television viewing time & $\begin{array}{l}\text { Cognitive test scores; } \\
\text { practical skills to use } \\
\text { information, } \\
\text { aggressiveness, pro- } \\
\text { sociality (self-report, } \\
\text { only for elementary } \\
\text { school 5th graders and } \\
\text { junior high school 2nd } \\
\text { graders) }\end{array}$ & $\begin{array}{l}98 \text { elementary school } \\
\text { 2nd graders, } 91 \\
\text { elementary school } 5 \text { th } \\
\text { graders, } 59 \text { junior high } \\
\text { school } 2 \text { nd graders } \\
\text { who responded to } \\
\text { surveys in both } 2003 \\
\text { and } 2004\end{array}$ & Longitudinal design & $\begin{array}{l}\text { No effect of television viewing time on } \\
\text { cognitive ability was found. For } \\
\text { elementary school 5th graders, those } \\
\text { who were exposed to television } \\
\text { longer at the first time point tended to } \\
\text { have lower aggressiveness at the } \\
\text { second time point. }\end{array}$ \\
\hline $\begin{array}{l}\text { Shibuya et al. } \\
(2004)\end{array}$ & $\begin{array}{l}\text { Media (television and } \\
\text { video games) contact } \\
\text { time, frequency of } \\
\text { watching violent } \\
\text { scenes in media }\end{array}$ & $\begin{array}{l}\text { The empathy scale for } \\
\text { children, the Social } \\
\text { Desirability Scale for } \\
\text { Children, HAQ-C } \\
\text { (verbal aggression, } \\
\text { physical aggression, } \\
\text { anger, hostility), } \\
\text { aggressive behaviours } \\
\text { in the past month and } \\
\text { pro-social behaviours }\end{array}$ & $\begin{array}{l}597 \text { elementary school } \\
5 \text { th graders in } 6 \\
\text { schools randomly } \\
\text { selected from all the } \\
\text { large-scale schools in } \\
\text { Japan }\end{array}$ & $\begin{array}{l}\text { Longitudinal design } \\
\text { Two waves with a one- } \\
\text { month interval }\end{array}$ & $\begin{array}{l}\text { Results suggest that long exposure to } \\
\text { television may enhance physical } \\
\text { aggression, anger and aggressive } \\
\text { behaviours. Similarly, time spent } \\
\text { playing video games was also related } \\
\text { to physical aggression and anger. } \\
\text { The frequency of watching violent } \\
\text { scenes was related to anger, for both } \\
\text { television and video games, but } \\
\text { particularly for video games. }\end{array}$ \\
\hline
\end{tabular}


EDU/WKP(2015)10

Family socio-economic backgrounds

\begin{tabular}{|c|c|c|c|c|c|}
\hline Authors & Context measures & Skills measures & Study population & Study design & Main findings \\
\hline $\begin{array}{l}\text { Shikishima, } \\
\text { Yamashita and } \\
\text { Akabayashi } \\
(2012)\end{array}$ & $\begin{array}{l}\text { Parental report on } \\
\text { household annual } \\
\text { income, parental } \\
\text { educational attainment, } \\
\text { parental employment }\end{array}$ & $\begin{array}{l}\text { Social skills measured } \\
\text { by SDQ, Quality of Life } \\
\text { measured by KINDL }{ }^{\circledR}\end{array}$ & $\begin{array}{l}660 \text { parents with } \\
\text { children in elementary } \\
\text { school and junior high } \\
\text { school and the children } \\
\text { (Japan Child Panel } \\
\text { Survey 2011) }\end{array}$ & Cross-sectional design & $\begin{array}{l}\text { Household income had significant } \\
\text { negative relationships with children's } \\
\text { social skills in terms of the emotional } \\
\text { symptoms subscale and the peer } \\
\text { relationship problems subscale. } \\
\text { Household income had significant } \\
\text { positive relationships with most } \\
\text { subscales of the child's quality of life } \\
\text { (except the family subscale with } \\
\text { which the relationship is negative), } \\
\text { even after parents' educational } \\
\text { attainment, employment and age } \\
\text { were controlled. }\end{array}$ \\
\hline
\end{tabular}


Maternal mental health

\begin{tabular}{|c|c|c|c|c|c|}
\hline Authors & Context measures & Skills measures & Study population & Study design & Main findings \\
\hline $\begin{array}{l}\text { Shikishima, } \\
\text { Yamashita and } \\
\text { Akabayashi } \\
(2012)\end{array}$ & Parental mental health & $\begin{array}{l}\text { Social skills (measured } \\
\text { by SDQ), quality of life } \\
\text { (measured by } \\
\text { KINDL } ® \text { ) }\end{array}$ & $\begin{array}{l}660 \text { parents with } \\
\text { children (elementary } \\
\text { school and junior high } \\
\text { school) and their } \\
\text { children (Japan Child } \\
\text { Panel Survey 2011) }\end{array}$ & Cross-sectional design & $\begin{array}{l}\text { Maternal mental health has a } \\
\text { statistically significant relationship } \\
\text { with most subscales of children's } \\
\text { social skills (emotional symptoms, } \\
\text { conduct problems, } \\
\text { hyperactivity/inattention, peer } \\
\text { relationship problems, total } \\
\text { difficulties). Paternal mental health } \\
\text { has a relationship with only } \\
\text { hyperactivity/inattention. Parental } \\
\text { mental health has little relationship } \\
\text { with quality of life scores. }\end{array}$ \\
\hline Ishii et al. (2011) & $\begin{array}{l}\text { Types of maternal } \\
\text { stress, parenting } \\
\text { attitudes and support, } \\
\text { child care use }\end{array}$ & $\begin{array}{l}\text { Social development } \\
\text { (life skills and } \\
\text { interpersonal skills), } \\
\text { language development } \\
\text { (communication skills } \\
\text { and understanding), } \\
\text { motor development } \\
\text { (fine and gross motor } \\
\text { skills) assessed by } \\
\text { childcare professionals }\end{array}$ & $\begin{array}{l}370 \text { five-year-olds in } \\
\text { child care centres } \\
\text { (Evaluation of Child } \\
\text { Night Care in Nursery } \\
\text { project) }\end{array}$ & Cross-sectional design & $\begin{array}{l}\text { Stress of mothers immediately after } \\
\text { birth was significantly related to } \\
\text { punishing the child and also the } \\
\text { child's risk of maladjustment at child } \\
\text { care. Maternal stress at the time of } \\
\text { the survey was significantly related to } \\
\text { the lack of interaction with the child, } \\
\text { such as reading books, shopping and } \\
\text { playing and also with the child's } \\
\text { maladjustment at childcare centres. }\end{array}$ \\
\hline $\begin{array}{l}\text { Cheng et al. } \\
(2007)\end{array}$ & $\begin{array}{l}\text { Mother-child } \\
\text { relationship }\end{array}$ & $\begin{array}{l}\text { Behavioural problems } \\
\text { assessed by the Child } \\
\text { Behavior Checklist } \\
(\mathrm{CBCL})\end{array}$ & $\begin{array}{l}85 \text { mother-child dyads, } \\
\text { at age } 4 \text { months and } \\
10 \text { months }\end{array}$ & Longitudinal design & $\begin{array}{l}\text { Disturbed mother-infant relationships } \\
\text { at } 10 \text { months old and maternal } \\
\text { depression at } 4 \text { months old } \\
\text { significantly increased the risk of high } \\
\text { scores on the Child Behavior } \\
\text { Checklist. }\end{array}$ \\
\hline $\begin{array}{l}\text { Sugawara et al. } \\
(2006)\end{array}$ & $\begin{array}{l}\text { Maternal life } \\
\text { dissatisfaction }\end{array}$ & $\begin{array}{l}\text { Behavioural problems } \\
\text { at age 10: externalising } \\
\text { problems measured by } \\
\text { the Child Behavior } \\
\text { Checklist (CBCL) }\end{array}$ & $\begin{array}{l}269 \text { mother-child dyads } \\
\text { (Kawasaki project) }\end{array}$ & Cross-sectional design & $\begin{array}{l}\text { Multiple regression analysis shows } \\
\text { that maternal life dissatisfaction is } \\
\text { significantly associated with children's } \\
\text { externalising problems. }\end{array}$ \\
\hline
\end{tabular}


EDU/WKP(2015)10

\begin{tabular}{|c|c|c|c|c|c|}
\hline Authors & Context measures & Skills measures & Study population & Study design & Main findings \\
\hline $\begin{array}{l}\text { Kikawada et al. } \\
\text { (2006) }\end{array}$ & $\begin{array}{l}\text { Maternal stress during } \\
\text { pregnancy, after birth } \\
\text { and at the time of the } \\
\text { survey }\end{array}$ & $\begin{array}{l}\text { Development (social } \\
\text { development, language } \\
\text { development and } \\
\text { motor development), } \\
\text { social adaptation and } \\
\text { problem behaviours } \\
\text { assessed by mothers } \\
\text { childcare professionals }\end{array}$ & $\begin{array}{l}419 \text { four-year-old } \\
\text { children }\end{array}$ & Cross-sectional design & $\begin{array}{l}\text { Children of mothers who were highly } \\
\text { stressed after birth are more likely to } \\
\text { be in a risk group in terms of gross } \\
\text { motor development and adaptation to } \\
\text { nursery cares compared to children } \\
\text { whose mothers were not highly } \\
\text { stressed. However, there is no } \\
\text { difference between the two groups in } \\
\text { other developmental arenas and } \\
\text { problem behaviours. Mothers who } \\
\text { were highly stressed during } \\
\text { pregnancy and at the time of the } \\
\text { survey do not differ from mothers who } \\
\text { were not highly stressed in children's } \\
\text { developmental outcomes. }\end{array}$ \\
\hline $\begin{array}{l}\text { Sugawara et al. } \\
\text { (1999) }\end{array}$ & Maternal depression & $\begin{array}{l}\text { Temperament } \\
\text { measured by the } \\
\text { Revised Infant } \\
\text { Temperament } \\
\text { Questionnaire (RITQ) } \\
\text { at age } 6 \text { months and } \\
\text { the Toddler } \\
\text { Temperament Scale } \\
\text { (TTS) at age } 18 \\
\text { months }\end{array}$ & $\begin{array}{l}1329 \text { women who } \\
\text { attended an antenatal } \\
\text { clinic: their children } \\
\text { were assessed at the } \\
\text { ages of } 6 \text { and } 18 \\
\text { months, while mothers } \\
\text { were assessed when } \\
\text { children were } 5 \text { days } \\
\text { and } 12 \text { months old } \\
\text { (Kawasaki project) }\end{array}$ & Longitudinal design & $\begin{array}{l}\text { Maternal depression in the early } \\
\text { postpartum period may affect child } \\
\text { early temperament. Of the five } \\
\text { temperamental dimensions of the } \\
\text { Japanese versions of the RITQ and } \\
\text { TTS, "rhythmicity" and "attention span } \\
\text { and persistence" showed reciprocal } \\
\text { relationships with postnatal } \\
\text { depression. Early maternal } \\
\text { depression ( } 5 \text { days after delivery) } \\
\text { correlated negatively with "frustration } \\
\text { tolerance" in early infancy ( } 6 \text { months } \\
\text { old) and late maternal depression (12 } \\
\text { months old) was related positively to } \\
\text { "fear of strangers and strange } \\
\text { situations" in late infancy (18 months } \\
\text { old). }\end{array}$ \\
\hline
\end{tabular}


Maternal employment

\begin{tabular}{|c|c|c|c|c|c|}
\hline Authors & Context measures & Skills measures & Study population & Study design & Main findings \\
\hline Nozaki (2013) & $\begin{array}{l}\text { Maternal employment } \\
\text { when the child was } \\
\text { between } 0 \text { and } 3 \text { years } \\
\text { old }\end{array}$ & $\begin{array}{l}\text { Academic achievement } \\
\text { test scores, behaviour } \\
\text { problems and pro- } \\
\text { sociality rated by } \\
\text { parents (measured by } \\
\text { SDQ), children's } \\
\text { quality of life } \\
\text { (measured by } \\
\text { KINDL } ® \text { ) }\end{array}$ & $\begin{array}{l}1044 \text { children } \\
\text { (elementary school and } \\
\text { junior high school) from } \\
\text { the Japan Child Panel } \\
\text { Survey } 2011 \text { and } 2012\end{array}$ & $\begin{array}{l}\text { Longitudinal design } \\
\text { using retrospective } \\
\text { surveys }\end{array}$ & $\begin{array}{l}\text { There was a significant negative } \\
\text { correlation between maternal } \\
\text { employment during the child's infancy } \\
\text { and the child's academic } \\
\text { achievement. However, this negative } \\
\text { correlation diminishes as the grade } \\
\text { levels advance and disappears at the } \\
\text { junior high school level. Maternal } \\
\text { employment during the child's infancy } \\
\text { had no correlation with the child's } \\
\text { behaviour problems, pro-sociality and } \\
\text { quality of life. }\end{array}$ \\
\hline Kan (2012) & $\begin{array}{l}\text { Maternal employment } \\
\text { when the child was in } \\
\text { junior high school }\end{array}$ & $\begin{array}{l}\text { Behavioural problems, } \\
\text { academic achievement }\end{array}$ & $\begin{array}{l}23-40 \text { years recalling } \\
\text { their adolescence } \\
\text { (Japanese Life Course } \\
\text { Panel Survey: JLPS } \\
\text { Waves } 1 \text { and } 2 \text { ) }\end{array}$ & $\begin{array}{l}\text { Longitudinal design } \\
\text { using retrospective } \\
\text { surveys }\end{array}$ & $\begin{array}{l}\text { Maternal full-time employment may } \\
\text { prevent sons from smoking at school. } \\
\text { Effects of maternal employment on } \\
\text { children's educational attainment } \\
\text { were not observed after controlling for } \\
\text { family and school characteristics. }\end{array}$ \\
\hline $\begin{array}{l}\text { Ueno, Miyake and } \\
\text { Katsurada (2009) }\end{array}$ & $\begin{array}{l}\text { Maternal motivation to } \\
\text { work, maternal job } \\
\text { satisfaction, maternal } \\
\text { childrearing style }\end{array}$ & $\begin{array}{l}\text { Social skills: assessed } \\
\text { by care professionals } \\
\text { using "Child Social } \\
\text { Development Test" by } \\
\text { Toshobunka ( } 5 \text { sub } \\
\text { scales including } \\
\text { independence, } \\
\text { altruism, cooperation, } \\
\text { responsibility and } \\
\text { perseverance) }\end{array}$ & $\begin{array}{l}56 \text { nursery day care } \\
\text { students with working } \\
\text { mothers }\end{array}$ & Cross-sectional design & $\begin{array}{l}\text { When children are grouped based on } \\
\text { their mothers' motivation to work: 1) } \\
\text { because of financial reasons and 2) } \\
\text { because of maternal interest in } \\
\text { working, the children of the mothers } \\
\text { who selected 2) had statistically } \\
\text { significantly higher scores in altruism } \\
\text { and cooperation. There is significant } \\
\text { correlation between mothers' job } \\
\text { satisfactions and children's } \\
\text { independence, altruism and } \\
\text { perseverance. No significant } \\
\text { correlation is found between mothers' } \\
\text { childrearing styles and children's } \\
\text { social skills. }\end{array}$ \\
\hline
\end{tabular}


EDU/WKP(2015)10

\begin{tabular}{|c|c|c|c|c|c|}
\hline Authors & Context measures & Skills measures & Study population & Study design & Main findings \\
\hline $\begin{array}{l}\text { Sugawara et al. } \\
(2006)\end{array}$ & $\begin{array}{l}\text { Maternal employment } \\
\text { before age } 3\end{array}$ & $\begin{array}{l}\text { Behavioural problems } \\
\text { (externalising } \\
\text { problems): } \\
\text { - Emergence of } \\
\text { Externalising Problem } \\
\text { Behavior Checklist } \\
\text { (EEPBCL) at the ages } \\
\text { of } 6 \text { months, } 18 \\
\text { months, } 5 \text { years } \\
\text { - Child Behaviour } \\
\text { Checklist (CBCL) at } 8 \\
\text { and } 10 \text { years of age }\end{array}$ & $\begin{array}{l}1260 \text { mother-child } \\
\text { dyads: Children were } \\
\text { assessed at the ages } \\
\text { of } 6 \text { months, } 18 \\
\text { months, } 5 \text { years, } 8 \\
\text { years and } 10 \text { years } \\
\text { (Kawasaki project) }\end{array}$ & Longitudinal design & $\begin{array}{l}\text { No relationship between maternal } \\
\text { employment before age } 3 \text { years and } \\
\text { children's behavioural problems was } \\
\text { found. Children whose mothers had } \\
\text { returned to work before they reached } \\
\text { age } 3 \text { years reported significantly } \\
\text { fewer externalising problems when } \\
\text { they were } 18 \text { months and } 5 \text { years old. } \\
\text { For ages } 0 \text { through } 8 \text {, significantly } \\
\text { fewer behavioural problems were } \\
\text { reported for children with mothers } \\
\text { who continued to work full-time after } \\
\text { the child's birth without changing jobs } \\
\text { due to childbirth, compared to } \\
\text { children with mothers who resigned } \\
\text { from work for pregnancy or } \\
\text { childrearing and subsequently re- } \\
\text { entered the workforce. }\end{array}$ \\
\hline $\begin{array}{l}\text { Hattori and } \\
\text { Harada (1991) }\end{array}$ & Maternal employment & $\begin{array}{l}\text { Cognitive and psycho- } \\
\text { emotional development }\end{array}$ & $\begin{array}{l}\text { All children born in } \\
1980 \text { in a city in Osaka: } \\
\text { about } 2000 \text { new-borns } \\
\text { (Osaka report): } \\
\text { assessed at the ages } \\
\text { of } 4 \text { months, } 7 \text { months, } \\
11 \text { months, } 18 \text { months, } \\
42 \text { months and } 6 \text { to } 7 \\
\text { years }\end{array}$ & $\begin{array}{l}\text { Longitudinal design } \\
\text { Chi-square test }\end{array}$ & $\begin{array}{l}\text { There is no correlation found between } \\
\text { maternal employment and the child's } \\
\text { physical, cognitive and psycho- } \\
\text { emotional development. }\end{array}$ \\
\hline
\end{tabular}




\section{Classroom instruction}

\begin{tabular}{|c|c|c|c|c|c|}
\hline Authors & Context measures & Skills measures & Study population & Study design & Main findings \\
\hline Harada (2014) & $\begin{array}{l}\text { Social skills training (5 } \\
\text { sessions, } 2 \text { months) }\end{array}$ & $\begin{array}{l}\text { Social Skills Scale } \\
\text { (relationship initiation, } \\
\text { decoding, self- } \\
\text { assertiveness, } \\
\text { emotional control, } \\
\text { relationship } \\
\text { maintenance and } \\
\text { encoding), Self-Esteem } \\
\text { Survey and Empathic- } \\
\text { Affective Scale }\end{array}$ & $\begin{array}{l}320 \text { high school 1st } \\
\text { graders }\end{array}$ & $\begin{array}{l}\text { Quasi-experimental } \\
\text { design (without control } \\
\text { group) }\end{array}$ & $\begin{array}{l}\text { Among skills measured, decoding, } \\
\text { self-assertiveness and emotional } \\
\text { control of social skills increased } \\
\text { statistically significantly after the } \\
\text { training. }\end{array}$ \\
\hline $\begin{array}{l}\text { Horikawa and } \\
\text { Shibayama } \\
\text { (2014) }\end{array}$ & $\begin{array}{l}\text { A psychological } \\
\text { education programme } \\
\text { based on the theory of } \\
\text { cognitive behavioral } \\
\text { therapy ( } 6 \text { sessions, } 1 \\
\text { hour each) }\end{array}$ & Anxiety, self-esteem & $\begin{array}{l}27 \text { elementary school } \\
4 \text { th graders }\end{array}$ & $\begin{array}{l}\text { Quasi-experimental } \\
\text { design (without control } \\
\text { group) }\end{array}$ & $\begin{array}{l}\text { The programme was found to be } \\
\text { effective in improving self-esteem and } \\
\text { reducing anxiety generally, and the } \\
\text { effect was maintained one and a half } \\
\text { months later. The programme was } \\
\text { particularly effective for those who } \\
\text { had lower self-esteem or higher } \\
\text { anxiety. }\end{array}$ \\
\hline $\begin{array}{l}\text { Ikejima and Fukui } \\
(2012)\end{array}$ & $\begin{array}{l}\text { Pair learning with a } \\
\text { peer support } \\
\text { programme during } \\
\text { English lessons }\end{array}$ & $\begin{array}{l}\text { Interpersonal } \\
\text { adjustment ("friends' } \\
\text { support," "pro-social } \\
\text { skills" and "anti-bullying } \\
\text { relationship") } \\
\text { measured by the } \\
\text { Adaptation Scale for } \\
\text { School Environments } \\
\text { on Six Spheres } \\
\text { (ASSESS) }\end{array}$ & $\begin{array}{l}35 \text { junior high school } \\
\text { 2nd graders }\end{array}$ & $\begin{array}{l}\text { 準実験的デザイン } \\
\text { (統制群なし) }\end{array}$ & $\begin{array}{l}\text { After the pair learning, the relationship } \\
\text { among the students and their pro- } \\
\text { social skills improved. However, there } \\
\text { was a decline in "anti-bullying } \\
\text { relationship" scores, which indicates } \\
\text { potential effects of a large gap in } \\
\text { academic skill levels between paired } \\
\text { students. }\end{array}$ \\
\hline
\end{tabular}


EDU/WKP(2015)10

\begin{tabular}{|c|c|c|c|c|c|}
\hline Authors & Context measures & Skills measures & Study population & Study design & Main findings \\
\hline Ando (2010) & $\begin{array}{l}2 \text { types of psycho- } \\
\text { educational } \\
\text { programme } \\
\text { "Successful Self 2" }\end{array}$ & $\begin{array}{l}\text { Problem behaviours } \\
\text { including bullying, self- } \\
\text { control, the number of } \\
\text { friends engaging in } \\
\text { problem behaviours, } \\
\text { self-efficacy to reject } \\
\text { friends' temptation for } \\
\text { problem behaviours, } \\
\text { sociality, mood states } \\
\text { (Profile of Mood States } \\
\text { (POMS) Brief) }\end{array}$ & $\begin{array}{l}143 \text { junior high school } \\
\text { 2nd graders }\end{array}$ & $\begin{array}{l}\text { Quasi-experimental } \\
\text { design (without control } \\
\text { group) }\end{array}$ & $\begin{array}{l}\text { For both of the groups, "bullying," and } \\
\text { "the number of bully friends," } \\
\text { decreased and "serious attitudes } \\
\text { towards school life," "smooth } \\
\text { relationships with friends," "Vigor- } \\
\text { Activity" increased after the } \\
\text { intervention. For one group, "sociality" } \\
\text { and "mood states" also increased. }\end{array}$ \\
\hline Makino (2011) & $\begin{array}{l}\text { Communication } \\
\text { training programme }\end{array}$ & $\begin{array}{l}\text { Communication skills, } \\
\text { self-concept (self- } \\
\text { esteem, self-efficacy) }\end{array}$ & $\begin{array}{l}6 \text { junior high school } \\
\text { students }\end{array}$ & $\begin{array}{l}\text { Quasi-experimental } \\
\text { design (without control } \\
\text { group) }\end{array}$ & $\begin{array}{l}\text { After the training, some stimulatory } \\
\text { effects were observed on the } \\
\text { participants' communication skills. } \\
\text { However, there was no change in } \\
\text { their self-esteem and self-efficacy. }\end{array}$ \\
\hline $\begin{array}{l}\text { Komatsu and } \\
\text { Hida (2009) }\end{array}$ & $\begin{array}{l}2 \text { types of group } \\
\text { experience exercises, } \\
\text { evaluation of } \\
\text { classroom environment } \\
\text { (supportive } \\
\text { atmosphere, } \\
\text { affirmative group } \\
\text { environment, } \\
\text { disciplinary } \\
\text { environment, disturbing } \\
\text { atmosphere) }\end{array}$ & $\begin{array}{l}\text { Self-consciousness } \\
\text { (self-affirmation, } \\
\text { academic motivation, } \\
\text { self-denial, social } \\
\text { consideration, social } \\
\text { alienation), self-rated } \\
\text { social skills (basic skills } \\
\text { for group participation, } \\
\text { active relationship } \\
\text { building skills, self- } \\
\text { assertiveness) }\end{array}$ & $\begin{array}{l}85 \text { elementary school } \\
4 \text { th graders }\end{array}$ & $\begin{array}{l}\text { Quasi-experimental } \\
\text { design }\end{array}$ & $\begin{array}{l}\text { There was no difference between the } \\
\text { experiment group and control group in } \\
\text { the change in self-consciousness. In } \\
\text { the group who participated in exercise } \\
\text { I, evaluation for classroom improved } \\
\text { as well as self-evaluation of social } \\
\text { skills. On the other hand, in the group } \\
\text { who participated in exercise Il and the } \\
\text { control group, there was no significant } \\
\text { improvement in evaluation of the } \\
\text { classroom environment or self- } \\
\text { evaluation of social skills. Those } \\
\text { students whose "supportive } \\
\text { atmosphere" of evaluation of } \\
\text { classroom environment improved } \\
\text { tended to have improved "basic skills } \\
\text { for group participation" and "active } \\
\text { relationship building skills" among } \\
\text { self-rated social skills. }\end{array}$ \\
\hline
\end{tabular}


EDU/WKP(2015)10

\begin{tabular}{|c|c|c|c|c|c|}
\hline Authors & Context measures & Skills measures & Study population & Study design & Main findings \\
\hline Ando (2008) & $\begin{array}{l}\text { Psycho-educational } \\
\text { programme } \\
\text { "Successful Self" }\end{array}$ & $\begin{array}{l}\text { Emotional and } \\
\text { behavioural problems, } \\
\text { bullying and being } \\
\text { bullied, adjustment to } \\
\text { school society, } \\
\text { influence from friends } \\
\text { engaging in problem } \\
\text { behaviours, impulsivity/ } \\
\text { aggressiveness, self- } \\
\text { efficacy to reject } \\
\text { friends' temptation for } \\
\text { problem behaviours }\end{array}$ & $\begin{array}{l}51 \text { elementary school } \\
\text { 4th graders }\end{array}$ & $\begin{array}{l}\text { Quasi-experimental } \\
\text { design (without control } \\
\text { group) }\end{array}$ & $\begin{array}{l}\text { For both boys and girls, there were } \\
\text { significant declines in } \\
\text { "impulsivity/aggressiveness," } \\
\text { "bullying," "physical bullying," "verbal } \\
\text { bullying," "isolating someone," "being } \\
\text { physically bullied," "being neglected," } \\
\text { "being isolated," "going out at night," } \\
\text { "depression," "crying, feeling like } \\
\text { crying," "insomnia." }\end{array}$ \\
\hline $\begin{array}{l}\text { Watanabe and } \\
\text { Harada (2007) }\end{array}$ & Social skill training & $\begin{array}{l}\text { Social skills, self- } \\
\text { esteem }\end{array}$ & $\begin{array}{l}29 \text { high school 3rd } \\
\text { graders }\end{array}$ & $\begin{array}{l}\text { Quasi-experimental } \\
\text { design }\end{array}$ & $\begin{array}{l}\text { After the training, there was an } \\
\text { increase in social skills of the } \\
\text { treatment group. As for self-esteem, } \\
\text { there were declines in average scores } \\
\text { of both the treatment and control } \\
\text { groups, but the decline for the } \\
\text { treatment group was moderate } \\
\text { compared to that for the control } \\
\text { group. }\end{array}$ \\
\hline $\begin{array}{l}\text { Kawai et al. } \\
(2006)\end{array}$ & $\begin{array}{l}\text { A classroom-based } \\
\text { training programme } \\
\text { that encourages } \\
\text { students to argue } \\
\text { against someone } \\
\text { else's self-defeating } \\
\text { cognitions }\end{array}$ & $\begin{array}{l}\text { Self-efficacy, self- } \\
\text { esteem }\end{array}$ & $\begin{array}{l}120 \text { elementary school } \\
5 \text { th and } 6 \text { th graders }\end{array}$ & $\begin{array}{l}\text { Quasi-experimental } \\
\text { design }\end{array}$ & $\begin{array}{l}\text { The results indicated that, in } \\
\text { comparison to the control group, the } \\
\text { children in the experimental group } \\
\text { showed a stronger general attitude of } \\
\text { denying self-defeating cognition } \\
\text { patterns, and had higher self-efficacy } \\
\text { and self-esteem. }\end{array}$ \\
\hline $\begin{array}{l}\text { Ikejima et al. } \\
\text { (2004) }\end{array}$ & $\begin{array}{l}\text { Peer support } \\
\text { programme } \\
\text { implemented during } \\
\text { Japanese lessons }\end{array}$ & $\begin{array}{l}\text { Social skills } \\
\text { ("consideration skill" } \\
\text { and "relation skill") }\end{array}$ & $\begin{array}{l}32 \text { elementary school } \\
5 \text { th graders }\end{array}$ & $\begin{array}{l}\text { Quasi-experimental } \\
\text { design (without control } \\
\text { group) }\end{array}$ & $\begin{array}{l}\text { A significant increase was observed } \\
\text { in both "consideration skill" and } \\
\text { "relation skill" after the implementation } \\
\text { of programme. }\end{array}$ \\
\hline
\end{tabular}


EDU/WKP(2015)10

\begin{tabular}{|c|c|c|c|c|c|}
\hline Authors & Context measures & Skills measures & Study population & Study design & Main findings \\
\hline $\begin{array}{l}\text { Emura and } \\
\text { Okayasu (2003) }\end{array}$ & $\begin{array}{l}\text { Group social skill } \\
\text { education ( } 8 \text { sessions } \\
\text { over a half year, during } \\
\text { the period of integrated } \\
\text { studies) }\end{array}$ & $\begin{array}{l}\text { Social skills, subjective } \\
\text { adjustment (stress } \\
\text { response, school } \\
\text { stressors, social } \\
\text { support, sense of } \\
\text { loneliness, truancy } \\
\text { tendency) }\end{array}$ & $\begin{array}{l}133 \text { junior high school } \\
1 \text { st graders }\end{array}$ & $\begin{array}{l}\text { Quasi-experimental } \\
\text { design (without control } \\
\text { group) }\end{array}$ & $\begin{array}{l}\text { For those who had lower social skills } \\
\text { before the intervention and improved } \\
\text { their social skills after the intervention, } \\
\text { "sense of loneliness" declined and } \\
\text { "support from friends" increased. } \\
\text { Meanwhile, for those who had } \\
\text { moderate social skills before the } \\
\text { intervention and whose social skills } \\
\text { declined after the intervention, "bad } \\
\text { temper / anger" increased. }\end{array}$ \\
\hline $\begin{array}{l}\text { Fujieda and } \\
\text { Aikawa (2001) }\end{array}$ & $\begin{array}{l}\text { "Classwide Social } \\
\text { Skills Training" (CSST) } \\
10 \text { sessions, } 45 \\
\text { minutes each }\end{array}$ & $\begin{array}{l}\text { Self-evaluation of } \\
\text { social skills } \\
\text { (aggressiveness, pro- } \\
\text { sociality, shyness), } \\
\text { teacher evaluation of } \\
\text { social skills } \\
\text { (aggressiveness, pro- } \\
\text { sociality, shyness), } \\
\text { self-evaluation of } 5 \\
\text { target skills }\end{array}$ & $\begin{array}{l}63 \text { elementary school } \\
4 \text { th graders in } 2 \\
\text { classes }\end{array}$ & $\begin{array}{l}\text { Quasi-experimental } \\
\text { design }\end{array}$ & $\begin{array}{l}\text { There was no effect of CSST in self- } \\
\text { evaluation of social skills, when } 10 \\
\text { students with the lowest social skills } \\
\text { of each classroom were compared. } \\
\text { Meanwhile, among the target skills, } \\
\text { the control group improved their } \\
\text { "good way of requesting" and "warm } \\
\text { way of turning down" significantly } \\
\text { compared to the control group. For } \\
\text { teacher evaluation of social skills, } \\
\text { effects were found for all the three } \\
\text { factors. The results were similar when } \\
\text { the whole classrooms were } \\
\text { compared. }\end{array}$ \\
\hline
\end{tabular}




\section{Extra-curricular activities}

\begin{tabular}{|c|c|c|c|c|c|}
\hline Authors & Context measures & Skills measures & Study population & Study design & Main findings \\
\hline $\begin{array}{l}\text { Yamamoto, Araki } \\
\text { and Kamino } \\
(2010)\end{array}$ & Club participation & $\begin{array}{l}\text { Sociality, willingness to } \\
\text { engage in school } \\
\text { events and academic } \\
\text { learning }\end{array}$ & $\begin{array}{l}782 \text { high school } \\
\text { students }\end{array}$ & Cross-sectional design & $\begin{array}{l}\text { There was a significant relationship } \\
\text { between sociality and club } \\
\text { participation. In addition, those } \\
\text { participating in club activities were } \\
\text { more willing to engage than the non- } \\
\text { participating students in school events } \\
\text { and academic learning. }\end{array}$ \\
\hline Aoki (2005) & $\begin{array}{l}\text { Participation in athletic } \\
\text { club activities }\end{array}$ & $\begin{array}{l}\text { Social skills, self- } \\
\text { efficacy in athletic club } \\
\text { activities, self-efficacy }\end{array}$ & $\begin{array}{l}2709 \text { high school } \\
\text { students }\end{array}$ & Cross-sectional design & $\begin{array}{l}\text { There were main effects of club } \\
\text { affiliations, and the athletic club group } \\
\text { affiliation had higher social skills } \\
\text { scores than the non-affiliation group } \\
\text { and the cultural club group. Men had } \\
\text { higher social skill scores than women. } \\
\text { Moreover, self-efficacy and school } \\
\text { adjustment were correlated with } \\
\text { social skills. }\end{array}$ \\
\hline
\end{tabular}


EDU/WKP(2015)10

Improving school and classroom climate

\begin{tabular}{|c|c|c|c|c|c|}
\hline Authors & Context measures & Skills measures & Study population & Study design & Main findings \\
\hline $\begin{array}{l}\text { Udagawa and } \\
\text { Shimoda (2013) }\end{array}$ & $\begin{array}{l}\text { Perception of } \\
\text { classroom climate }\end{array}$ & $\begin{array}{l}\text { Assertion } \\
\text { ("aggressive," "non- } \\
\text { assertive," and } \\
\text { "assertive") }\end{array}$ & $\begin{array}{l}152 \text { elementary school } \\
5 \text { th graders and } 166 \\
\text { elementary school } 6 \text { th } \\
\text { graders }\end{array}$ & Cross-sectional design & $\begin{array}{l}\text { For both boys and girls, "assertive" } \\
\text { had a moderate positive correlation } \\
\text { with classroom satisfaction and a } \\
\text { weak negative correlation with } \\
\text { classroom disunity. Therefore, it is } \\
\text { indicated that when a student feels } \\
\text { comfortable with the classroom } \\
\text { atmosphere, their level of } \\
\text { assertiveness also increases. There } \\
\text { was no correlation between } \\
\text { "aggressive" or "non-assertive" and } \\
\text { classroom climate. }\end{array}$ \\
\hline $\begin{array}{l}\text { Takahashi, } \\
\text { Kawashima and } \\
\text { Yoshikawa (2010) }\end{array}$ & $\begin{array}{l}\text { Classroom satisfaction } \\
\text { (measured by Q-U) }\end{array}$ & Social skills & $\begin{array}{l}44 \text { elementary school } \\
\text { 4th graders }\end{array}$ & Longitudinal design & $\begin{array}{l}\text { Students who had higher satisfaction } \\
\text { with their classroom maintained high } \\
\text { social skills and influence other } \\
\text { students who have lower social skills } \\
\text { as models. }\end{array}$ \\
\hline $\begin{array}{l}\text { Komatsu and } \\
\text { Hida (2008) }\end{array}$ & $\begin{array}{l}\text { Evaluation of } \\
\text { classroom environment } \\
\text { (supportive } \\
\text { atmosphere, } \\
\text { affirmative group } \\
\text { environment, } \\
\text { disciplinary } \\
\text { environment, disturbing } \\
\text { atmosphere) }\end{array}$ & $\begin{array}{l}\text { Self-rated social skills } \\
\text { (basic skills for group } \\
\text { participation, active } \\
\text { relationship building } \\
\text { skills, self- } \\
\text { assertiveness) }\end{array}$ & $\begin{array}{l}184 \text { elementary school } \\
\text { 3rd graders }\end{array}$ & Cross-sectional design & $\begin{array}{l}\text { Those students who evaluated highly } \\
\text { "supportive atmosphere" classroom } \\
\text { environments tended to have higher } \\
\text { self-evaluation in all the sub-scales of } \\
\text { social skills. Those who evaluated } \\
\text { highly "affirmative group environment" } \\
\text { tend to have higher self-evaluation in } \\
\text { "active relationship building skills" and } \\
\text { "self-assertiveness," and those who } \\
\text { evaluated highly "disciplinary } \\
\text { environment" tend to have higher self- } \\
\text { evaluation in "basic skills for group } \\
\text { participation." }\end{array}$ \\
\hline
\end{tabular}


Experiencing volunteering activities

\begin{tabular}{|c|c|c|c|c|c|}
\hline Authors & Context measures & Skills measures & Study population & Study design & Main findings \\
\hline $\begin{array}{l}\text { Midzuno and Kato } \\
(2007)\end{array}$ & Volunteering activities & $\begin{array}{l}\text { Personality traits } \\
\text { (social extroversion } \\
\text { and dominance in Y-G } \\
\text { personality tests), } \\
\text { social skills (measured } \\
\text { by Kikuchi's Scale of } \\
\text { Social Skills (KiSS) - } \\
\text { 18) }\end{array}$ & 167 university students & Cross-sectional design & $\begin{array}{l}\text { Those who had experience in } \\
\text { volunteering activities had higher } \\
\text { social extroversion, dominance and } \\
\text { communication skills than those who } \\
\text { did not want to engage in volunteering } \\
\text { activities. However, those who wished } \\
\text { to engage in volunteering activities } \\
\text { also had higher social extroversion } \\
\text { and communication skills than those } \\
\text { who did not. Therefore, it is indicated } \\
\text { that those who tend to have higher } \\
\text { social extroversion and } \\
\text { communication skills tend to engage } \\
\text { in volunteering activities. }\end{array}$ \\
\hline $\begin{array}{l}\text { Baba, Shima and } \\
\text { Oya (2006) }\end{array}$ & $\begin{array}{l}\text { Volunteering activities } \\
\text { in the "Special Summer } \\
\text { Day Activities for } \\
\text { Children with } \\
\text { Disabilities" }\end{array}$ & $\begin{array}{l}\text { Social skills (especially } \\
\text { helping skills) }\end{array}$ & $\begin{array}{l}38 \text { college students } \\
\text { and general citizens } \\
\text { who participated in the } \\
\text { "Special Summer Day } \\
\text { Activities for Children } \\
\text { with Disabilities" }\end{array}$ & $\begin{array}{l}\text { Quasi-experimental } \\
\text { design (without control } \\
\text { group) }\end{array}$ & $\begin{array}{l}\text { Self-evaluation of social skills } \\
\text { increased after the volunteering } \\
\text { activities. }\end{array}$ \\
\hline
\end{tabular}


EDU/WKP(2015)10

Outdoor adventure programmes

\begin{tabular}{|c|c|c|c|c|c|}
\hline Authors & Context measures & Skills measures & Study population & Study design & Main findings \\
\hline $\begin{array}{l}\text { National } \\
\text { Institution for } \\
\text { Youth and } \\
\text { Education (2010) }\end{array}$ & $\begin{array}{l}\text { Experience in the } \\
\text { community during } \\
\text { childhood (experience } \\
\text { in nature, contact with } \\
\text { animals and plants, } \\
\text { playing with friends, } \\
\text { community activities, } \\
\text { family events and } \\
\text { helping with } \\
\text { housework) }\end{array}$ & $\begin{array}{l}\text { "Skills of experience" } \\
\text { (self-esteem, sense of } \\
\text { living together, } \\
\text { motivation/interest, } \\
\text { normative } \\
\text { consciousness, } \\
\text { interpersonal skills, } \\
\text { work consciousness } \\
\text { and manners/culture) }\end{array}$ & $\begin{array}{l}2844 \text { high school } 2 \text { nd } \\
\text { graders and } 5000 \\
\text { adults aged from } 20 \text { to } \\
60 \text { years old }\end{array}$ & $\begin{array}{l}\text { Longitudinal design } \\
\text { using retrospective } \\
\text { surveys }\end{array}$ & $\begin{array}{l}\text { Analysis of self-reports by adults and } \\
\text { high school students about their } \\
\text { childhood experiences indicates that } \\
\text { "skills of experience" is related with } \\
\text { "play with friends" and "contact with } \\
\text { animals and plants" during the lower } \\
\text { grades of elementary school and with } \\
\text { "community activities," "family events" } \\
\text { and "help with housework" during the } \\
\text { upper grades through junior high } \\
\text { school. }\end{array}$ \\
\hline $\begin{array}{l}\text { Araki, Okamura } \\
\text { and Hamatani } \\
\text { (2007) }\end{array}$ & $\begin{array}{l}\text { Activities to encourage } \\
\text { participants' reflection } \\
\text { during a six-day } \\
\text { adventure camp }\end{array}$ & $\begin{array}{l}\text { Leadership, } \\
\text { interpersonal skills, } \\
\text { attitudes towards } \\
\text { personal growth }\end{array}$ & 14 college students & $\begin{array}{l}\text { Quasi-experimental } \\
\text { design } \\
\text { Assessment was } \\
\text { conducted before, after } \\
\text { and two-months after } \\
\text { the six-day adventure } \\
\text { camp. }\end{array}$ & $\begin{array}{l}\text { The treatment group's leadership } \\
\text { score significantly increased two } \\
\text { months after the camp compared to } \\
\text { before the camp, while no change } \\
\text { was observed among the control } \\
\text { group. }\end{array}$ \\
\hline
\end{tabular}


EDU/WKP(2015)10

\begin{tabular}{|c|c|c|c|c|c|}
\hline Authors & Context measures & Skills measures & Study population & Study design & Main findings \\
\hline $\begin{array}{l}\text { Yasunami et al. } \\
(2006)\end{array}$ & $\begin{array}{l}\text { Programme types of a } \\
\text { nature school (e.g. } \\
\text { "outdoor cooking," "arts } \\
\text { and craft," "recreational } \\
\text { programme," "free } \\
\text { choice programme") }\end{array}$ & $\begin{array}{l}\text { Social and emotional } \\
\text { development } \\
\text { (measured by the } \\
\text { Evaluation Scale of } \\
\text { Nature-Experience } \\
\text { Programs) }\end{array}$ & $\begin{array}{l}1126 \text { elementary } \\
\text { school } 5 \text { th graders } \\
\text { from } 14 \text { schools }\end{array}$ & $\begin{array}{l}\text { Quasi-experimental } \\
\text { design (without control } \\
\text { group) }\end{array}$ & $\begin{array}{l}\text { Participating students' social and } \\
\text { emotional development improved } \\
\text { significantly immediately after the } \\
\text { nature school, and was maintained } \\
\text { after one month. In particular, } \\
\text { students of those schools that } \\
\text { included the programme "outdoor } \\
\text { cooking" improved judgment and } \\
\text { leadership significantly more than } \\
\text { students of the schools that did not } \\
\text { include the programme. Similarly, } \\
\text { students of those schools that } \\
\text { included "free choice programme" } \\
\text { tended to improve interpersonal skills } \\
\text { and sensibility to nature after the } \\
\text { nature school and maintained them } \\
\text { after one month. On the other hand, } \\
\text { students in the schools that included } \\
\text { "recreational programme" improved } \\
\text { social and emotional development } \\
\text { less than students in the schools that } \\
\text { did not include the programme. }\end{array}$ \\
\hline $\begin{array}{l}\text { Nakagawa et al. } \\
(2005)\end{array}$ & $\begin{array}{l}\text { Lon-term camping } \\
\text { lasting } 15 \text { days and } \\
\text { short-term camping } \\
\text { lasting } 3 \text { days }\end{array}$ & $\begin{array}{l}\text { "Zest for Living" } \\
\text { (measured by the IKR } \\
\text { Inventory) }\end{array}$ & $\begin{array}{l}54 \text { children, elementary } \\
\text { school } 4 \text { th graders to } \\
\text { junior high school } 3 \text { rd } \\
\text { graders }\end{array}$ & $\begin{array}{l}\text { Quasi-experimental } \\
\text { design (without control } \\
\text { group) } \\
\text { Comparison between } \\
\text { the long-term camping } \\
\text { participants and the } \\
\text { short-term camping } \\
\text { participants of } \\
\text { assessment of skills } \\
\text { before, after and one } \\
\text { month after each of the } \\
\text { camping programmes. }\end{array}$ & $\begin{array}{l}\text { For those who enrolled in the long- } \\
\text { term camping, the subscales } \\
\text { "judgment" and "concern with nature" } \\
\text { significantly increased after the } \\
\text { camping and were maintained one } \\
\text { month after the camping. Those who } \\
\text { enrolled in the short-term camping } \\
\text { showed an increase in the subscale } \\
\text { "cheerfulness" only immediately after } \\
\text { the camping, and in "friendship and } \\
\text { cooperation" only one month after the } \\
\text { camping. }\end{array}$ \\
\hline Ihara et al. (2004) & $\begin{array}{l}\text { Adventure educational } \\
\text { programme }\end{array}$ & General self-efficacy & $\begin{array}{l}17 \text { children, elementary } \\
\text { school } 4 \text { th graders to } \\
\text { junior high school } 3 \text { rd } \\
\text { graders }\end{array}$ & $\begin{array}{l}\text { Quasi-experimental } \\
\text { design (without control } \\
\text { group) }\end{array}$ & $\begin{array}{l}\text { General self-efficacy of the adventure } \\
\text { educational programme's participants } \\
\text { increased significantly one month } \\
\text { after the programme compared to } \\
\text { before the programme participation. }\end{array}$ \\
\hline
\end{tabular}

